\title{
COMBINAÇÃO DE DOSES DE NITROGÊNIO E POTÁSSIO NA NUTRIÇÃO MINERAL DE CAPIM-BRAQUIÁRIA
}

\author{
María del Carmen Ferragine \\ Engenheira Agrônoma
}

Orientador: Prof. Dr. FRANCISCO ANTONIO MONTEIRO

\footnotetext{
Dissertação apresentada à Escola Superior de Agricultura "Luiz de Queiroz", Universidade de São Paulo, para obtenção do título de Mestre em Agronomia, Área de Concentração: Solos e Nutrição de Plantas.
}

\section{PIRACICABA}

Estado de São Paulo - Brasil

Dezembro - 1998 
Dados Internacionais de Catalogação na Publicação (CIP)

DIVISÃO DE BIBLIOTECA E DOCUMENTAÇĀO - Campus "Luiz de Queiroz"/USP

\section{Ferragine, María del Carmen}

Combinaçōes de doses de nitrogênio e potássio na nutrição mineral de capimbraquiária / María del Carmen Ferragine. - Piracicaba, 1998.

84 p. : il.

Dissertação (mestrado) - - Escola Superior de Agricultura Luiz de Queiroz, 1998. Bibliografia.

1. Capim braquiária 2. Composiçăo química 3. Graminea forrageira 4. Interaçăo 5. Matéria seca 6. Nitrogênio 7. Perfilhação 8. Potássio 9. Silica 10. Solução nutritiva 11. Substrato I. Título 
Aos meus pais

NORA e CARLOS

A minha irmã e meu cunhado

MÓNICA e JORGE

A minha tia

ENRIQUETA

pelo amor, apoio e incentivo

OFEREÇO E DEDICO 


\section{AGRADECIMENTOS}

Ao Prof. Dr. Francisco Antonio Monteiro pela excelente orientação, pelo apoio e principalmente pela amizade desenvolvida.

Ao Prof. Dr. Quirino Augusto de Camargo Carmello, pela amizade, atenção, ajuda e sugestões.

Ao Prof. Dr. Antonio Roque Dechen, pela amizade e constante incentivo.

A todos os professores do Curso de Solos e Nutrição de Plantas, pela dedicação e conhecimentos transmitidos.

Aos estagiários de Nutrição Mineral de Plantas Celso Pedroso Faria Israel Benetti, José Lavres Junior e Pelerson Furlan Schiavuzzo pela ajuda, dedicação e amizade.

Aos funcionarios do Laboratório de Nutrição Mineral de Plantas Alexandre de Oliveira, Edinéia Cristina Scervino Mandoni, Lúcia Helena S. P. Forti, Lurdes Aparecida Dário de González, Mirtes Ventura Sesso, Nivanda Maria de Moura e Sueli Maria Amaral Campos Bovi pelo apoio à realização das análises.

A Giovana Maria de Oliveira pela amizade e ajuda na confecção dos gráficos e configuração do texto.

Ao pessoal da Biblioteca Central da ESALQ, em especial Eliana Maria Garcia Sabino pelas correções de referências bibliográficas, Kátia Maria de Andrade Ferraz e Luzia Fátima dos Santos Possatto pela ajuda permanente.

Às famílias Ferragine: Francisco, Josefina e Ethel; Wenger: Mary, Ernesto e Jorge, pelo carinho e apoio constante; Alves: Diva, Rosa Lúcia e Iza, pela atenção e carinho numa fase muito importante da minha estadia em Piracicaba: o inicio.

Aos amigos João Batista, Silvia, Cristián e Linda Monica pelo carinho, apoio, incentivo e ajuda na realização deste trabalho.

Aos companheiros de sala de Nutrição Mineral de Plantas João Batista, Fábio, Alberto, César, Jonas, Reynaldo, Carla ,Waldssimiler, Linda 
Monica, Cirlene, Monica, Glaucia, Walcilene pelo apoio, incentivo e momentos compartidos.

Aos amigos Rosa, Gabriela, Pablo, Marisa, Luciana, Nilvia, Ireni, Adriano e Cristiane pelo carinho e apoio constante.

Aos amigos de Argentina e a Deus que, apesar de não estarem a nossa vista, estão sempre próximos.

À CAPES Fundação Coordenação de Aperfeiçoamento de Pessoal de Nivel Superior e Ministerio de Cultura y Educación, Secretaría de Políticas Universitárias Argentinas pela concessão de bolsa de estudos.

À Facultad de Ciencias Veterinarias, Universidad Nacional de La Plata, em especial à Dra. Liliana Lagreca e aos Cursos de Zootecnia General e Zootecnia I. À Facultad de Ciencias Agrarias e Forestales, Universidad Nacional de La Plata, em especial ao Curso de Forrajicultura pelo incentivo e oportunidade concedida para realização deste curso. 


\section{SUMÁRIO}

Página

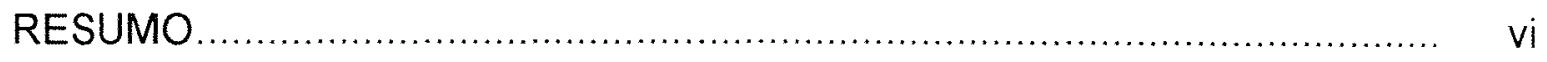

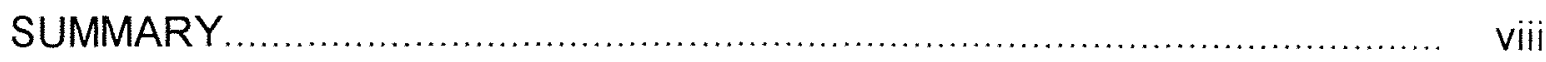

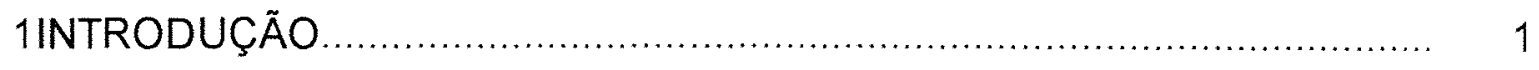

2 REVISÃO DE LITERATURA ............................................................ 3

2.1 A espécie Brachiaria decumbens Stapf............................................. 3

2.2 Nitrogênio em gramíneas forrageiras ................................................ 4

2.3 Potássio em gramíneas forrageiras ........................................... 10

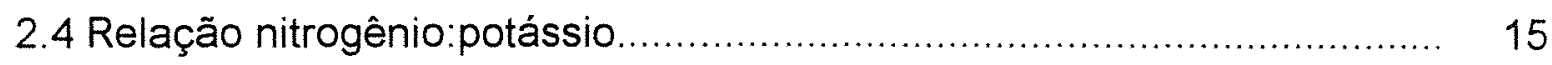

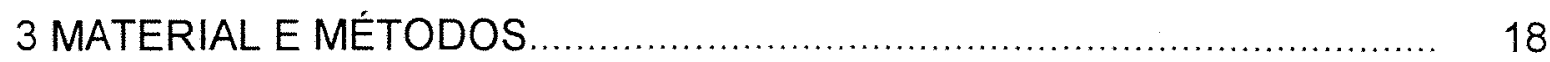

3.1 Local, período e espécie forrageira ................................................ 18

3.2 Tratamentos, soluções nutritivas, e delineamento experimental............. 18

3.3 Instalação e condução do experimento ............................................. 19

3.4 Determinação do número de perfilhos e coleta do material vegetal ........ 20

3.5 Produção de matéria seca............................................................... 21

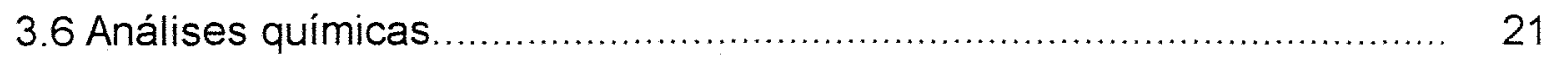

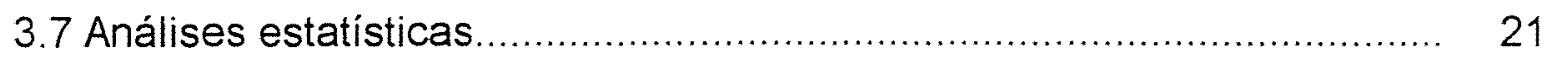

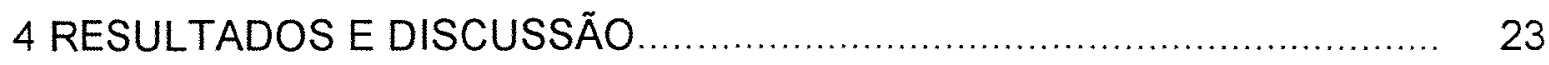

4.1 Produção de matéria seca.......................................................... 23

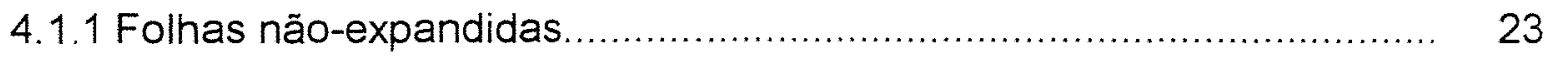


4.1.2 Lâminas de folhas novas............................................................... 25

4.1.3 Lâminas de folhas velhas.......................................................... 28

4.1.4 Colmos mais bainhas............................................................ 30

4.1.5 Produção de matéria seca da parte aérea......................................... 33

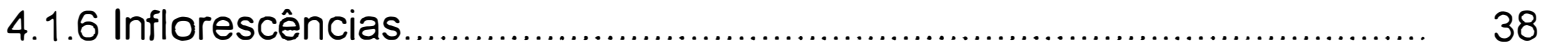

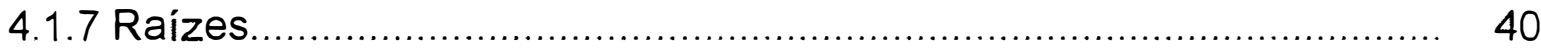

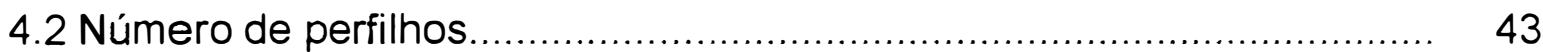

4.3 Concentração dos macronutrientes nas lâminas de folhas novas........... 50

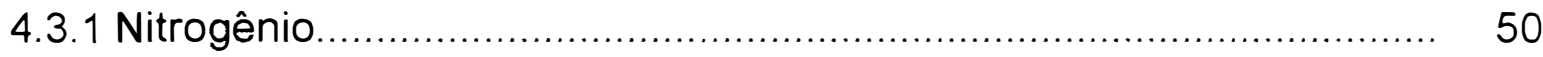

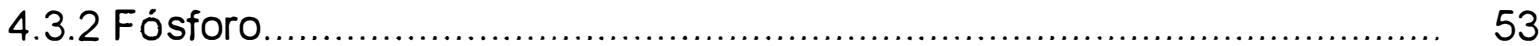

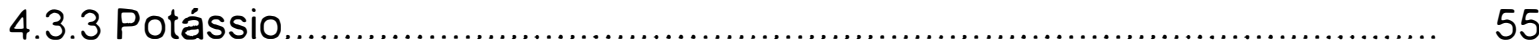

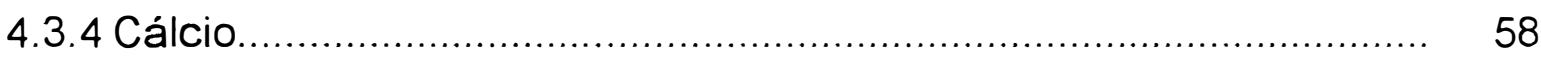

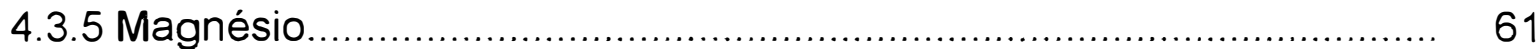

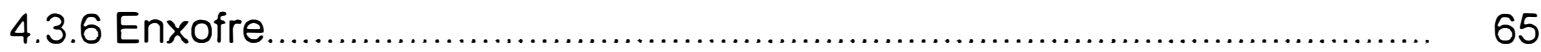

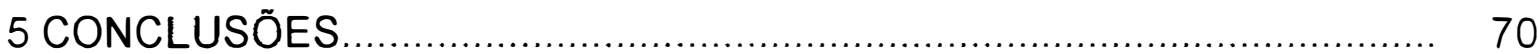

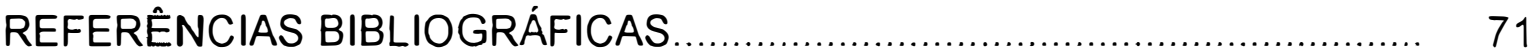




\title{
COMBINAÇÃO DE DOSES DE NITROGÊNIO E POTÁSSIO NA NUTRIÇÃO MINERAL DE CAPIM-BRAQUIÁRIA
}

\author{
Autora: MARIA DEL CARMEN FERRAGINE
}

Orientador: Prof. Dr. FRANCISCO ANTONIO MONTEIRO

\section{RESUMO}

Foi conduzido um experimento em casa-de-vegetação com o capimbraquiária (Brachiaria decumbens Stapf. cv. Basilisk), cultivado em solução nutritiva, utilizando sílica como substrato, no período de outubro de 1997 a fevereiro de 1998. Empregou-se um esquema fatorial $5 \times 3$ (cinco doses de nitrogênio e três doses de potássio) perfazendo um total de 15 combinações, as quais foram distribuidas segundo o delineamento experimental de blocos completos ao acaso, com quatro repetições. Foram utilizadas cinco doses de nitrogênio (42; 140; 238; 336 e $\left.434 \mathrm{mg} \mathrm{L}^{-1}\right)$ em combinação com três doses de potássio $\left(78 ; 234\right.$ e $\left.390 \mathrm{mg} \mathrm{L}^{-1}\right)$, com objetivo de avaliar os efeitos na produção de matéria seca da parte aérea toda e dos seus componentes (folhas nãoexpandidas, lâminas de folhas novas, lâminas de folhas velhas $e$ colmos+bainhas), na massa radicular, no perfilhamento e na composição mineral da folha diagnóstica desta forrageira. O primeiro corte das plantas ocorreu 43 dias após o transplante das mudas para os vasos e o segundo corte aos 30 dias após o primeiro corte.

Os resultados evidenciaram que a interação entre nitrogênio e potássio na produção de matéria seca da parte aérea da Brachiaria decumbens foi significativa $(P<0,01)$ nos componentes da planta: lâminas de folhas novas, colmos mais bainhas e matéria seca da parte aérea no primeiro crescimento e 
$(P<0,05)$ nas lâminas de folhas novas no segundo crescimento. As máximas produções de matéria seca da parte aérea foram obtidas com potássio em 155 $\mathrm{mg} \mathrm{L}^{-1}$ quando o nitrogênio foi de $42 \mathrm{mg} \mathrm{L}^{-1}$ e $222 \mathrm{mg} \mathrm{KL}^{-1}$ quando o nitrogênio foi suprido em $238 \mathrm{mg} \mathrm{L}^{-1}$ na solução nutritiva.

$\mathrm{Na}$ produção de folhas não-expandidas, lâminas de folhas velhas, inflorescências e raízes não foi significativa $(P>0,05)$ a interação entre nitrogênio e potássio, mas houve significância $(P<0,01)$ para as doses de nitrogênio, em ambos os crescimentos. O efeito das doses de potássio na produção de matéria seca resultou em significância $(P<0,05)$ na produção das lâminas de folhas novas e das lâminas de folhas velhas no primeiro crescimento e nas raízes.

A interação entre doses de nitrogênio e de potássio foi significativa $(P<0,05)$ para a concentração de nitrogênio nas lâminas de folhas novas tanto no primeiro como no segundo crescimento. No estudo das doses de nitrogênio dentro de cada dose de potássio somente houve significância para o nitrogênio $(P<0,05)$ dentro da dose $234 \mathrm{mg} \mathrm{L}^{-1}$ de potássio. Na concentração de nitrogênio observou-se significância $(P<0,01)$ para as doses de potássio dentro da dose $238 \mathrm{mg} \mathrm{L}^{-1}$ de nitrogênio, no primeiro crescimento.

A concentração de potássio nas lâminas de folhas novas revelou que não foi significativa $(P>0,05)$ a interação entre doses de nitrogênio e de potássio. As doses de nitrogênio influenciaram significativamente $(P<0,01)$ na concentração de potássio nas lâminas da braquiária, em ambos os períodos de crescimento. A concentração de potássio nas lâminas de folhas novas aumentou em função das doses de potássio, para ambos períodos de crescimento.

Também nas concentrações de fósforo, cálcio, magnésio e enxofre na forrageira ocorreram significâncias para a interação entre doses de nitrogênio e de potássio na solução nutritiva. 


\title{
MINERAL NUTRITION OF Brachiaria decumbens GROWN WITH COMBINATIONS OF NITROGEN AND POTASSIUM RATES.
}

\author{
Author: MARIA DEL CARMEN FERRAGINE
}

Adviser: Prof. Dr. FRANCISCO ANTONIO MONTEIRO

\section{SUMMARY}

A greenhouse experiment was carried out with Brachiaria decumbens Stapf. cv. Basilisk grown in nutrient solution by using ground quartz as substrate. Plants were grown from mid-spring to mid-summer. A $5 \times 3$ factorial (five nitrogen rates and three potassium rates) in a randomized complete block design, with four replications, was used. Nitrogen rates were $42 ; 140 ; 238 ; 336$ and $434 \mathrm{mg} \mathrm{L}^{-1}$ whereas potassium rates were $78 ; 234$ and $390 \mathrm{mg} \mathrm{L}^{-1}$. Plant tops and their parts (non-expanded leaves, young leaf blades, old leaf blades and culms + sheaths), dry matter yield, roots dry weight, plant tillering and plant mineral composition. Plants were harvested twice at: 43 days after seedling transplanting to pots and 30 days after the first harvest.

The results showed that the nitrogen $x$ potassium interaction was significant $(P<0.01)$ for the wole or parts of plant tops yield in the first harvest and also $(P<0.05)$ for the young leaves was reached when the nutrient solution had $155 \mathrm{mg} \mathrm{L}^{-1}$ potassium and $42 \mathrm{mg} \mathrm{L}^{-1}$ nitrogen or $222 \mathrm{mg} \mathrm{L}^{-1}$ potassium and $238 \mathrm{mg} \mathrm{L}^{-1}$ nitrogen.

Nitrogen $x$ potassium interaction was not significant $(P>0.05)$ for nonexpanded leaves, old leaf blades, inflorescences and roots dry weight. These plant parameters significantly $(P<0.01)$ changed with nitrogen rates, whereas young leaf blades, old leaves blades and roots dry weight in the first harvest changed $(P<0.05)$ with potassium rates in the nutrient solution. 
The interaction nitrogen $x$ potassium was significant $(P<0.05)$ for nitrogen concentration in young leaf blades sampled at the first and second harversts, but was not significant $(P>0.05)$ for potassium concentration in this plant tissue. Nitrogen rates promoted changes in nitrogen concentration in young leaf blades when potassium was at $234 \mathrm{mg} \mathrm{L}^{-1}$ in the solution, whereas potassium rates had significant effect when $238 \mathrm{mg} \mathrm{L}^{-1}$ nitrogen was in the solution. Potassium concentration in young leaf blades sampled in both harversts changed with nitrogen rates and was increased by potassium rates in the nutrient solution.

Nitrogen $x$ potassium interaction also had significant effects on phosphorus, calcium, magnesium and sulfur concentration in young leaf blades of this forage grass. 


\section{INTRODUÇÃO}

A produção animal nas condições brasileiras é sustentada basicamente em pastagens. A maior ênfase no potencial produtivo das forrageiras redunda em uma melhora nos indices de produtividade animal, e consequentemente na importância econômica do sistema produtivo em geral, pois o fornecimento de forragem constitui a base dos sistemas de produção dos herbivoros.

As pastagens cultivadas nas regiões tropicais mostram com frequência uma queda de produtividade após alguns anos de seu estabelecimento, devido principalmente ao manejo inadequado do solo.

Diversas são as espécies de gramineas forrageiras tropicais que apresentam-se como opções para compor as pastagens no Brasil. Entre elas, as gramineas do gênero Brachiaria adaptam-se a variadas condições de solo e clima, mas a sua expansão nas condições do Brasil Central foi relacionada principalmente a sua adaptação a condições de solos com baixa a média fertilidade, onde proporcionam produções satisfatórias de forragem.

Apesar de as braquiárias serem cultivadas em grandes áreas no Brasil Central, existe uma grande carência nos estudos sobre práticas de manejo como também sobre a nutrição mineral das mesmas.

O conhecimento dos fatores nutricionais limitantes ao crescimento das gramíneas forrageiras é de grande importância para a formação, manejo e persistência das forrageiras nas pastagens cultivadas. Dentre os fatores de produção, o nitrogênio é considerado um dos nutrientes minerais mais relevantes. 
A distribuição do nitrogênio nas plantas, tomada isoladamente, depende de suas características genéticas, que são variáveis dentro e entre espécies. Em virtude das folhas serem a parte de primeira oferta aos herbivoros, sua composição química adquire importância especial, como superfície de captação da energia solar ou pela sua participação no valor nutritivo da forragem.

Nas áreas dedicadas a pastagens no Brasil Central não tem sido generalizada a ocorrência de baixos ou muito baixos teores de potássio trocável no solo, mas quando a aplicação de nitrogênio é considerada nessas áreas, o suprimento de potássio passa a ter importância realçada.

A passagem dos nutrientes através do organismo animal constitui uma importante via na reciclagem desses nutrientes no sistema da pastagem, dependendo da proporção de nutrientes reciclada por essa via, da quantidade de forragem utilizada pelos animais, como também da composição química das partes das plantas que são consumidas

O estudo de processos metabólicos na braquiária abrangendo 0 nitrogênio e o potássio deve contribuir para um melhor conhecimento da produtividade potencial dessa forrageira.

O objetivo desse trabalho foi de avaliar a Brachiaria decumbens Stapf. cv. Basilisk quanto à produção de matéria seca da parte aérea e raizes, perfilhamento e composição quimica desta forrageira, em termos da influência das doses de nitrogênio e de potássio, com especial ênfase para a interação entre esses dois nutrientes. 


\section{REVISÃO DE LITERATURA}

\subsection{A espécie Brachiaria decumbens Stapf.}

As espécies do gênero Brachiaria Griseb têm sua distribuição nas regiões tropicais de ambos os hemisférios do globo, ocorrendo principalmente nas savanas africanas. No Brasil encontram-se cerca de 16 espécies deste gênero, sendo que sete foram introduzidos recentemente (principalmente da África), as quais vêm sendo cultivadas como forrageiras.

A Brachiaria decumbens Stapf. é uma espécie perene que ocorre de forma nativa no leste tropical da África (do Equador aos paralelos $30^{\circ} \mathrm{N}$ e S), sob clima moderadamente úmido, acima de 800 metros de altitude, em pastagens abertas ou em áreas com arbustos esporádicos (Bogdan, 1977). O cultivar Basilisk foi trazido para São Paulo em 1970, proveniente da Austrália, mas é de origem africana (Alcântara, 1986).

Segundo Rocha (1985), num levantamento realizado em conjunto pelo Instituto Agronômico e pelo Instituto de Zootecnia, a Brachiaria decumbens, na década de 80 ocorria em $92 \%$ dos municípios do Estado de São Paulo. Por outro lado, Zimmer et al. (1994) estimaram que a área de pastagem formada com braquiárias no Brasil estava em torno de 60 milhões de hectares. A braquiária têm bom potencial de produção de forragem em solos férteis ou adubados, possui alta agressividade e elevada disseminação pela semeadura natural. 
O hábito de crescimento desta forrageira é prostrado, emitindo raizes e novos brotos das gemas axilares bem como das gemas basais. As folhas são do tipo lanceolada ou linear-lanceolada, com 10 a 15 centímetros de comprimento e 1 a 1.5 centímetros de largura, macias e densamente pilosas (Mitidieri, 1988).

\subsection{Nitrogênio em gramíneas forrageiras}

O conhecimento dos fatores nutricionais limitantes ao crescimento das gramíneas forrageiras é de grande importância para a formação, manejo e persistência das pastagens cultivadas. Dentre os fatores de produção, o nitrogênio é considerado um dos nutrientes de alta contribuição, pois constitui o principal nutriente para a manutenção da produtividade das gramíneas forrageiras.

O nitrogênio participa ativamente na síntese dos compostos orgânicos que formam a estrutura vegetal (Malavolta, 1980; Mengel \& Kirkby, 1987), sendo responsável por características das plantas tais como: aparecimento e desenvolvimento dos perfilhos, tamanho das folhas e do colmo (Davies, 1974; Nabinger 1997). Portanto, se houver baixa disponibilidade de nitrogênio no solo, as plantas manifestarão menor crescimento, diminuindo a quantidade dos perfilhos e de folhas, com a conseguinte diminuição do teor de proteína bruta, de forma a tornar a forrageira deficiente para atender as necessidades do animal que a ingere.

O nitrogênio é um macronutriente cuja importância tem sido realçada, tanto no uso de fertilizantes em nível mundial, como em conteúdo nas culturas e nas colheitas (Raij, 1991).

O nitrato e o amônio são as formas de nitrogênio mais absorvidas pelas raizes e transportadas no xilema das plantas superiores. Parte do amônio é incorporado em compostos orgânicos nas próprias raízes, enquanto o nitrato 
é reduzido a amônio para fazer parte dos esqueletos carbônicos das plantas. $\mathrm{O}$ nitrato é muito móvel na planta e pode também ser armazenado nos vacúolos das células das raízes, colmos e órgãos de reserva (Marschner, 1995).

$\rightarrow$ A adubação nitrogenada para as gramíneas tropicais vem sendo estudada há várias décadas. Vicente-Chandler (1973) abordou o efeito de doses de nitrogênio em sete capins tropicais e relatou uma ampla faixa de resposta em produção de matéria seca à aplicação de nitrogênio, tendo o capim-gordura (Melinis minutiflora Beauv.) seu máximo de produção na dose de nitrogênio de $224 \mathrm{~kg} \mathrm{ha}^{-1} \mathrm{ano}^{-1}$, enquanto para o capim-Napier (Pennisetum purpureum Schum.) a máxima produção ocorreu na dose $1792 \mathrm{~kg} \mathrm{ha}^{-1} \mathrm{ano}^{-1}$.

Werner et al. (1967), utilizando capim-colonião (Panicum maximum Jacq.), verificaram que depois da adubação fosfatada, a nitrogenada foi a grande limitação para o desenvolvimento inicial dessa forrageira, tanto em termos de produção de matéria seca como de perfilhamento da mesma planta. Monteiro \& Werner (1977) comprovaram essa importância do nitrogênio após o atendimento da demanda inicial por fósforo para essa espécie forrageira. Harding \& Grof (1978), estudando níveis de nitrogênio em Brachiaria decumbens, constataram como ótimo a dose de $365 \mathrm{~kg} \mathrm{ha}^{-1} \mathrm{ano}^{-1}$, em termos de produção de matéria seca e aproveitamento de nitrogênio.

Segundo Corsi (1984), a adubação nitrogenada favorece o número e o peso de perfilhos e estimula 0 alongamento do caule em capim-colonião. Mazzanti et al. (1994) estudaram os efeitos da aplicação dos niveis de nitrogềnio em Festuca arundinacea $\mathrm{cv}$. Clarine e cv. Barcel e verificaram que as aplicações de nitrogênio incrementaram a densidade dos perfilhos em $22 \%$ para Clarine e $20 \%$ para Barcel Nabinger (1997) relatou que a adequada disponibilidade de nitrogênio exerce efeitos positivos na taxa de aparecimento de perfilhos, mas altas disponibilidades deste elemento podem determinar uma menor densidade de perfilhos devido ao mais rápido desenvolvimento do índice de área foliar e ao aumento na mortalidade dos perfilhos. 
Sanzonowicz (1986) relatou que em pastagens estabelecidas há mais de cinco anos o principal nutriente a limitar a produção das pastagens de Brachiaria ruziziensis e Brachiaria decumbens era o nitrogênio.

Soares Filho et al. (1992) verificaram que a adubação com macro, incluindo nitrogênio, e micronutrientes e representou efeito benéfico na recuperação da pastagem e na produção de matéria seca da parte aérea e raízes de Brachiaria decumbens, enquanto que o tratamento mecânico com grade afetou negativamente a recuperação dessa espécie. Arruda et al. (1987) relataram que a aplicação de tratamento mecânico sem fertilização não melhorou a recuperação de pastagens de Brachiaria decumbens.

Monteiro et al. (1980), em um experimento realizado com adubação potássica aplicada ao capim-colonião, constataram que houve aumento na produção de matéria seca, na proteína total anual e no teor de proteína no capim mediante $o$ aumento da dose de adubo nitrogenado, independentemente da adubação potássica.

Favoretto et al. (1988) aplicaram nitrogênio ao solo nas doses de 0 , 50 e $100 \mathrm{~kg} \mathrm{ha}^{-1}$ cultivado com capim-colonião, avaliaram as respostas no verão (novembro-março) e constataram significativo aumento na produção de matéria seca com os incrementos das doses desse nutriente.

Trabalhando com Brachiaria decumbens e Brachiaria brizantha em Latossolo Vermelho-Amarelo, Alvim et al. (1990) verificaram que todos os acessos de Brachiaria estudados responderam a $150 \mathrm{~kg} \mathrm{ha}^{-1}$ de nitrogênio e que na dose de $75 \mathrm{~kg} \mathrm{ha}^{-1}$ não obtiveram diferenças na produção de matéria seca nos acessos de Brachiaria decumbens e Brachiaria brizantha. Na não aplicação de nitrogênio os acessos de Brachiaria decumbens foram mais produtivos que os demais.

Ao abordarem as respostas de gramíneas forrageiras à adubação nitrogenada, Carvalho et al. (1991) constataram incrementos marcantes na produção de matéria seca da Brachiaria decumbens quando foi submetida até 
a dose de nitrogênio de $400 \mathrm{~kg} \mathrm{ha}^{-1} \mathrm{ano}^{-1}$. Hoffmann (1992) verificou a máxima produção na Brachiaria decumbens na dose de nitrogênio de $437 \mathrm{mg} \mathrm{kg}^{-1}$ de solo. Pietrosemoli et al. (1996) observaram as maiores produções de matéria seca da Brachiaria brizantha quando o nitrogênio foi empregado em $400 \mathrm{~kg} \mathrm{ha}^{-1} \mathrm{ano}^{-1}$.

Os níveis de nitrogênio utilizados em solução nutritiva proporcionaram, como demonstrou Abreu (1994), aumentos no número de perfilhos, na produção de matéria seca da parte aérea e na concentração de nitrogênio total na matéria seca da parte aérea e das raízes, em Panicum maximum Jacq. cv. Tanzânia-1, Brachiaria brizantha Stapf cv. Marandu $e$ Melinis minutiflora Beauv.

Santos (1997), estudando a diagnose nutricional e respostas do capim-braquiária submetido a doses de nitrogênio e de enxofre, comprovou que a concentração de nitrogênio de $210 \mathrm{mg} \mathrm{L}^{-1}$ na solução nutritiva, como apontada no tratamento completo da solução de Sarruge (1975), não é suficiente para a expressão do máximo potencial produtivo dessa forrageira. Verificou também que 0 aumento das doses de nitrogênio e de enxofre na solução proporcionaram aumentos na produção de matéria seca da parte aérea e das raizes desse capim.

Dias et al. (1998) cultivaram, em um Latossolo Vermelho-Escuro distrófico que recebeu quatro doses de $N\left(0,100,200\right.$ e $400 \mathrm{~kg} \mathrm{ha}^{-1}$, na forma de sulfato de amônio), os capins transvala (Digitaria decumbens Stent cv. Transvala), suázi (Digitaria swazilandensis Stent) e coastcross (Cynodon dactylon L.Pers cv. Coastal x Cynodon nlemfuensis var. robustus). Constataram que a adubação nitrogenada proporcionou aumento no rendimento de matéria seca dos capins e que a dose de $100 \mathrm{~kg} \mathrm{ha}^{-1}$ de nitrogênio mostrou a maior eficiência de utilização desse nutriente.

Trabalhando no solo Cambissolo álico da microregião Campos de Mantiqueira, com omissão de nutrientes nos capins Brachiaria brizantha e 
Andropogon gayanus, Faquin et al. (1995a) verificaram que os tratamentos que mais limitaram o crescimento das forrageiras foram a omissão de nitrogênio, fósforo e potássio. Monteiro et al. (1995) observaram em Brachiaria brizantha Stapf. cv. Marandu cultivada em solução nutritiva que as omissões de nitrogênio e fósforo limitaram o crescimento, ao passo que a omissão de potássio não afetou a produção de matéria seca e número de perfilhos.

Em virtude das folhas serem as partes de primeira oferta aos herbivoros, sua composição química adquire importância especial, como superfície de captação da energia solar ou pela sua participação no valor nutritivo. A qualidade e a aceitação de forragem diminuem à medida que as forrageiras amadurecem e alcançam as fases de florescimento e frutificação (Blaser et al. ,1986).

Um dos parâmetros utilizados para avaliar o valor nutritivo das plantas forrageiras é a concentração de proteina bruta no tecido vegetal. Bredon \& Horell (1962) relataram variação no teor de proteína bruta de 52 a 75 $\mathrm{g} \mathrm{kg}^{-1}$ na Brachiaria decumbens e de 42 a $75 \mathrm{~g} \mathrm{~kg}^{-1}$ na Brachiaria brizantha. Milford \& Minson (1965) observaram, nas forrageiras tropicais, que teores de proteína bruta abaixo de $70 \mathrm{~g} \mathrm{~kg}^{-1}$ estariam limitando o consumo de matéria seca pelos animais.

Fernandes et al. (1985) observaram em Brachiaria decumbens que doses de nitrogênio de 0 e $40 \mathrm{~kg} \mathrm{ha}^{-1}$ resultaram em baixas concentrações de nitrogênio na parte aérea de 7,8 e $9,0 \mathrm{~g} \mathrm{~kg}^{-1}$, respectivamente. Carvalho et al. (1991) verificaram valores baixos de concentração de nitrogênio na parte aérea da Brachiaria decumbens (em torno de 14 a $21 \mathrm{~g} \mathrm{~kg}^{-1}$ ) e que nos tratamentos com altos níveis de adubação ocorriam maiores produções de matéria seca em detrimento de uma redução nas concentrações de nitrogênio, evidenciando um efeito de diluição.

Marques et al. (1995) avaliando as limitações nutricionais no braquiarão (Brachiaria brizantha cv. Marandu) e andropogon (Andropogon 
gayanus cv. Planaltina) cultivados em Cambissolo álico da microrregião Campos da Mantiqueira, constataram que os tratamentos que afetaram o perfilhamento e a produção de matéria seca da parte aérea das forrageiras foram as omissões de fósforo, nitrogênio e potássio.

Corrêa et al. (1996), avaliando o rendimento de matéria seca, a concentração de nitrogênio e o perfilhamento do capim-Vencedor (Panicum maximum Jacq. cv. Vencedor), em função de doses de nitrogênio na solução nutritiva, verificaram que o rendimento de matéria seca da parte aérea foi significativo para o primeiro e segundo corte $(P<0,01)$. Constataram em ambos os cortes, redução na produção de matéria seca da parte aérea em condições de baixas concentrações do nutriente. Verificaram que a concentração de nitrogênio nas folhas novas aumentou linearmente com 0 incremento de nitrogênio na solução nutritiva. Demonstraram que o aumento da dose de nitrogênio na solução nutritiva estimulou a quantidade de perfilhos nesse capim.

Carvalho et al. (1997) trabalharam com fontes e doses de nitrogênio aplicadas em areia quartzosa (Entissol) cultivado com capim-coastcross-1 [Cynodon dactylon (L.) Pers. Cv. coastcross-1], verificaram que a adubação nitrogenada incrementou significativamente $(P<0,05)$ a produção de matéria seca e perfilhamento, entretanto não ocorreram diferenças significativas $(P>0,05)$ entre as diferentes fontes de nitrogênio utilizadas (sulfato de amônio, nitrocálcio e uréia).

Corrêa \& Monteiro (1997) estudaram o efeito de doses de nitrogênio (42; 210 e $378 \mathrm{mg} \mathrm{L}^{-1}$ ) e de magnésio $\left(4,8\right.$ e $\left.48 \mathrm{mg} \mathrm{L}^{-1}\right)$ no perfilhamento do capim-Colonião, capim-Tanzânia-1 e capim-Vencedor durante o período de verão e encontraram efeitos significativos das doses de nitrogênio no número de perfilhos. 


\subsection{Potássio em gramíneas forrageiras}

Dentre os macronutrientes, o potássio é um dos nutrientes mais consumidos como fertilizante pela agricultura brasileira (Raij, 1991).

O potássio ocupa o segundo lugar em quantidade extraída pelas plantas (Epstein, 1975). Tem ação fundamental no metabolismo vegetal, com um efeito direto na fotossintese (Marschner,1995) e participa na translocação dos carboidratos sintetizados no processo fotossintético, além de ser ativador enzimático (Epstein, 1975).

$O$ potássio é absorvido pelas plantas como ion $\mathrm{K}^{+}$e $\mathrm{O}$ nutriente mantém-se na planta sempre nesta forma. É extremamente móvel na planta, ocorrendo transporte a longas distâncias. Habitualmente o potássio é redistribuído das folhas velhas para as folhas novas, resultando que tecidos meristemáticos apresentam altos teores de potássio (Werner, 1986).

As plantas deficientes em potássio apresentam colmos finos, raquíticos e pouco resistentes ao tombamento, as folhas são pouco desenvolvidas e em fases mais avançadas da deficiência ocorre clorose e necrose nas pontas e nas margens das mesmas, afetando portanto a produtividade da forrageira (Malavolta, 1980).

A adubação potássica em pastagens não tem sido devidamente considerada, talvez em função de que o potássio é recirculado através da urina e das fezes dos animais em pastejo. Neste sentido, Monteiro \& Werner (1994) discutiram vários aspectos relacionados com a reciclagem do potássio em áreas submetidas a pastejo, através das excreções animais, do retorno via forrageiras e da contribuição pela suplementação alimentar dos animais.

Segundo Monteiro \& Werner (1997), a forragem não consumida pelos animais apresenta-se como uma fonte importante de retorno de nutrientes para o sistema, destacando a distribuição uniforme das plantas na área da pastagem ao contrário das excreções animais cuja distribuição é 
desuniforme. De acordo Wilkinson \& Lowrey (1973), o retorno de nutrientes ao solo por lavagem das folhas (principalmente nitrogênio e potássio), por tecidos mortos da parte aérea e raizes, atingiram para o potássio até $97,3 \mathrm{~kg} \mathrm{ha}^{-1} \mathrm{ano}^{-1}$.

Vicente-Chandler et al. (1962), trabalhando com capim-colonião em solo Podzólico Vermelho-Amarelo, sob regime de cortes mecânicos, com elevada dose de nitrogênio e empregando doses de potássio de $0,220,440$, 880 e $1760 \mathrm{~kg} \mathrm{ha}^{-1}$, verificaram efeito positivo da adubação potássica até 440 $\mathrm{kg} \mathrm{ha}^{-1}$ ano $^{-1}$ na produção de matéria seca. Constataram que no local onde não se aplicou essa adubação as plantas manifestaram sintomas de deficiência de potássio

Gomide (1966), trabalhando com capim-gordura num experimento em pequenas parcelas e avaliando o efeito dos elementos nitrogênio, fósforo, potássio, enxofre e cálcio, observou que as maiores respostas na produção de matéria seca foram obtidas com o potássio.

Monteiro et al. (1980) utilizaram uma área formada com capimcolonião, a qual tinha recebido niveis de nitrogênio nos três anos anteriores. Estudaram os efeitos da reaplicação de nitrogênio e da adubação com cloreto de potássio, na dose do adubo de 0 e $167 \mathrm{~kg} \mathrm{ha}^{-1}$, sendo que no período anterior a esse experimento a forrageira recebia cloreto de potássio à base de $100 \mathrm{~kg} \mathrm{ha} \mathrm{hano}^{-1}$. Ao mesmo tempo continuaram aplicando os niveis de nitrogênio, cortando e removendo a forragem da área. Verificaram efeitos significativos do potássio na produção de matéria seca e na concentração desse nutriente na gramínea. Assim, onde se utiliza adubação com nitrogênio é necessário o suprimento de potássio para não haver limitação do efeito do nitrogênio.

Raij \& Quaggio (1984) realizaram experimento em vasos para verificar a disponibilidade de potássio em alguns solos do Estado de São Paulo, para a Brachiaria decumbens. Analisaram o potássio trocável no solo ao início e no final do experimento e determinaram o potássio na parte aérea da 
graminea. Relataram que a diminuição do teor de potássio trocável no solo foi inferior à quantidade de potássio absorvida pela planta, o que mostra ter alguma contribuição de formas não-trocáveis de potássio do solo para a nutrição da forrageira.

França \& Haag (1985), cultivando o capim-tobiatã em soluções nutritivas completa e com omissão de nutrientes, constataram que na omissão do potássio houve redução acentuada na produção de matéria seca e menor número de perfilhos que no completo.

Sanzonowicz (1986) mostrou a resposta da Brachiaria decumbens ao potássio num Latossolo Vermelho argiloso fase campo sujo, verificando aumento na produção de matéria seca até a dose de $160 \mathrm{~kg} \mathrm{ha}^{-1}$ de $\mathrm{K}_{2} \mathrm{O}$.

Mesa et al. (1989) conduziram experimento com doses de potássio de 0 até $400 \mathrm{~kg} \mathrm{ha}^{-1}$ nos capins buffel (Cenchrus ciliaris L. CV. Formidable), bermuda 68 (Cynodon dactylon L. cv. 68) rhodes (Chloris gayana Kunth. cv. callide) e guinea ( Panicum maximum cv. Likoni). Constataram aumento significativo na produção de matéria seca com potássio na dose $50 \mathrm{~kg} \mathrm{ha}^{-1}$ para bermuda 68 , rhodes e guinea.

Hernández \& Cárdenas (1990), conduzindo um experimento num solo Ferralítico Cuarcítico e avaliando os efeitos da aplicação de nitrogênio ( $N$ $=0,150,300$ e $\left.450 \mathrm{~kg} \mathrm{~N} \mathrm{ha}^{-1}\right)$, fósforo $\left(\mathrm{P}_{2} \mathrm{O}_{5}=0,50,100,150\right.$ e $\left.250 \mathrm{~kg} \mathrm{ha}^{-1}\right) \mathrm{e}$ potássio $\left(\mathrm{K}_{2} \mathrm{O}=0,100\right.$ e $200 \mathrm{~kg} \mathrm{ha}^{-1}$ ) no capim-estrela (Cynodon nlemfuensis $\mathrm{cv}$. jamaicano), constataram que nas doses respectivas de $\mathrm{N}, \mathrm{P}_{2} \mathrm{O}_{5}$ e $\mathrm{K}_{2} \mathrm{O}$ de 300,150 e 200 obtiveram os maiores rendimentos de matéria seca da graminea.

Conduzindo um experimento a campo, por dois anos, num Latossolo Vermelho-Amarelho, álico com relevo ondulado, Carvalho et al. (1991) estudaram o efeito de aplicação de nitrogênio e potássio na produtividade da Brachiaria decumbens Stapf. em regime de cortes. Empregaram três niveis de potássio $\left(\mathrm{K}_{2} \mathrm{O}=0,75\right.$, e $150 \mathrm{~kg} \mathrm{ha}{ }^{-1}$ ano $^{-1}$ no primeiro ano e 50, 100 e 
$200 \mathrm{~kg} \mathrm{ha}^{-1}$ ano $^{-1}$ no segundo ano) verificando que com baixa dose de potássio manifestaram-se sintomas de deficiência do nutriente nas folhas e que concentrações de 10 e $15 \mathrm{~g} \mathrm{~kg}^{-1}$ de potássio não resultavam em sintoma de deficiência na parte aérea da planta.

Silva et al. (1995) trabalharam com sete niveis de potássio em solução nutritiva $\left(0 ; 9,75 ; 39,78 ; 156 ; 234\right.$ e $\left.312 \mathrm{mg} \mathrm{L}^{-1}\right)$ e verificaram acentuadas respostas do capim-Tanzânia-1 ao potássio, no perfilhamento e na produção de matéria seca das folhas novas e de toda a parte aérea. Observaram também que as produções máximas ocorreriam em doses superiores às utilizados no experimento.

Monteiro et al. (1995) cultivaram a Brachiaria brizantha Stapf. cv. Marandu em solução nutritiva com omissões de macronutrientes. Constataram que a omissão de potássio na solução nutritiva não afetou a produção de matéria seca e número de perfilhos, quando comparada com o tratamento completo. Os autores observaram teores de potássio na parte aérea de 4,3 $\mathrm{g} \mathrm{kg}^{-1}$ e de $3,6 \mathrm{~g} \mathrm{~kg}^{-1}$ nas raizes, que foram significativamente mais baixos daqueles do tratamento completo, cujas partes das plantas apresentaram valores de 28,0 e $25,0 \mathrm{~g} \mathrm{~kg}^{-1}$, respectivamente.

Faquin et al. (1995b) trabalharam com braquiária (Brachiaria decumbens Stapf.) e colonião (Panicum maximum Jacq.) com niveis de potássio $(\mathrm{K})$ de $0,50,100,200$ e $400 \mathrm{mg} \mathrm{kg}^{-1}$ de solo. Constataram aumentos significativos na produção de matéria seca da parte aérea nos dois cortes e no total para ambas forrageiras. O efeito das doses de potássio não foi suficiente para promover diferenças significativas no perfilhamento do colonião, enquanto, na braquiária a significância foi verificada.

Werner \& Haag (1972) verificaram no capim-colonião um teor adequado de potássio nas lâminas de folhas novas de $18,4 \mathrm{~g} \mathrm{~kg}^{-1}$. Toledo (1984) constatou $11,5 \mathrm{~g} \mathrm{~kg}^{-1}$ de potássio como adequado na matéria seca da parte aérea no capim-colonião e Ferrari Neto (1991) encontrou na Brachiaria 
decumbens teores de potássio na parte aérea de $11 \mathrm{~g} \mathrm{~kg}^{-1}$. Gavillon \& Thereza Quadros (1969) encontraram teores de potássio superiores a $6,0 \mathrm{~g} \mathrm{~kg}^{-1}$ na matéria seca, nas pastagens nativas do Río Grande do Sul.

Gomide et al. (1969) constataram em Cynodon dactylon cv. Swannee um teor médio de potássio de $11,7 \mathrm{~g} \mathrm{~kg}^{-1}$, na ausência de adubação. Premazzi (1991) trabalhou num Latossolo Vermelho Amarelo distrófico, com doses de 50 $\mathrm{kg} \mathrm{ha-1}$ de nitrogênio, $60 \mathrm{~kg} \mathrm{ha}^{-1}$ de fósforo e $75 \mathrm{~kg} \mathrm{ha}^{-1}$ de potássio na Brachiaria brizantha e observou teor de $22 \mathrm{~g} \mathrm{~kg}^{-1}$ de potássio na matéria seca da parte aérea da forrageira. Hernández \& Cárdenas (1990) encontraram no capim-estrela (Cynodon nlemfuensis cv. jamaicano) teores de potássio, no primeiro e segundo crescimento, de $19,7 \mathrm{~g} \mathrm{~kg}^{-1}$ e $16,5 \mathrm{~g} \mathrm{~kg}^{-1}$, respectivamente quando a adubação potássica foi de $200 \mathrm{~kg} \mathrm{ha}^{-1}$.

Gallo et al. (1974) trabalharam em um estudo da composição de forrageiras coletadas no Estado de São Paulo através da análise de 249 amostras de gramíneas e leguminosas e encontraram teores de potássio de 12 a $28 \mathrm{~g} \mathrm{~kg}^{-1}$ nas gramíneas. Bufarah et al. (1982), em estudo num solo Hidromórfico em Iguape no Vale do Ribeira (SP), adubado com $500 \mathrm{~kg} \mathrm{ha}^{-1}$ de superfosfato simples e $100 \mathrm{~kg} \mathrm{ha}^{-1}$ de cloreto de potássio, obtiveram na braquiária teor de potássio de $11,7 \mathrm{~g} \mathrm{~kg}^{-1}$, na média de três cortes.

Martim (1997) avaliou efeitos da relação entre o nitrogênio e o potássio aplicados a um Latossolo Vermelho-Amarelo, para o cultivo de Coastcross 1 e Tifton 85 . Verificou que os maiores incrementos de produção de matéria seca em função da aplicação de nitrogênio ocorreram nas doses mais elevadas de potássio, enquanto as mais elevadas concentrações de nitrogênio foram obtidas nas mais baixas doses de potássio. Constatou que 0 teor de potássio na parte aérea dos capins aumentou com a adubação potássica de 13,4 para $17,4 \mathrm{~g} \mathrm{~kg}^{-1}$ e de 3,7 para $13,3 \mathrm{~g} \mathrm{~kg}^{-1}$, respectivamente no primeiro e segundo crescimento. 
Mattos (1997) conduziu dois experimentos em casa-de vegetação com solução nutritiva avaliando a diagnose nutricional de potássio nas espécies forrageiras Brachiaria decumbens e Brachiaria brizantha. Verificou que o incremento de potássio na solução nutritiva proporcionou aumentos na produção de matéria seca da parte aérea, das raízes, no perfilhamento e na concentração de potássio dos componentes da parte aérea e das raizes de ambas espécies. Constatou que o nível crítico de potássio nas lâminas de folhas novas da Brachiaria decumbens cv. Basilisk, no primeiro e segundo crescimento, foi de 23 e $20 \mathrm{~g} \mathrm{~kg}^{-1}$ de potássio na matéria seca.

\subsection{Relação nitrogênio:potássio}

As relações dos nutrientes podem ser responsáveis por significativas mudanças na disponibilidade de nutrientes, podendo influenciar na função dos íons e no desenvolvimento fisiológico das plantas. A compreensão destas interações poderia ajudar a melhorar as recomendações de adubação e também aumentar a eficiência do fertilizante utilizado (Usherwood, 1982).

A adubação nitrogenada tem, por vezes, apresentado respostas produtivas abaixo das esperadas em virtude de inadequados níveis de potássio, o que sugere uma relação entre absorção e aproveitamento destes dois macronutrientes (Monteiro et al., 1980).

Hernández \& Cárdenas (1990) trabalharam com capim-estrela jamaicano com quatro doses de nitrogênio $\left(N=0,150,300\right.$ e $\left.450 \mathrm{~kg} \mathrm{ha}^{-1}\right)$, cinco de fósforo $\left(\mathrm{P}_{2} \mathrm{O}_{5}=0,50,100,150\right.$ e $\left.200 \mathrm{~kg} \mathrm{ha}^{-1}\right)$ e três níveis de potássio $\left(\mathrm{K}_{2} \mathrm{O}=0,100\right.$ e $\left.200 \mathrm{~kg} \mathrm{ha}^{-1}\right)$. Aplicaram o fósforo na semeadura, o potássio duas vezes ao ano e o nitrogênio depois de cada corte, em intervalos de 49 e 56 dias na época das chuvas e na época da seca, respectivamente. Verificaram aumentos significativos na produção de matéria seca até $28,2 \mathrm{Mg} \mathrm{ha}^{-1}$ no

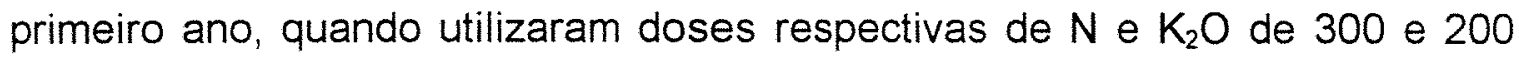


$\mathrm{kg} \mathrm{ha}^{-1}$. No segundo ano constataram aumentos na produção de matéria seca até doses de $\mathrm{N}, \mathrm{P}_{2} \mathrm{O}_{5}$ e $\mathrm{K}_{2} \mathrm{O}$ de 300,150 e $200 \mathrm{~kg} \mathrm{ha}^{-1}$, produzindo $96,4 \%$ do rendimento obtido no primeiro ano.

Herling et al. (1991) cultivaram o capim-setária (Setaria anceps Stapf. Ex. Massey cv. kazungula) num Latossolo Vermelho-Escuro Orto, sob três doses de nitrogênio $\left(0,80\right.$ e $\left.160 \mathrm{~kg} \mathrm{ha}^{-1}\right)$, duas de potássio ( 0 e $\left.80 \mathrm{~kg} \mathrm{ha}^{-1}\right)$ em quatro estádios de crescimento (30,40,50 e 60 dias). Verificaram que a produção de matéria seca e o número de perfilhos foram maiores em idades mais avançadas e com aumento da adubação nitrogenada. Constataram que ao dobrar a dose de nitrogênio o nível de resposta foi inferior ao esperado e acrescentaram que a adubação potássica teve influência significativa somente na produção de matéria seca, quando incrementou apenas $16,72 \%$.

Carvalho et al. (1991) conduziram um experimento de campo, por dois anos, em um Latossolo Vermelho-Amarelo álico, onde estudaram o efeito de aplicação de nitrogênio $\left(0,100,200\right.$ e $\left.400 \mathrm{~kg} \mathrm{ha}^{-1} \mathrm{ano}^{-1}\right)$ e potássio $(0,75 \mathrm{e}$ $150 \mathrm{~kg} \mathrm{ha}^{-1} \mathrm{ano}^{-1}$ ) na produtividade da Brachiaria decumbens Stapf., em regime de cortes. Observaram que houve um efeito positivo da adubação nitrogenada na produção de matéria seca da braquiária e que esse efeito dependeu da aplicação de potássio. Constataram que com baixo nivel de aplicação de potássio a resposta a nitrogênio foi limitada, mas com o aumento do nivel de potássio ocorreu acentuada resposta a nitrogênio. Verificaram que as concentrações de nitrogênio na forragem aumentaram linearmente com os niveis de nitrogênio, atingindo valores entre 17 e $21 \mathrm{~g} \mathrm{~kg}^{-1}$, enquanto que diminuíram com o aumento no nível de potássio, em decorrência da maior produção de matéria seca. Acrescentaram que com baixa dose de potássio (75 kg ha ${ }^{-1}$ ano $^{-1}$ ) desenvolveram-se sintomas de deficiência do nutriente nas folhas, porém na ausência desses sintomas as concentrações de potássio na parte aérea foram de 10 e $15 \mathrm{~g} \mathrm{~kg}^{-1}$. 
Martim et al. (1997) trabalharam com os capins-bermuda Coastcross 1 e Tifton 85 num Latossolo Vermelho-Amarelo e procuraram avaliar alguns efeitos da interação entre o nitrogênio e o potássio. Tanto o nitrogênio como o potássio foram aplicados no início do experimento e após o primeiro e o segundo corte das forrageiras. As doses utilizadas de $\mathrm{N}$ e $\mathrm{K}$ foram 8, 40, e 72 $\mathrm{mg} \mathrm{kg}^{-1}$ de terra e 6,30 e $54 \mathrm{mg} \mathrm{kg}^{-1}$ de terra, respectivamente. Constataram que a interação $\mathrm{NxK}$ foi significativa e bem evidente no terceiro crescimento das plantas, e que os maiores incrementos de produção ocorreram nas doses mais elevadas de potássio, enquanto as maiores concentrações de nitrogênio foram verificadas nas mais baixas doses de potássio. Observaram que o teor de potássio nas raízes elevou-se linearmente com a aplicação de potássio ao solo, mas esse teor foi mais elevado quanto mais baixa foi a adubação nitrogenada.

O estudo dos nutrientes isoladamente e a relação entre eles pode esclarecer dúvidas relativas à nutrição e adubação da planta considerada, assim como também sobre o potencial produtivo da espécie, contribuindo a informação obtida para o melhor aproveitamento da forrageira. 


\section{MATERIAL E MÉTODOS}

\subsection{Local, período e espécie forrageira}

O experimento foi realizado em casa-de-vegetação do Setor de Nutrição Mineral de Plantas, Departamento de Quimica, Escola Superior de Agricultura "Luiz de Queiroz" - USP, em Piracicaba, SP. Cultivou-se a Brachiaria decumbens Staf. cv. Basilisk durante os meses de outubro de 1997 a fevereiro de 1998 , com temperatura ambiente variando de 26 a $42^{\circ} \mathrm{C}$.

\subsection{Tratamentos, soluções nutritivas e delineamento experimental}

Foi empregado um esquema fatorial $5 \times 3$, com cinco doses de nitrogênio e três doses de potássio, perfazendo um total de 15 combinações, as quais foram distribuídas segundo o delineamento experimental de blocos completos ao acaso, com quatro repetições.

As doses de nitrogênio corresponderam a: 42; 140; 238; 336 e 434 $\mathrm{mg} \mathrm{L}^{-1} \mathrm{e}$ as de potássio a: $78 ; 234$ e $390 \mathrm{mg} \mathrm{L}^{-1}$. As soluções foram preparadas a partir daquela proposta por Sarruge (1975), devidamente modificada para as doses de nitrogênio e potássio propostas e atendendo 0 suprimento dos demais macro e micronutrientes, conforme composição apresentada na Tabela 1. 
Tabela 1. Volumes de soluções estoques utilizados na preparação das soluções nutritivas, em função das combinações das doses de nitrogênio ${ }^{(1)}$ e potássio.

\begin{tabular}{|c|c|c|c|c|c|c|c|c|c|c|c|c|c|c|c|}
\hline \multicolumn{16}{|c|}{ Doses dos nutrientes } \\
\hline $\mathrm{K}\left(\mathrm{mg} \mathrm{L^{-9 } )}\right.$ & \multicolumn{5}{|c|}{78} & \multicolumn{5}{|c|}{234} & \multicolumn{5}{|c|}{390} \\
\hline$N\left(m g L^{-1}\right)$ & 42 & 140 & 238 & 336 & 434 & 42 & 140 & 238 & 336 & 434 & 42 & 140 & 238 & 336 & 434 \\
\hline Solução estoque & \multicolumn{15}{|c|}{ Volume $\left(\mathrm{ml} \mathrm{L}^{-1}\right)$} \\
\hline $\mathrm{KH}_{2} \mathrm{PO}_{4} \mathrm{M}$ & 1 & 1 & 1 & 1 & 1 & 1 & 1 & 1 & 1 & 1 & 1 & 1 & 1 & 1 & 1 \\
\hline $\mathrm{KNO}_{3} \mathrm{M}$ & $\overline{1}$ & 28 & 1 & 1 & 1 & 1 & 20 & 5 & 5 & 5 & 1 & 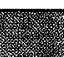 & 9 & 9 & 9 \\
\hline $\mathrm{Ca}\left(\mathrm{NO}_{3}\right)_{2} \mathrm{M}$ & 1 & 5 & 5 & 5 & 5 & 1 & 5 & 3,5 & 5 & 5 & 1 & 5 & 4 & 5 & 5 \\
\hline $\mathrm{MgSO}_{4} \mathrm{M}$ & 2 & 2 & 2 & 2 & 2 & 2 & 2 & 2 & 2 & 2 & 2 & 2 & 2 & 2 & 2 \\
\hline $\mathrm{KCl} \mathrm{M}$ & & 1 & & & & 4 & 5 & & & & 8 & 9 & & & \\
\hline $\mathrm{CaCl}_{2} \mathrm{M}$ & 4 & & & & & 4 & & 1,5 & & & 4 & & 1 & & \\
\hline $\mathrm{NH}_{4} \mathrm{NO}_{3} \mathrm{M}$ & & & 3 & 6 & 9 & & & 2,5 & 4,5 & 8 & & & & 2,5 & 6 \\
\hline $\mathrm{NaNO}_{3} \mathrm{M}$ & & & 站 & 1 & 2 & & & & & & & & & & 管 \\
\hline Micronutrientes $^{(2)}$ & 1 & 1 & 1 & 1 & 1 & 1 & 1 & 1 & 1 & 1 & 1 & 1 & 1 & 1 & 1 \\
\hline Fe EDTA & 1 & 1 & 1 & 1 & 1 & 1 & 1 & 1 & 1 & 1 & 1 & 1 & 1 & 1 & 1 \\
\hline
\end{tabular}

'Concentração dos demais macronutrientes na solução nutritiva de Sarruge: $P=31 \mathrm{mg} \mathrm{L}^{-1}$;

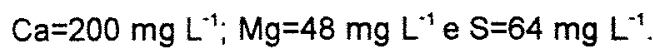

${ }^{2}$ Composição da solução de micronutrientes: $\mathrm{H}_{3} \mathrm{BO}_{3}=2,86 \mathrm{~g} \mathrm{~L}^{-1} ; \mathrm{MnCl}_{2} 4 \mathrm{H}_{2} \mathrm{O}=1,81 \mathrm{~g} \mathrm{~L}^{-1}$; $\mathrm{ZnCl}_{2}=0,10 \mathrm{~g} \mathrm{~L}^{-1} ; \mathrm{CuCl}_{2}=0,04 \mathrm{~g} \mathrm{~L}^{-1}, \mathrm{H}_{2} \mathrm{MOO}_{4} \cdot \mathrm{H}_{2} \mathrm{O}=0,02 \mathrm{~g} \mathrm{~L}^{-1}$ e FeSO $4.7 \mathrm{H}_{2} \mathrm{O}=24 \mathrm{~g} \mathrm{~L}-1$.

\subsection{Instalação e condução do experimento}

Ao final de outubro foram colocadas as sementes para germinar em bandejas de alumínio, contendo areia lavada. Quinze mudas com cerca de três centimetros de altura foram transplantadas no dia 14 de novembro para cada vaso de plástico, com volume de 3,6 L preenchido com sílica. $\mathrm{Na}$ primeira semana após o transplante as plantas receberam solução nutritiva diluída em $30 \%$ da concentração total correspondente às mais baixas doses de nitrogênio e potássio empregadas no experimento. Nesta fase procederam-se a desbastes periódicos até que cada vaso ficasse com cinco 
plantas. Após esse periodo foram adicionadas as soluções nutritivas definitivas, que foram circuladas através da sílica três vezes por dia e trocadas a cada catorze dias a partir da primeira adição de solução correspondente a cada combinação nitrogênio-potássio. Durante o período do experimento, a cada sete dias, os vasos eram remanejados dentro de cada bloco.

\subsection{Determinação do número de perfilhos e coleta do material vegetal}

Aos 43 dias após o transplante, em 27 de dezembro de 1997, foi realizado o primeiro corte das plantas a uma altura de dois centímetros do colo das plantas. O material colhido foi separado em folhas não-expandidas; lâminas de folhas novas (lâminas das duas folhas superiores totalmente expandidas); lâminas de folhas velhas (lâminas das demais folhas totalmente expandidas); colmos+bainhas e inflorescências. As folhas foram consideradas totalmente expandidas quando apresentavam a lígula visivel.

No segundo corte, 31 dias após o primeiro, em 27 de janeiro de 1998, ao nivel do substrato, as plantas foram cortadas e separadas segundo o mesmo critério do primeiro corte, sendo que as raizes também foram separadas e lavadas.

Ao final do primeiro e do segundo crescimento, antes de efetuar 0 corte das plantas realizou-se a contagem do número total de perfilhos nas cinco plantas de cada vaso.

Todo o material vegetal colhido foi secado em estufa de circulação forçada de ar, à temperatura de $65^{\circ} \mathrm{C}$, até peso constante, sendo então pesado, moído em moinho tipo Wiley e acondicionado em saco de plástico. 


\subsection{Produção de matéria seca}

Para a obtenção dos valores de produção de matéria seca da parte aérea foram somados os valores das pesagens das partes separadas em cada corte, ou seja folhas não-expandidas, lâminas de folhas novas, lâminas de folhas velhas, colmos + bainhas e inflorescência após a secagem em estufa. Os valores da pesagem das raízes foram anotados diretamente.

\subsection{Análises químicas}

Para a determinação das concentrações dos macronutrientes no tecido vegetal foram empregadas as lâminas de folhas novas, conforme recomendado para essa forrageira por Mattos (1997) e Santos (1997). As análises foram executadas conforme metodologia descrita por Sarruge \& Haag (1974). A digestão utilizada para a obtenção do extrato na determinação do nitrogênio total foi a sulfúrica e a destilação foi conduzida em aparelho semi-micro Kjeldahl, titulando-se posteriormente com ácido sulfúrico. A digestão utilizada para a obtenção dos teores dos demais macronutrientes foi a nítrico-perclórica. Para a determinação do potássio o método analítico foi o da fotometria de chama, para o cálcio e o magnésio empregou-se a espectrofotometria de absorção atômica e para o fósforo utilizou-se o método colorimétrico. $O$ enxofre foi determinado por via indireta, através da precipitação do sulfato pelo bário, efetuando-se a leitura do bário na solução pelo espectrofotometro de absorção atômica (Bataglia, 1976).

\subsection{Análises estatísticas}

Foram realizadas utilizando-se o programa estatístico SAS-System for Windows release 6.11 (SAS Inst. Inc., 1996). Os resultados foram 
submetidos à análise de variância e no caso do teste $F$ significativo a no mínimo de $95 \%$ de probabilidade $(P<0,05)$, procedeu-se ao desdobramento da interação $\mathrm{N} \times \mathrm{K}$ ou à análise de regressão.

No desdobramento das interações que envolviam doses de nitrogênio e doses de potássio identificaram-se em quais doses de nitrogênio ocorreram os efeitos devido às doses de potássio e em quais doses de potássio eram significativos os efeitos devido às doses de nitrogênio. A partir daí efetuou-se o estudo das regressões e os efeitos que mostraram significância tiveram suas equações calculadas.

A análise de regressão foi realizada para quantidade de matéria seca e teores dos macronutrientes, bem como o teste de comparação de médias (Tukey, ao nivel de $95 \%$ de probabilidade) foi conduzido para 0 número de perfilhos. 


\section{RESULTADOS E DISCUSSÃO}

\subsection{Produção de matéria seca}

\subsubsection{Folhas não-expandidas}

$\mathrm{Na}$ análise de variância para produção de matéria seca das folhas não-expandidas no primeiro e no segundo crescimento das plantas observouse que não foi significativa a interação entre doses de nitrogênio e doses de potássio.

A produção das folhas não-expandidas em função das doses de nitrogênio no primeiro crescimento foi representada por um modelo linear, enquanto no segundo crescimento foi ajustada a um modelo quadrático (Figura 1).

A máxima produção de matéria seca nas folhas não-expandidas, no segundo corte, ocorreu com nitrogênio na solução em $421 \mathrm{mg} \mathrm{L}^{-1}$. Este valor está próximo ao relatado por Santos (1997) que observou as máximas produções de matéria seca da parte aérea da Brachiaria decumbens Stapf. nas doses de nitrogênio de 435 e $433 \mathrm{mg} \mathrm{L}^{-1}$, no primeiro e no segundo corte, respectivamente. Neste caso, fica evidenciado que a maior produção de folhas não-expandidas ocorreu com dose mais elevada de nitrogênio na solução que aquela recomendada na solução de Sarruge (1975). 


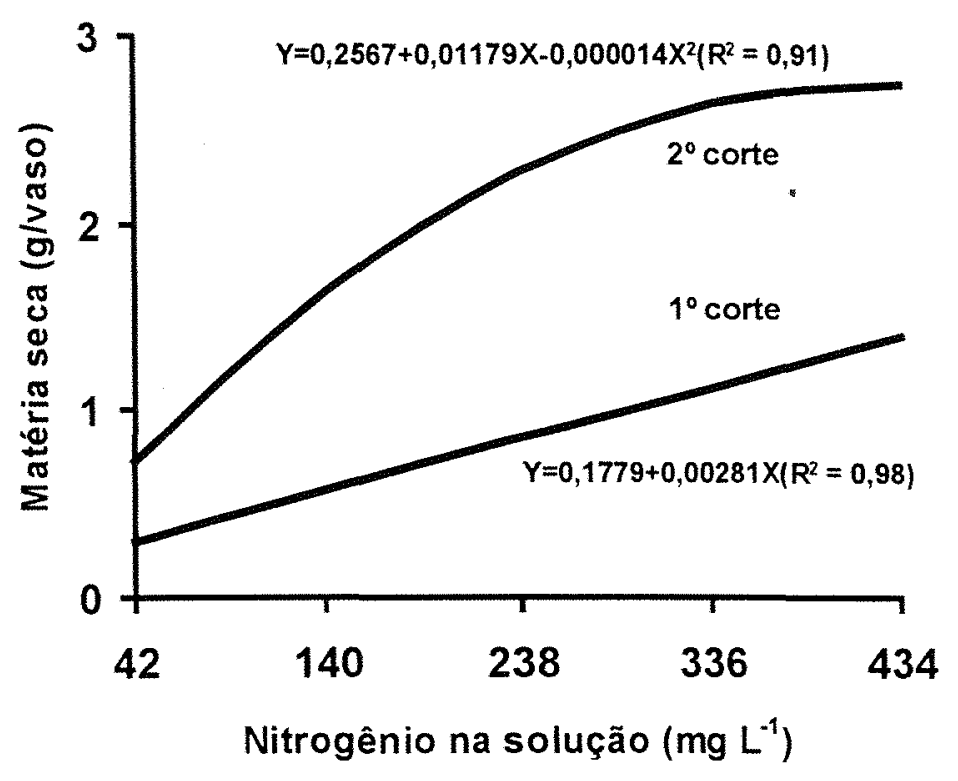

Figura 1 - Produção de matéria seca das folhas não-expandidas da braquiária decumbens, no primeiro e segundo corte, em função das doses de nitrogênio na solução nutritiva.

Observou-se na produção de folhas não-expandidas significância $(P<0,01)$ para as doses de potássio, em ambos os crescimentos. Em função das doses de potássio, a produção de matéria seca das folhas não-expandidas ajustou-se a uma equação de segundo grau no primeiro crescimento e de primeiro grau no segundo crescimento (Figura 2).

Verificou-se a máxima produção de matéria seca das folhas nãoexpandidas, no primeiro crescimento das plantas, em $228 \mathrm{mg} \mathrm{L}^{-1}$ de potássio na solução. Mattos (1997) obteve a máxima produção de matéria seca da parte aérea do capim-braquiária, em dose de potássio de $346 \mathrm{mg} \mathrm{L}^{-1}$ e $315 \mathrm{mg} \mathrm{L}^{-1}$, no primeiro e no segundo crescimento, respectivamente. 


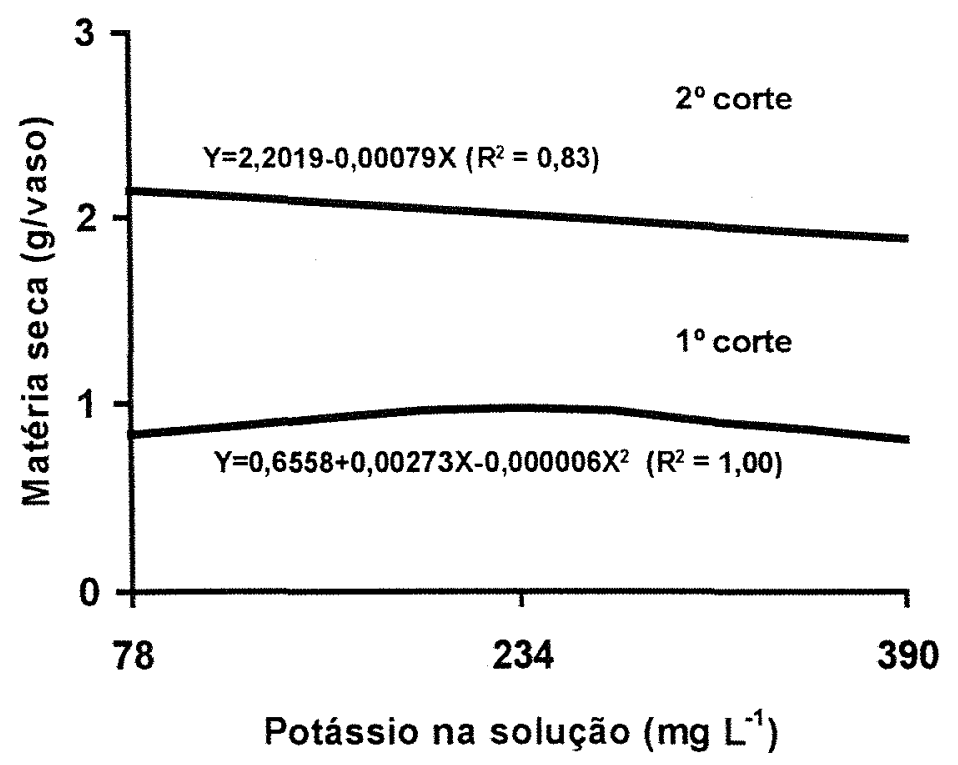

Figura 2 - Produção de matéria seca das folhas não-expandidas da braquiária decumbens, no primeiro e no segundo corte, em função das doses de potássio na solução nutritiva.

\subsubsection{Lâminas de folhas novas}

A análise de variância da produção de matéria seca das lâminas de folhas novas mostrou significância no primeiro $(P<0,01)$ e no segundo corte $(P<0,05)$ para a interação entre nitrogênio e potássio.

No estudo das doses de nitrogênio dentro de cada dose de potássio verificou-se efeito significativo $(P<0,01)$ para o nitrogênio nas três doses de potássio, tanto no primeiro como no segundo corte. Em qualquer dos casos estudados a resposta ao nitrogênio se ajustou a modelo linear (Figura 3). 

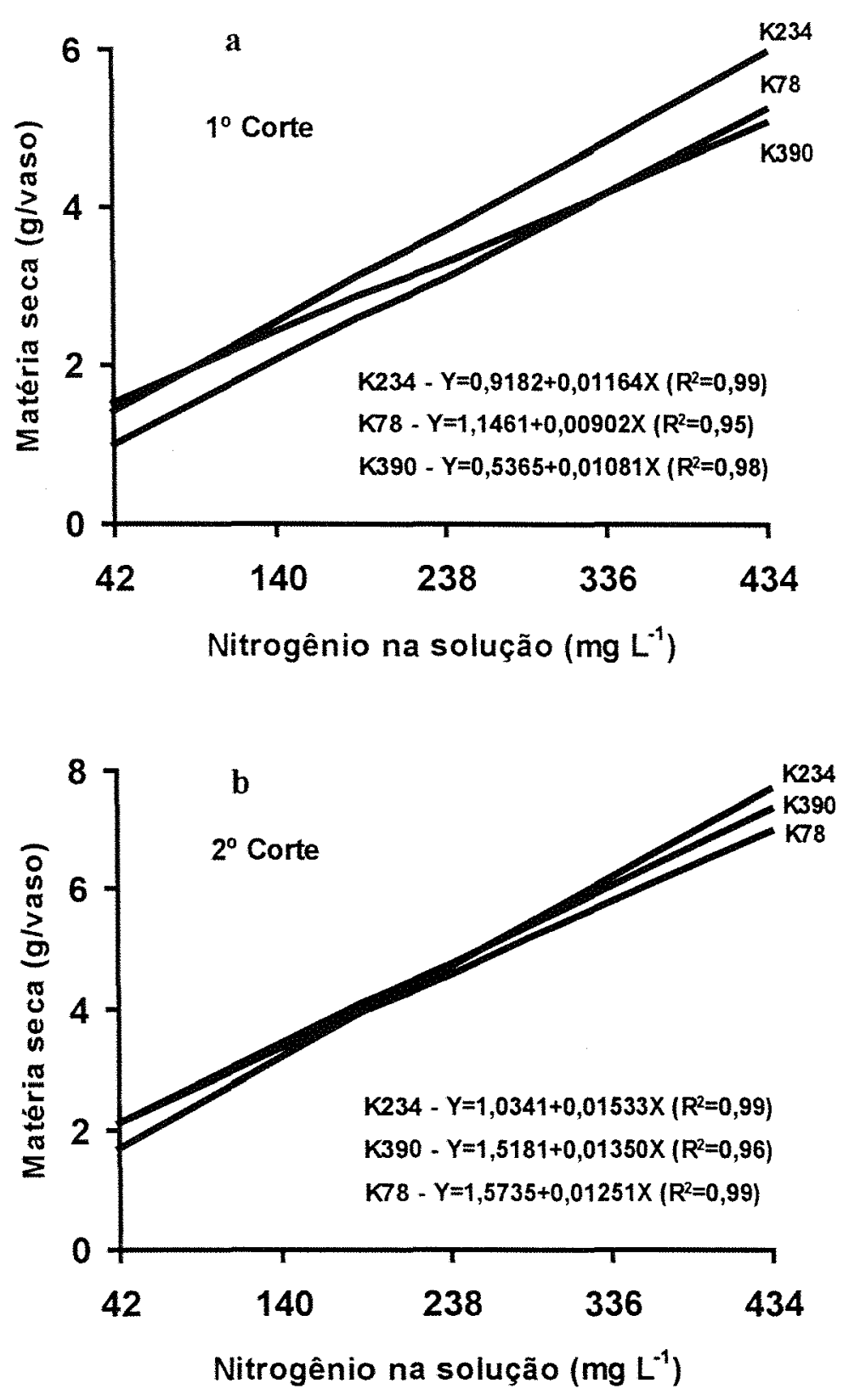

Figura 3 - Produção de matéria seca das lâminas de folhas novas da braquiária decumbens, no primeiro (a) e no segundo (b) corte, em função das doses de nitrogênio dentro de cada dose de potássio na solução nutritiva. 
Através da Figura 3 pode-se observar que o maior valor da produção de matéria seca nas lâminas de folhas novas, tanto no primeiro como no segundo corte, foi verificado com a maior dose de nitrogênio $\left(434 \mathrm{mg} \mathrm{L}^{-1}\right)$ em presença da dose de potássio de $234 \mathrm{mg} \mathrm{L}^{-1}$. Neste caso a relação entre as concentrações de nitrogênio e de potássio na solução nutritiva foi de $1,85: 1$.

No estudo das doses de potássio dentro de cada dose de nitrogênio constatou-se, no primeiro corte, significância para potássio dentro da dose de nitrogênio de $238 \mathrm{mg} \mathrm{L}^{-1}(P<0,01)$, quando uma equação do segundo grau representou este efeito e dentro da dose de nitrogênio de $336 \mathrm{mg} \mathrm{L}^{-1}(P<0,05)$, situação em que obedeceu a um modelo linear (Figura 4). O ponto de máxima produção de matéria seca nas lâminas de folhas novas ocorreu com $229 \mathrm{mg} \mathrm{L}^{-1}$ de potássio na solução, quando o nitrogênio foi suprido em $238 \mathrm{mg} \mathrm{L}^{-1}$. Nas doses de nitrogênio de 42, 140 e $434 \mathrm{mg} \mathrm{L}^{-1}$ não se verificou efeito significativo $(P>0,05)$ para a produção de lâminas novas no primeiro crescimento, em função das doses de potássio na solução. No estudo das doses de potássio dentro de cada dose de nitrogênio, no segundo corte, não se verificou significância $(P>0,05)$ para potássio dentro das doses de nitrogênio.

Silva et al. (1995), trabalhando com capim-Tanzânia-1 (Panicum maximum) cultivado em sete niveis de potássio $(0 ; 9,75 ; 39 ; 78 ; 156 ; 234$ e 312

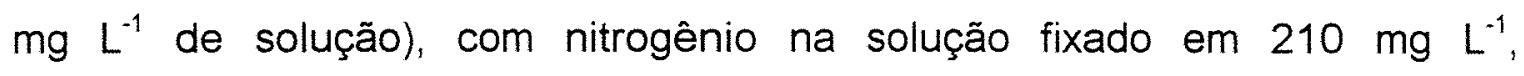
demonstraram que o modelo quadrático teve melhor ajuste para a produção de lâminas de folhas novas. Isto também concorda com Mattos et al. (1997), os quais verificaram que a máxima produção de matéria seca em capim-Tanzânia-1 ocorreu nas doses de potássio de 348 e $325 \mathrm{mg} \mathrm{L}^{-1}$ no primeiro e segundo corte, respectivamente. Esses valores observados foram mais elevados que os obtidos neste experimento, em que a dosagem de potássio de $229 \mathrm{mg} \mathrm{L}^{-1}$ com nitrogênio em $238 \mathrm{mg} \mathrm{L}^{-1}$ de solução resultou na máxima produção de matéria seca das lâminas de folhas novas. 


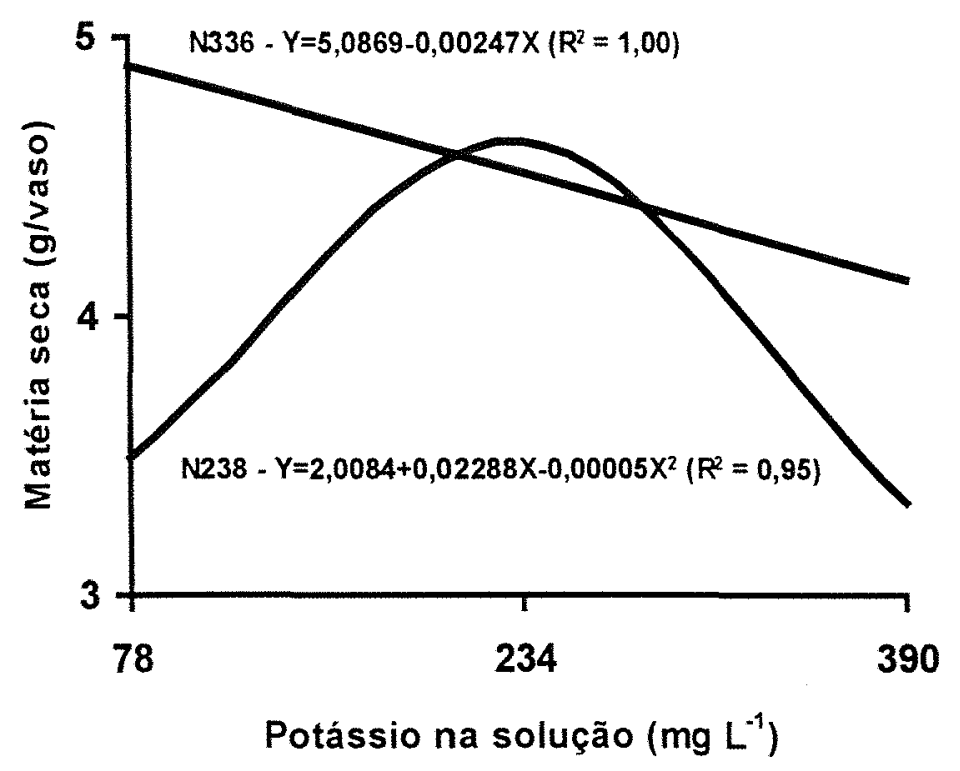

Figura 4 - Produção de matéria seca das lâminas de folhas novas da braquiária decumbens, no primeiro corte, em função das doses de potássio dentro de duas doses de nitrogênio na solução nutritiva.

\subsubsection{Lâminas de folhas velhas}

Na produção de lâminas de folhas velhas da forrageira no primeiro e no segundo corte observou-se que não foi significativa $(P>0,05)$ a interação entre doses de nitrogênio e doses de potássio. As doses de nitrogênio influenciaram significativamente $(P<0,01)$ a produção de lâminas de folhas velhas em ambos os períodos de crescimento da braquiária, enquanto as doses de potássio somente tiveram significância $(P<0,05)$ em tal produção no primeiro corte.

O efeito das doses de nitrogênio na produção de lâminas de folhas velhas, em ambos os crescimentos da planta, ajustou-se a modelo linear 
(Figura 5). A máxima produção de matéria seca de lâminas de folhas velhas ocorreria em dose superior à mais alta empregada neste estudo.

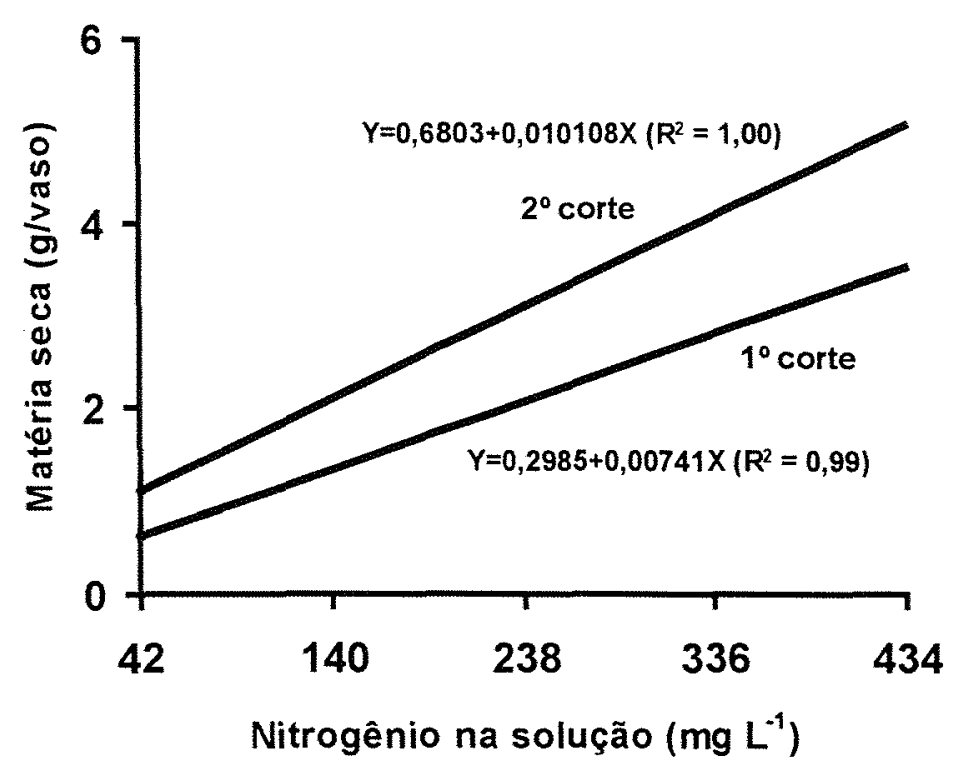

Figura 5 - Produção de matéria seca das lâminas de folhas velhas da braquiária decumbens, no primeiro e segundo corte, em função das doses de nitrogênio na solução.

A produção de lâminas velhas no primeiro corte, em função das doses de potássio ajustou-se a uma equação de segundo grau (Figura 6). O ponto de máxima produção de matéria seca das lâminas de folhas velhas ocorreu com potássio na solução em $216 \mathrm{mg} \mathrm{L}^{-1}$.

Silva et al. (1995), trabalhando com capim-Tanzânia 1 (Panicum maximum) cultivado em sete doses de potássio $(0 ; 9,75 ; 39 ; 78 ; 156 ; 234$ e 312 $\mathrm{mg} \mathrm{L}^{-1}$ ) constataram que o modelo linear teve melhor ajuste para a produção de matéria seca nas lâminas de folhas velhas. 


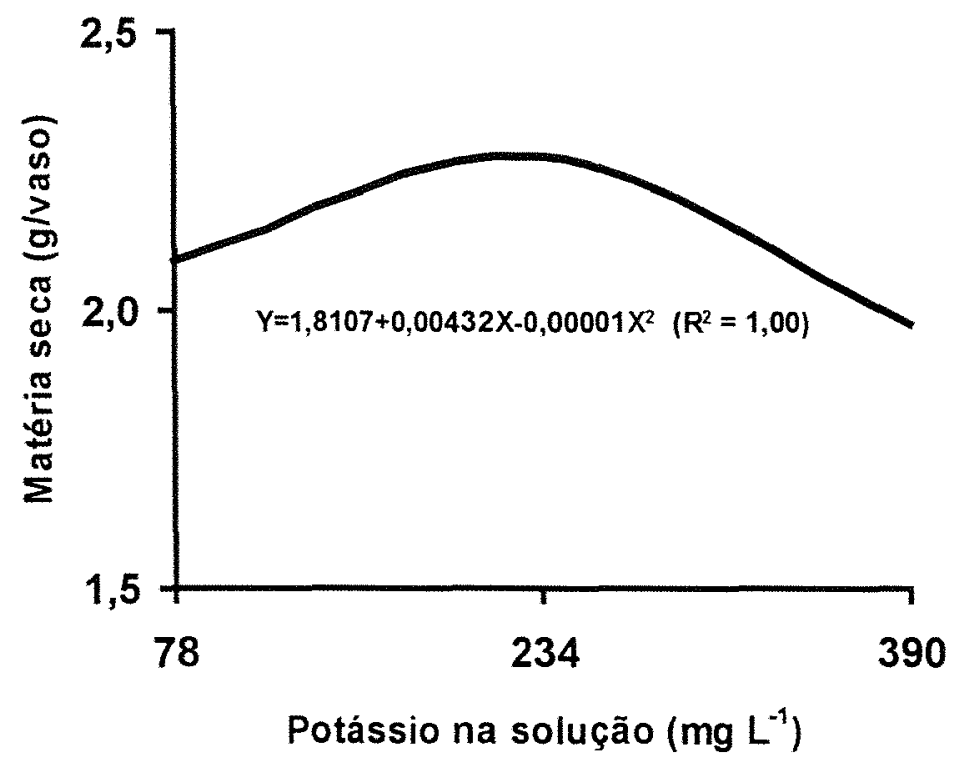

Figura 6 - Produção de matéria seca das lâminas de folhas velhas da braquiária decumbens, no primeiro corte, em função das doses de potássio na solução nutritiva.

\subsubsection{Colmos mais bainhas}

A interação entre doses de nitrogênio e doses de potássio, em termos de produção de matéria seca dos colmos mais bainhas foi significativa $(P<0,05)$ no primeiro crescimento, mas não foi significativa $(P>0,05)$ no segundo crescimento das plantas.

No desdobramento da interação, para nitrogênio dentro de doses potássio verificou-se efeito significativo $(P<0,01)$ para o nitrogênio nas três doses de potássio, no primeiro corte, obedecendo equações de primeiro grau em todos os casos (Figura 7). 


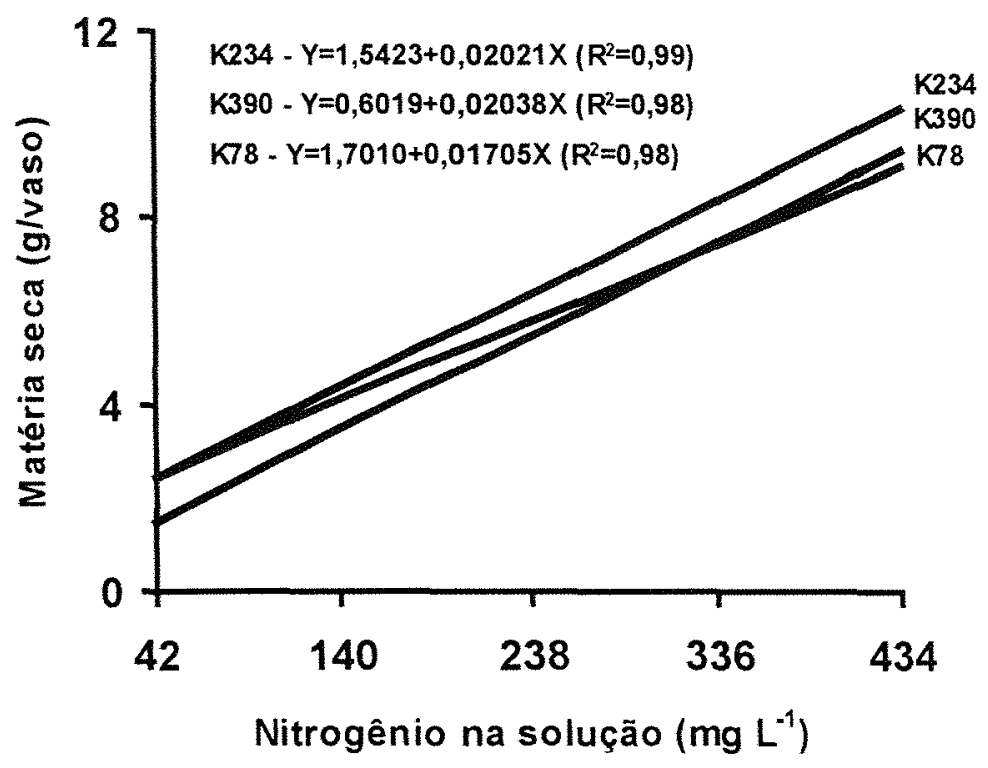

Figura 7 - Produção de matéria seca dos colmos mais bainhas da braquiária decumbens, no primeiro corte, em função das doses de nitrogênio dentro de doses potássio na solução nutritiva.

Pode-se observar, pela Figura 7, que a maior produção de matéria seca nos colmos mais bainhas, em termos absolutos, no primeiro corte, foi verificada quando se utilizou a maior dose de nitrogênio (434 $\mathrm{mg} \mathrm{L}^{-1}$ ) em presença de potássio em $234 \mathrm{mg} \mathrm{L}^{-1}$. A exemplo do que ocorreu com a produção de lâminas de folhas novas, isto foi constatado com a relação entre as concentrações de nitrogênio e potássio na solução nutritiva igual a 1,85:1.

No estudo das doses de potássio dentro de cada dose de nitrogênio, no primeiro corte, observou-se significância $(P<0,01)$ para o potássio dentro da dose $42 \mathrm{mg} \mathrm{N} \mathrm{L}^{-1}$ quando uma equação de primeiro grau representou este efeito e dentro da dose $238 \mathrm{mg} \mathrm{N} \mathrm{L}^{-1}$ quando obedeceu a um modelo quadrático (Figura 8). Neste caso a máxima produção de matéria seca dos colmos mais bainhas ocorreu em $238 \mathrm{mg} \mathrm{L}^{-1}$ de potássio na solução. Nas doses de nitrogênio de 140,336 e $434 \mathrm{mg} \mathrm{L}^{-1}$ não se verificou efeito significativo 
$(P>0,05)$ para a produção dos colmos mais bainhas, no primeiro corte, em função das doses de potássio na solução.

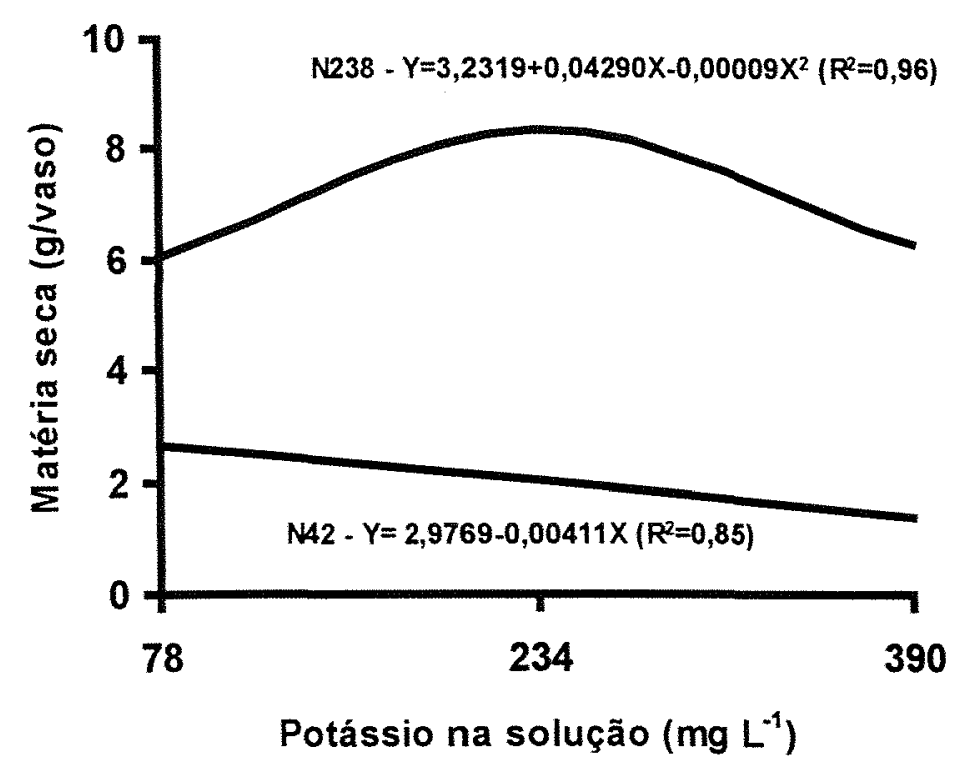

Figura 8 - Produção de matéria seca dos colmos mais bainhas no primeiro corte da braquiária decumbens, em função das doses de potássio dentro de duas doses nitrogênio na solução nutritiva.

No material de colmos mais bainhas colhidos no segundo corte, observou-se significância $(P<0,01)$ para as doses de nitrogênio, sendo representado esse efeito por um modelo linear. Entretanto não se verificou significância $(P>0,05)$ para as doses de potássio, no que se refere à produção de colmos mais bainhas da braquiária nesse segundo corte. Por outro lado, Silva et al. (1995), trabalhando com o capim-Tanzânia-1, submetido a sete niveis de potássio em solução nutritiva, verificaram que o efeito linear melhor evidenciou o comportamento desta gramínea para o componente colmos mais bainhas, em um único crescimento das plantas. 


\subsubsection{Produção de matéria seca da parte aérea}

A análise de variância da produção de matéria seca da parte aérea revelou ter sido significativa no primeiro corte $(P<0,01)$ mas não significativa no segundo corte $(P>0,05)$ a interação entre doses de nitrogênio e doses de potássio. No segundo corte, somente se constatou significância $(P<0,01)$ para as doses de nitrogênio.

No estudo das doses de nitrogênio dentro de cada dose de potássio, na produção de matéria seca no primeiro corte verificou-se efeito significativo $(P<0,01)$ para o nitrogênio em cada dose de potássio e em qualquer dos casos analisados a resposta do nitrogênio se ajustou a modelo linear (Figura 9).

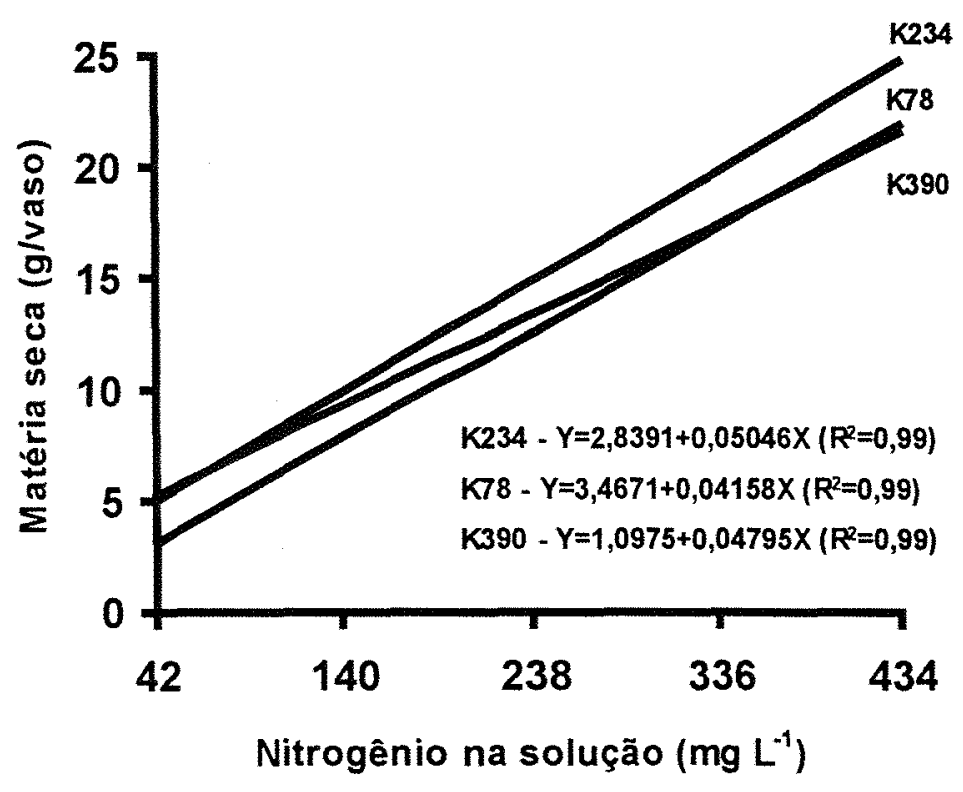

Figura 9 - Produção de matéria seca da parte aérea da braquiária decumbens, no primeiro corte, em função das doses de nitrogênio dentro de cada dose de potássio na solução nutritiva. 
Quando considerada em termos absolutos, a maior produção de matéria seca da parte aérea, no primeiro corte, foi alcançada mediante o suprimento de nitrogênio na solução em $434 \mathrm{mg} \mathrm{L}^{-1}$ e em presença da maior dose de potássio de $390 \mathrm{mg} \mathrm{L}^{-1}$. De forma similar ao verificado com a produção de lâminas de folhas novas e de colmos mais bainhas, novamente isto ocorreu quando a relação entre as concentrações de nitrogênio e potássio na solução nutritiva era de $1,85: 1$.

Os resultados apresentados mais uma vez comprovam que o nitrogênio é importante para a produção de matéria seca da forrageira, mas deve ser acompanhado de uma adubação potássica equilibrada para proporcionar melhores rendimentos, conforme apontado por Robinson (1985).

O acréscimo significativo na produção de matéria seca da parte aérea de forrageiras é amplamente documentada na literatura ( Chandler, 1973; Novoa, 1981; Corsi, 1984; Gomide, 1989; Corrêa, 1996), cujas respostas diferem em função da espécie forrageira, do clima, das doses do nutriente e do manejo (Werner, 1986; Pietrosemoli et al.,1996).

Também foram observadas altas respostas da braquiária ao nitrogênio no trabalho de Harding \& Grof (1978), quando estudaram doses de nitrogênio em Brachiaria decumbens e constataram como ótima a dose de nitrogênio de $365 \mathrm{~kg} \mathrm{ha}^{-1} \mathrm{ano}^{-1}$, em termos de produção de matéria seca e aproveitamento de nitrogênio. Vicente-Chandler et al. (1962) trabalhando com Brachiaria ruziziensis obtiveram respostas ao nitrogênio até $400 \mathrm{~kg} \mathrm{ha}^{-1} \mathrm{ano}^{-1}$. Carvalho et al. (1991) verificaram respostas marcantes na produção de matéria seca da Brachiaria decumbens quando submetida até a dose de nitrogênio de $400 \mathrm{~kg} \mathrm{ha}^{-1}$ ano $^{-1}$. Hoffmann (1992) verificou a máxima produção na Brachiaria decumbens na dose de nitrogênio de $437 \mathrm{mg} \mathrm{kg}^{-1}$ de solo. Pietrosemoli et al. (1996) observaram as maiores produções de matéria seca da Brachiaria brizantha quando o nitrogênio foi empregado na quantidade de 400 $\mathrm{kg} \mathrm{ha}^{-1} \mathrm{ano}^{-1}$. 
No desdobramento da interação para o estudo de potássio dentro de doses nitrogênio em termos da produção da parte aérea verificou-se efeito significativo $(P<0,01)$ do potássio nas doses de nitrogênio 42 e $238 \mathrm{mg} \mathrm{L}^{-1}$, sendo representado este efeito através de equações do segundo grau. Nestes casos a máxima produção de matéria seca na parte aérea ocorreu em $155 \mathrm{mg} \mathrm{L}^{-1}$ de potássio na solução quando a dose de nitrogênio foi de $42 \mathrm{mg} \mathrm{L}^{-1}$ e $222 \mathrm{mg} \mathrm{L}^{-1}$ de potássio quando o nitrogênio foi suprido em $238 \mathrm{mg} \mathrm{L}^{-1}$ (Figura 10). Na dose de $336 \mathrm{mg} \mathrm{L}^{-1}$ de nitrogênio constatou-se significância $(P<0,05)$ para as doses de potássio, situação em que uma equação de primeiro grau representou esse efeito (Figura 11). Dentro das doses 140 e $434 \mathrm{mg} \mathrm{L}^{-1}$ não foi verificado efeito significativo $(P>0,05)$ para a produção de matéria seca da parte aérea, no primeiro corte, em função das doses de potássio na solução.

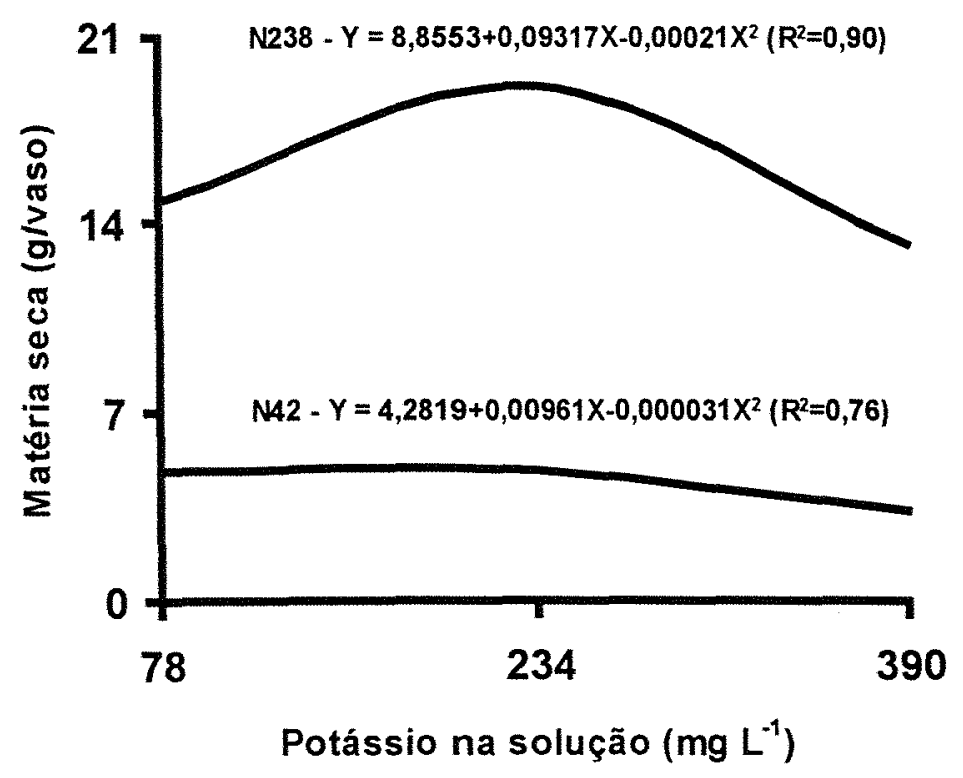

Figura 10 - Produção de matéria seca da parte aérea da braquiária decumbens, no primeiro corte, em função das doses de potássio dentro de duas doses de nitrogênio na solução nutritiva. 


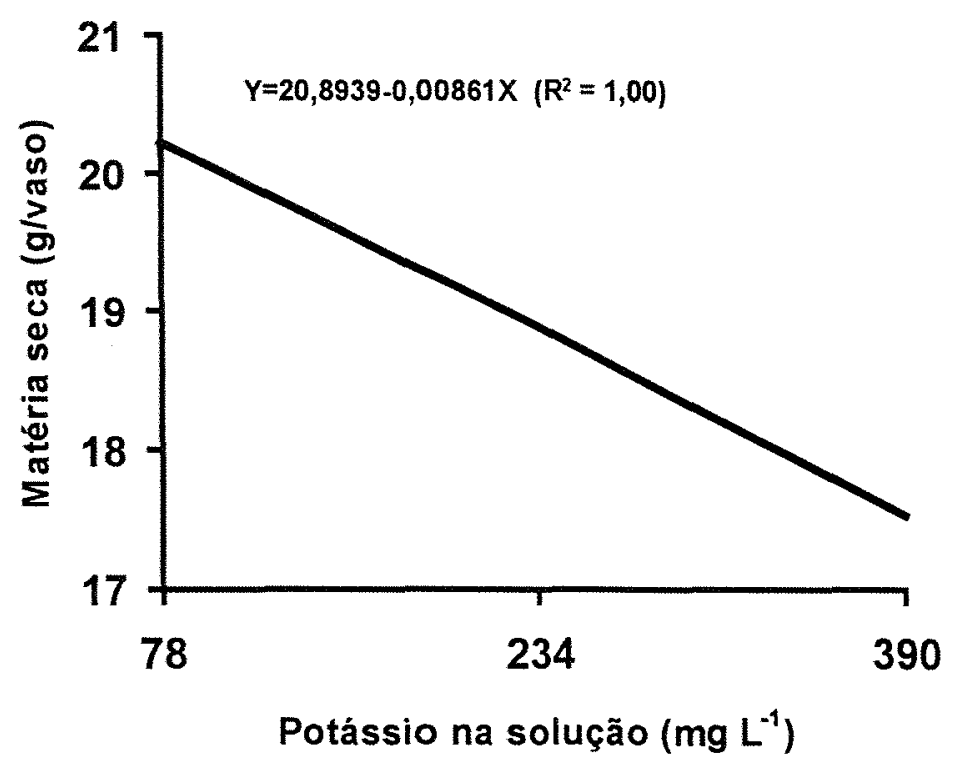

Figura 11 - Produção de matéria seca da parte aérea da braquiária decumbens, no primeiro corte, em função das doses de potássio dentro da dose de nitrogênio de $336 \mathrm{mg} \mathrm{L}^{-1}$ na solução nutritiva.

As doses de nitrogênio influenciaram significativamente $(P<0,01)$ a produção de matéria seca da parte aérea da braquiária no segundo crescimento, ajustando-se a resposta a modelo linear (Figura 12). Uma ilustração do efeito do nitrogênio no desenvolvimento da parte aérea desse capim é apresentada na Figura 16. 


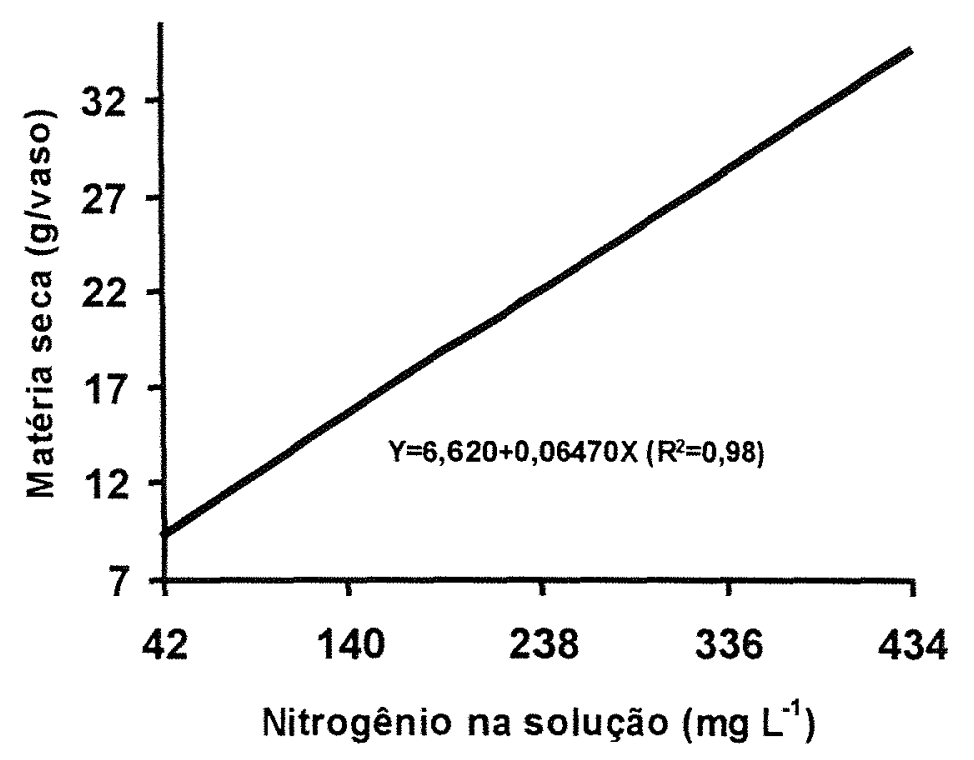

Figura 12 - Produção de matéria seca da parte aérea da braquiária decumbens, no segundo corte, em função das doses de nitrogênio na solução nutritiva.

No estudo do efeito das doses de potássio Faquin et al. (1995b) ressaltaram que a máxima produção de matéria seca na Brachiaria decumbens foi obtida com potássio na dose de $294 \mathrm{mg} \mathrm{kg}^{-1}$ de solo. Por sua vez Silva et al. (1995), para o capim-Tanzânia-1, verificaram que a máxima produção da parte aérea ocorreria com potássio em torno de $348 \mathrm{mg} \mathrm{L}^{-1}$ de solução nutritiva. Já Mattos et al. (1996), comparando as produções de matéria seca da braquiária decumbens, no primeiro e segundo corte, observaram aumentos de 68 e $222 \%$ em função das doses de potássio na solução e verificaram que a máxima produção de matéria seca ocorreu nas doses de potássio de 348 e $325 \mathrm{mg} \mathrm{L}^{-1}$.

No trabalho de Mattos (1997) o ponto de máxima produção da parte aérea da Brachiaria decumbens ocorreu além do limite estudado, com potássio na solução em $531 \mathrm{mg} \mathrm{L}^{-1}$ no primeiro corte e em $445 \mathrm{mg} \mathrm{L}^{-1}$ no segundo corte. $\mathrm{Na}$ Brachiaria brizantha esse mesmo autor obteve as máximas produções nas 
doses de 365 e $399 \mathrm{mg} \mathrm{L}^{-1}$ de potássio na solução, no primeiro e segundo corte, respectivamente.

Martim et al. (1997) trabalharam com os capins Coastcross-1 e Tifton 85 e verificaram que a produção de matéria seca da parte aérea, no terceiro corte, foi linearmente incrementada pela aplicação de nitrogênio e os maiores incrementos de produção ocorreram nas doses mais elevadas de potássio aplicadas ao solo (30 e $54 \mathrm{mg} \mathrm{kg}^{-1}$ ). Isto não foi observado por Monteiro et al. (1995), os quais verificaram que a omissão de potássio na Brachiaria brizantha Stapf. cv. Marandu não proporcionou redução significativa $(P>0,05)$ na produção de matéria seca em relação ao tratamento completo com $210 \mathrm{mg} \mathrm{L}^{-1}$ de nitrogênio na solução nutritiva.

\subsubsection{Inflorescências}

Através da análise de variância para a produção de matéria seca das inflorescências coletadas no primeiro crescimento das plantas, observouse que não foi significativa $(P>0,05)$ tanto a interação entre doses de nitrogênio e doses de potássio, como o efeito das doses de potássio, mas houve significância $(P<0,01)$ para o efeito das doses de nitrogênio.

O efeito das doses de nitrogênio na produção de massa das inflorescências foi representada por um modelo linear (Figura 13). Isto permite inferir que as doses de nitrogênio no substrato poderiam alterar beneficamente a produção de sementes desta forrageira.

Mecelis \& Oliveira (1984) trabalharam com Brachiaria humidicola com aplicação de nitrogênio ao solo em doses de 0,75 e $150 \mathrm{~kg} \mathrm{ha}^{-1} \mathrm{e}$ verificaram que a adubação nitrogenada aumentou significativamente $(P<0,01)$ a produção de matéria seca, o número total de perfilhos e de perfilhos florescidos por metro quadrado, a produção de sementes puras e a germinação das sementes. Constataram que a aplicação de nitrogênio proporcionou um 
aumento de $3,39 \mathrm{~kg}$ de sementes por quilograma de nitrogênio aplicado, na dose de nitrogênio de $75 \mathrm{~kg} \mathrm{ha}^{-1}$, para a segunda época de colheita.

Bianchine et al. (1987) conduziram um experimento cultivando o capim-Ramirez (Paspalum guenoarum Arech.) num Podzólico VermelhoAmarelo var. Laras, adubado com nitrogênio nas doses de 0,75 e $150 \mathrm{~kg} \mathrm{ha}^{-1}$, na forma de nitrocálcio. Verificaram, no segundo ano, que cada quilograma de nitrogênio proporcionou aumento de $2,9 \mathrm{~kg}$ de sementes puras na dose de nitrogênio de $75 \mathrm{~kg} \mathrm{ha}^{-1}$, para o segundo ano de colheita. Demonstraram que na dose mais elevada de nitrogênio (150 kg ha ${ }^{-1}$ ) obtiveram a maior produção de massa, mas observaram acamamento das plantas com prejuizos na produção de sementes.

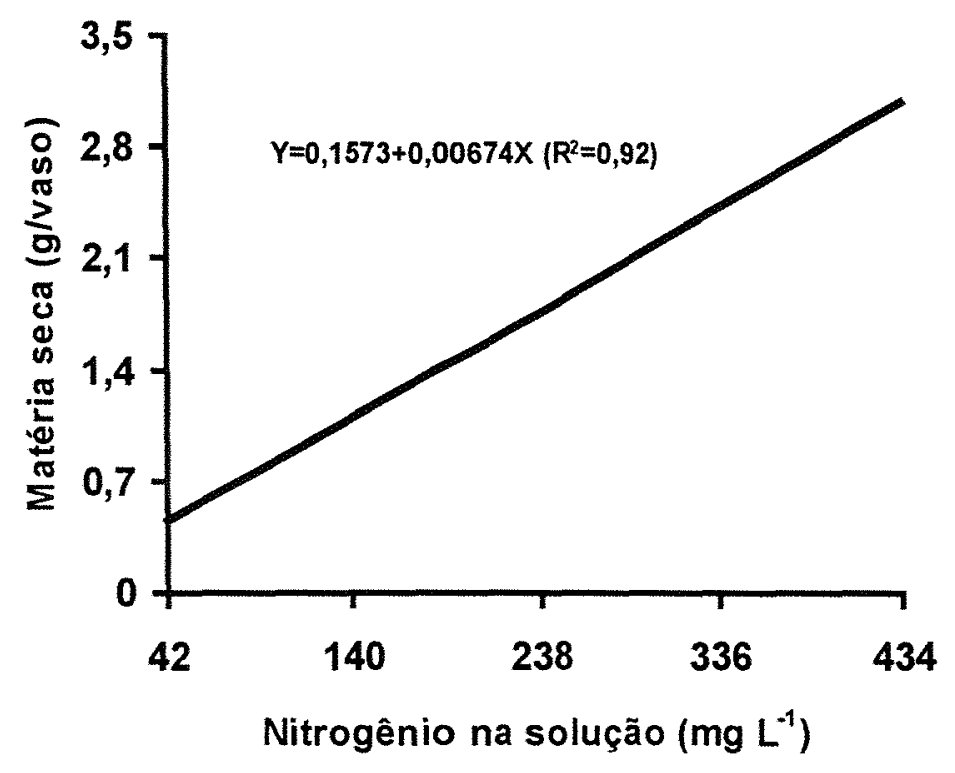

Figura 13 - Produção de matéria seca das inflorescências da braquiária decumbens, no primeiro crescimento, em função das doses de nitrogênio na solução nutritiva. 


\subsubsection{Raizes}

$\mathrm{Na}$ produção de matéria seca das raízes verificou-se que não foi significativa a interação entre doses de nitrogênio e doses de potássio, enquanto que houve significância para as doses de nitrogênio $(P<0,01)$ e para as doses de potássio $(P<0,05)$.

No estudo dos efeitos das doses de nitrogênio a produção de matéria seca das raízes da forrageira foi representada por uma equação de segundo grau (Figura 14 e ilustração na Figura 17). Através dessa equação verifica-se que a máxima produção seria obtida com nitrogênio na solução em dose superior à máxima utilizada no experimento e atingiria $605 \mathrm{mg} \mathrm{L}^{-1}$.

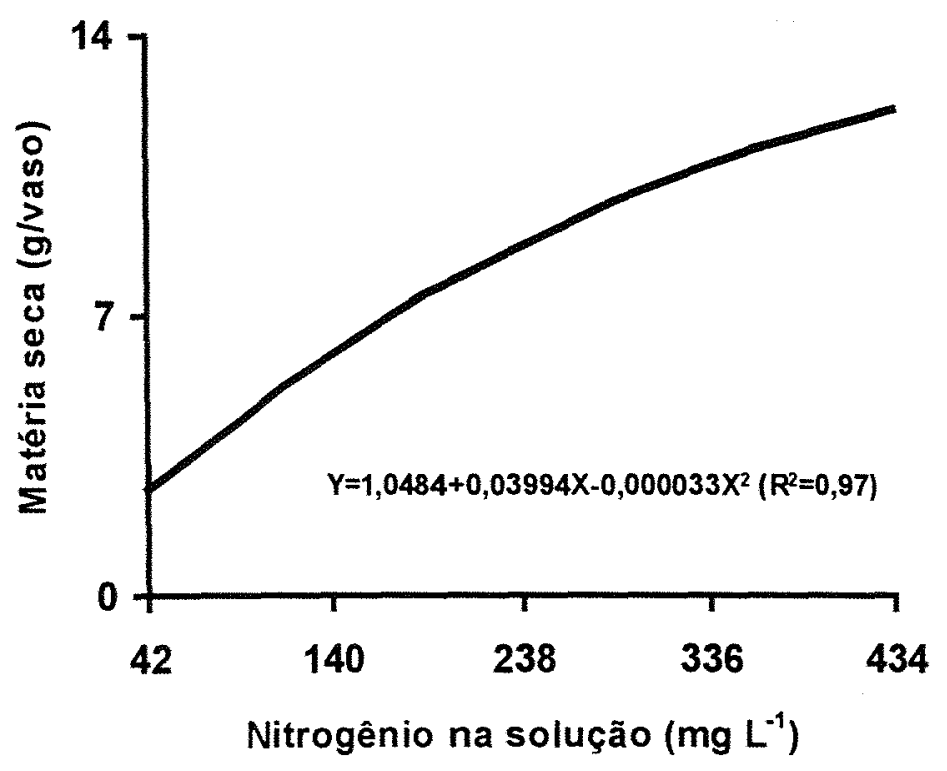

Figura 14 - Produção de matéria seca das raízes da braquiária decumbens em função das doses de nitrogênio na solução nutritiva.

Monteiro et al. (1995) verificaram na Brachiaria brizantha cv. Marandu que nos tratamentos onde foram omitidos nitrogênio e fósforo, 
ocorreram as maiores limitações ao desenvolvimento das plantas, tanto na produção de matéria seca na parte aérea como naquela das raízes. Acrescentaram que onde foi omitido o nitrogênio, inclusive na testemunha, as plantas alocaram maior parte de produção de biomassa para o sistema radicular. Corrêa \& Monteiro (1997) observaram nos capins Colonião, Tanzânia-1 e Vencedor efeitos significativos das doses de nitrogênio na produção de matéria seca das raízes. Martim (1997) observou que a máxima produção de matéria seca das raízes foi obtida no Tifton-85 nas doses de nitrogênio de $100 \mathrm{~kg} \mathrm{ha}^{-1}$ e de potássio $135 \mathrm{~kg} \mathrm{ha}^{-1}$ e no Coastcross-1 nas doses de nitrogênio $180 \mathrm{~kg} \mathrm{ha}^{-1}$ e de potássio $15 \mathrm{~kg} \mathrm{ha}^{-1}$, respectivamente.

O efeito das doses de potássio na produção de matéria seca das raízes ajustou-se a uma equação de primeiro grau. Pode-se observar na Figura 15 que à medida em que se elevou a dose de potássio diminuiu a produção de matéria seca das raizes da braquiária.

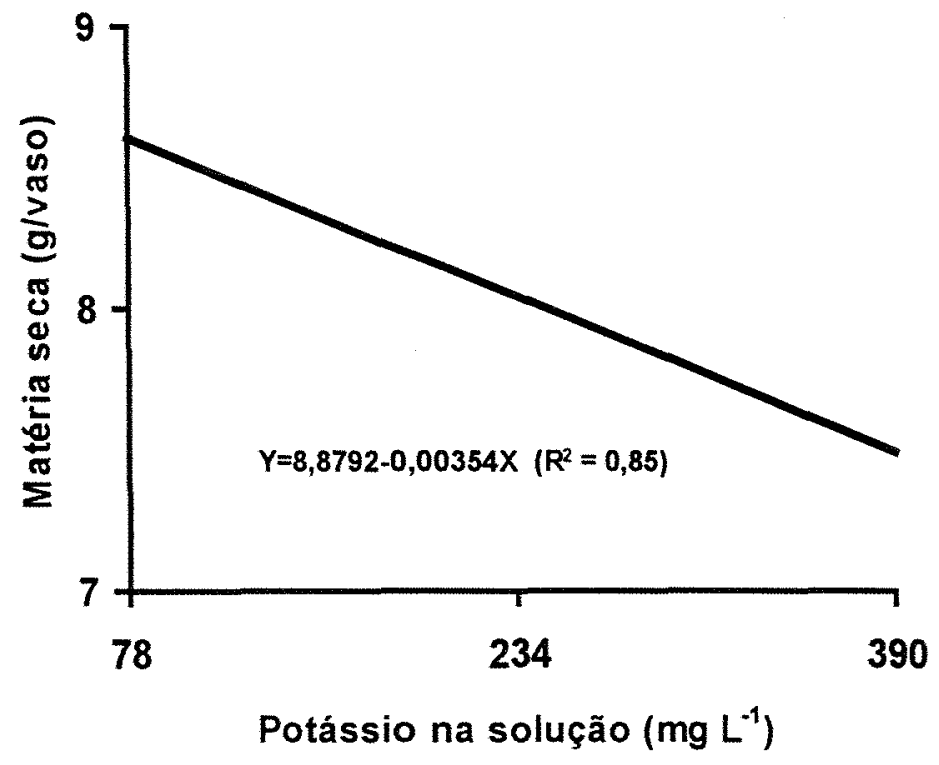

Figura 15 - Produção de matéria seca das raizes da braquiária decumbens, em função das doses de potássio na solução nutritiva. 


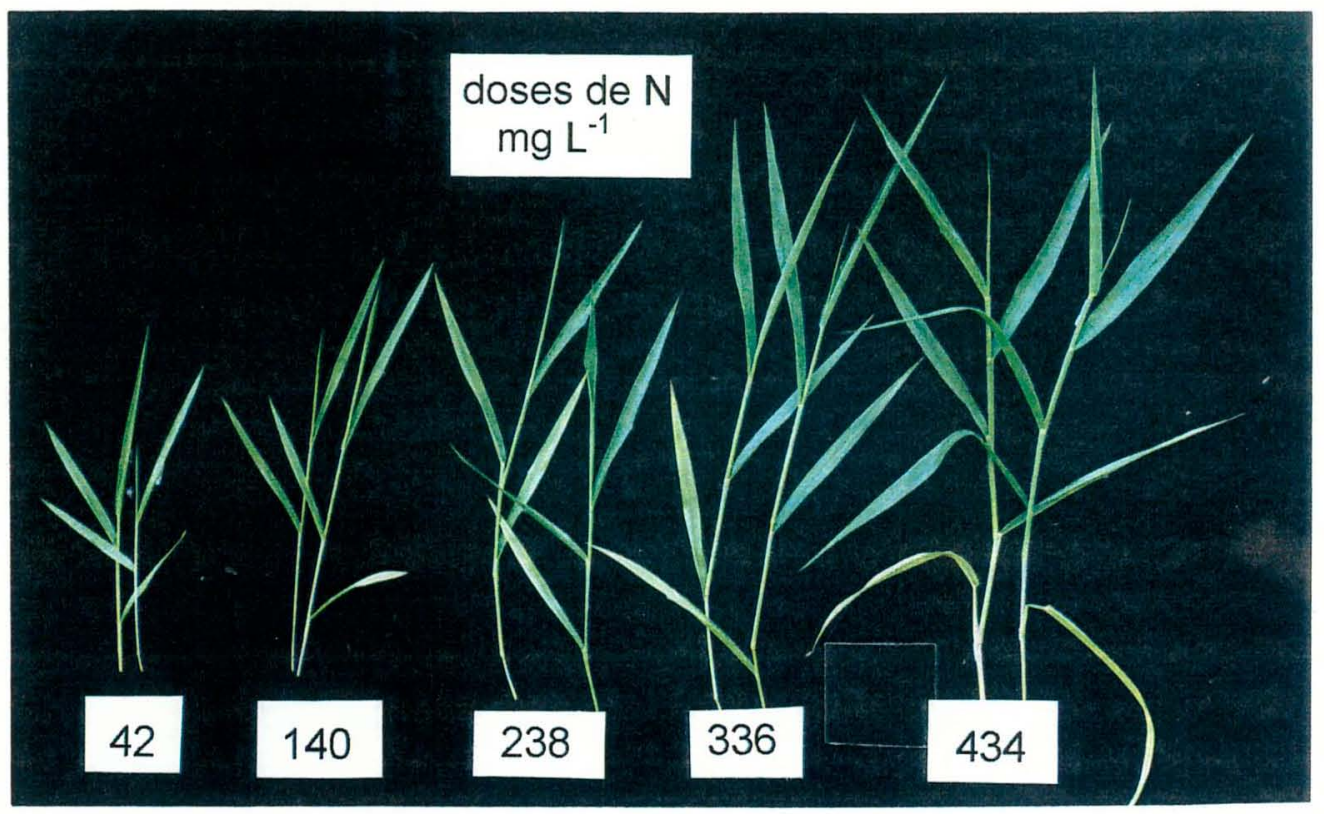

Figura 16 - Parte aérea de dois perfilhos no segundo crescimento da braquiária decumbens submetida a doses de nitrogênio solução em nutritiva.

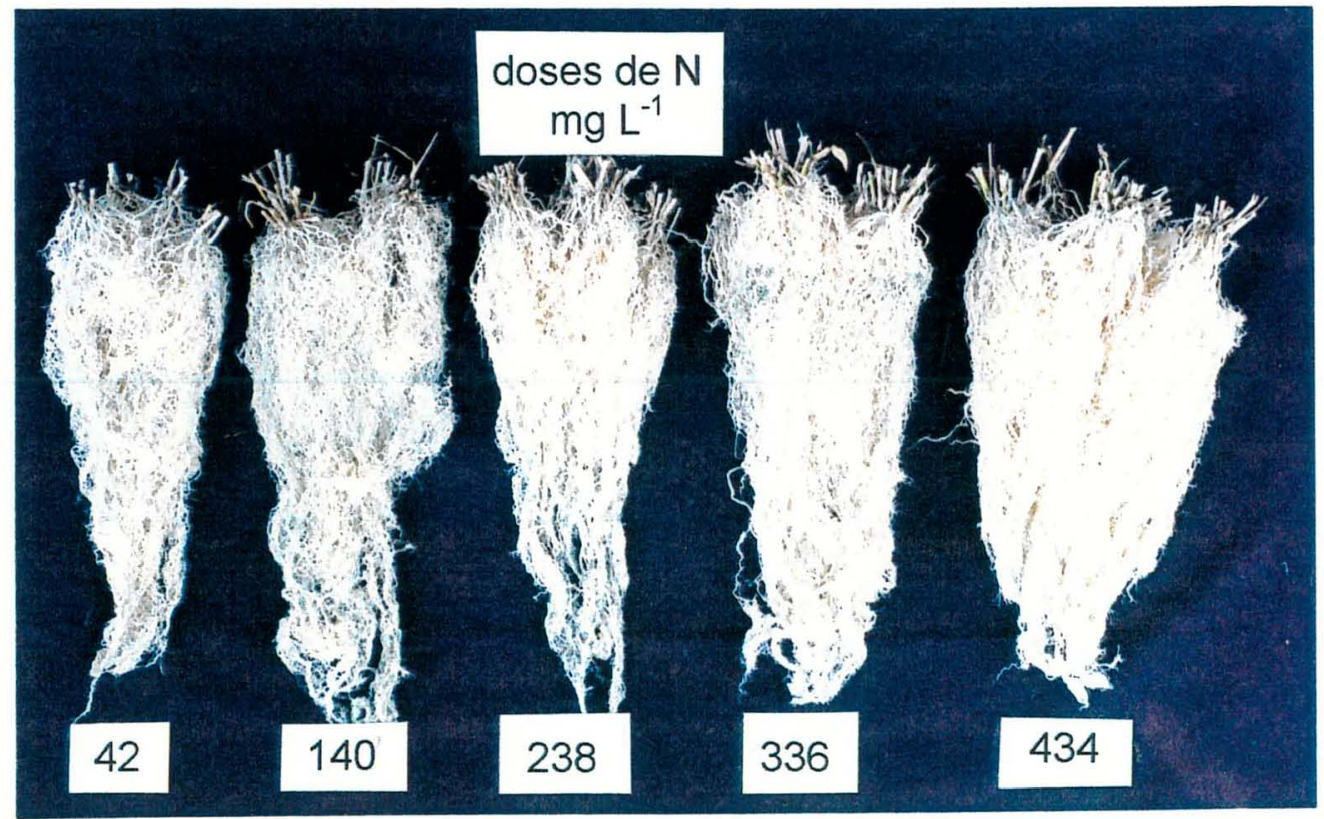

Figura 17 - Sistema radicular da braquiária decumbens submetida a nitrogênio doses de em solução nutritiva. 


\subsection{Número de perfilhos}

$\mathrm{Na}$ análise de variância para o número total de perfilhos por vaso, no primeiro crescimento, observou-se significância $(P<0,01)$ para a interação entre doses de nitrogênio e doses de potássio, enquanto no segundo crescimento verificou-se que não foi significativa $(P>0,05)$ essa interação.

Em função das doses de nitrogênio dentro de cada dose de potássio, no primeiro crescimento, foi constatado que o número de perfilhos variou com as doses de nitrogênio. Quando o potássio na solução nutritiva foi de $78 \mathrm{mg} \mathrm{L}^{-1}$ o número de perfilhos foi significativamente mais elevado nas doses de nitrogênio de 238, 336 e $434 \mathrm{mg} \mathrm{L}^{-1}$ que na dose de $42 \mathrm{mg} \mathrm{L}^{-1}$. Nesta dose de nitrogênio o número de perfilhos foi semelhante aquele da dose 140 $\mathrm{mg} \mathrm{L}^{-1}$, a qual por sua vez não diferiu do perfilhamento na dose de nitrogênio de $238 \mathrm{mg} \mathrm{L}^{-1}$ (Figura 18).

No primeiro período de crescimento quando o potássio na solução foi de $234 \mathrm{mg} \mathrm{L}^{-1}$, o número de perfilhos foi semelhante entre as doses de nitrogênio de 42 a $140 \mathrm{mg} \mathrm{L}^{-1}$, mas não foi incrementado à medida que se elevou o nitrogênio para as doses de 238 e $336 \mathrm{mg} \mathrm{L}^{-1}$. O número mais elevado de perfilhos ocorreu nas doses de nitrogênio de 434 e $336 \mathrm{mg} \mathrm{L}^{-1}$ (Figura 19).

$\mathrm{Na}$ solução nutritiva em que o potássio era de $390 \mathrm{mg} \mathrm{L}^{-1}$ o número de perfilhos foi semelhante entre as doses de nitrogênio de 42 e $140 \mathrm{mg} \mathrm{L}^{-1}$, mas não foi incrementado à medida que se elevou o nitrogênio para as doses 238 e $336 \mathrm{mg} \mathrm{L}^{-1}$. O número mais elevado de perfilhos ocorreu na dose de nitrogênio de $434 \mathrm{mg} \mathrm{L}^{-1}$ (Figura 20). 


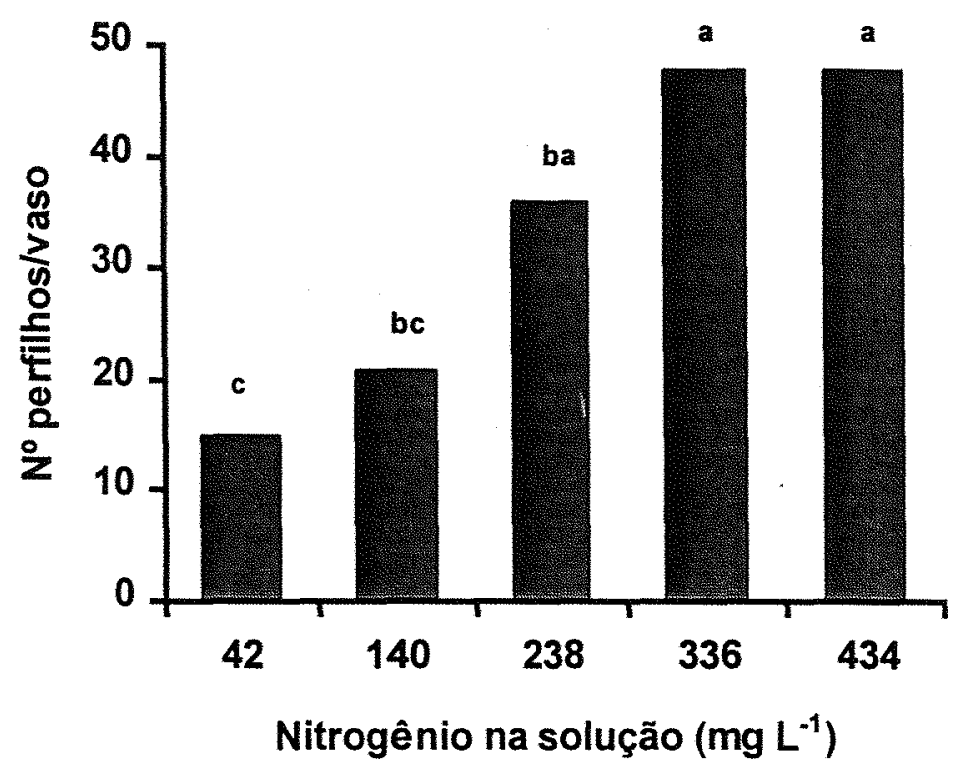

Figura 18 - Número de perfilhos nas cinco plantas de braquiária decumbens, no primeiro crescimento, em função das doses de nitrogênio dentro da dose de potássio $78 \mathrm{mg} \mathrm{L}^{-1}$ na solução nutritiva. Letras diferentes indicam diferença significativa ao nivel de $5 \%$ de probabilidade pelo teste de Tukey.

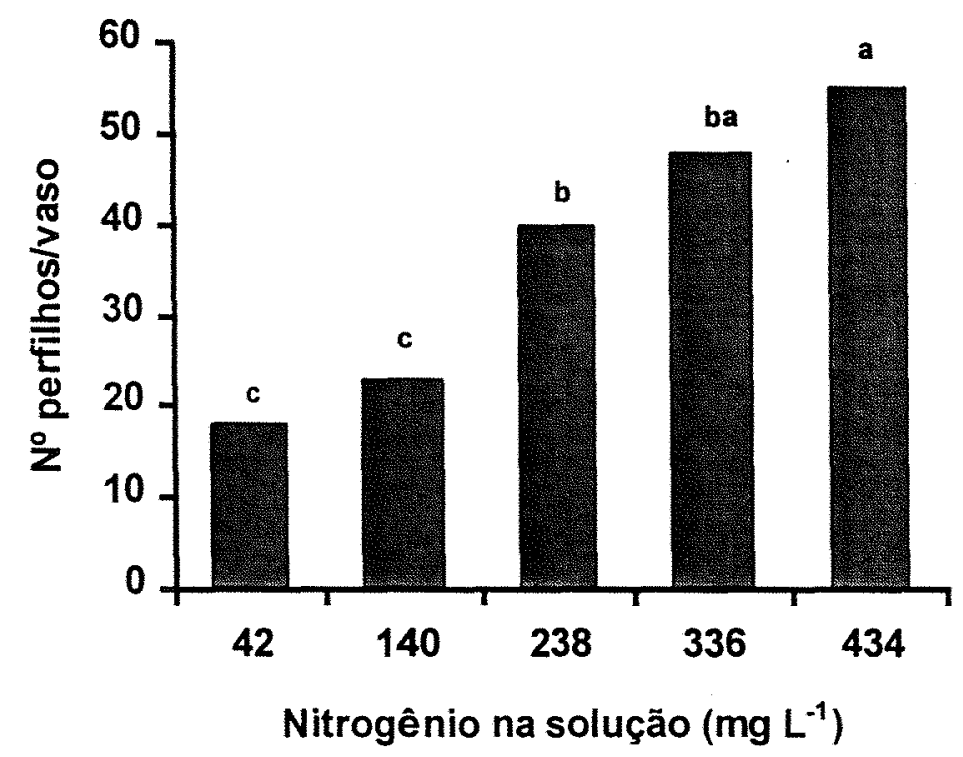

Figura 19 - Número de perfilhos nas cinco plantas de braquiária decumbens, no primeiro crescimento em função das doses de nitrogênio dentro da dose de potássio $234 \mathrm{mg} \mathrm{L}^{-1}$ na solução nutritiva. Letras diferentes indicam diferença significativa ao nivel de $5 \%$ de probabilidade pelo teste de Tukey. 


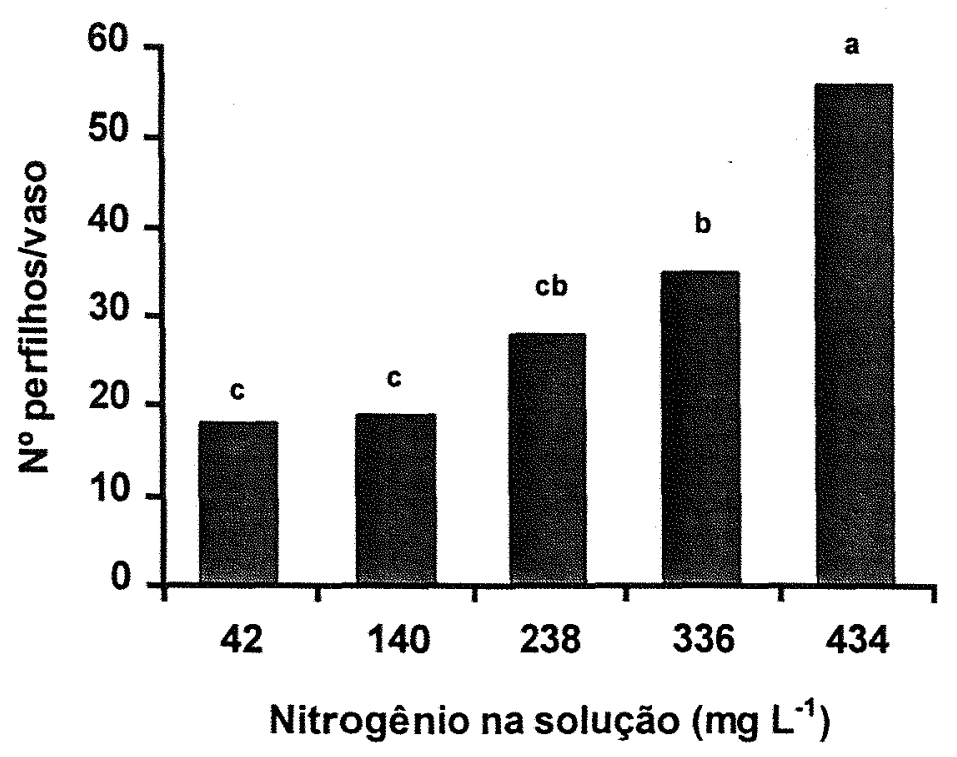

Figura 20 - Número de perfilhos nas cinco plantas de braquiária decumbens, no primeiro crescimento em função das doses de nitrogênio dentro da dose de potássio $390 \mathrm{mg} \mathrm{L}^{-1}$ na solução nutritiva. Letras diferentes indicam diferença significativa ao nivel de $5 \%$ de probabilidade pelo teste de Tukey.

No estudo dos efeitos das doses de potássio dentro das doses de nitrogênio, no primeiro crescimento, revelou-se significância $(P<0,05)$ para o potássio quando o nitrogênio na solução foi de 238 e $336 \mathrm{mg} \mathrm{L}^{-1}$. Nas doses 42 , 140 e $434 \mathrm{mg} \mathrm{L}^{-1}$ de nitrogênio na solução, não se verificou significância $(P>0,05)$ para o potássio em termos de número de perfilhos totais nas plantas.

Quando o nitrogênio na solução foi de $238 \mathrm{mg} \mathrm{L}^{-1}$ o número total de perfilhos nas plantas não variou significativamente da dose de potássio de 78 $\mathrm{mg} \mathrm{L}^{-1}$ para a dose $234 \mathrm{mg} \mathrm{L}^{-1}$, mas foi significativamente mais baixo na dose de $390 \mathrm{mg} \mathrm{K} \mathrm{L}^{-1}$ em relação às outras duas doses de potássio na solução nutritiva (Figura 21). 


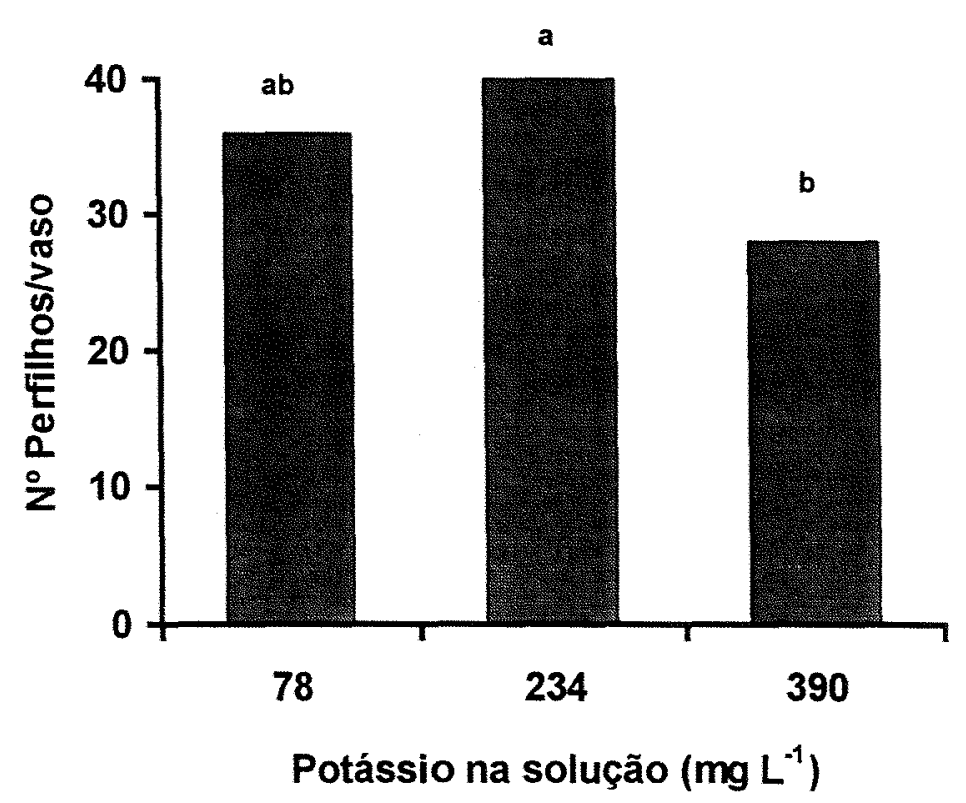

Figura 21 - Número de perfilhos nas cinco plantas de Brachiaria decumbens Stapf cv. Basilisk, no primeiro crescimento, em função das doses de potássio dentro da dose de nitrogênio $238 \mathrm{mg} \mathrm{L}^{-1}$ na solução nutritiva. Letras diferentes indicam diferença significativa ao nivel de $5 \%$ de probabilidade pelo teste de Tukey.

Quando o nitrogênio na solução foi de $336 \mathrm{mg} \mathrm{L}^{-1}$ o número total de perfilhos nas plantas não variou significativamente da dose de potássio $78 \mathrm{mg} \mathrm{L}^{-1}$ para a dose $234 \mathrm{mg} \mathrm{L}^{-1}$, mas foi significativamente mais baixo na dose de $390 \mathrm{mg} \mathrm{L}^{-1}$ em relação às outras doses de potássio na solução nutritiva (Figura 22). 


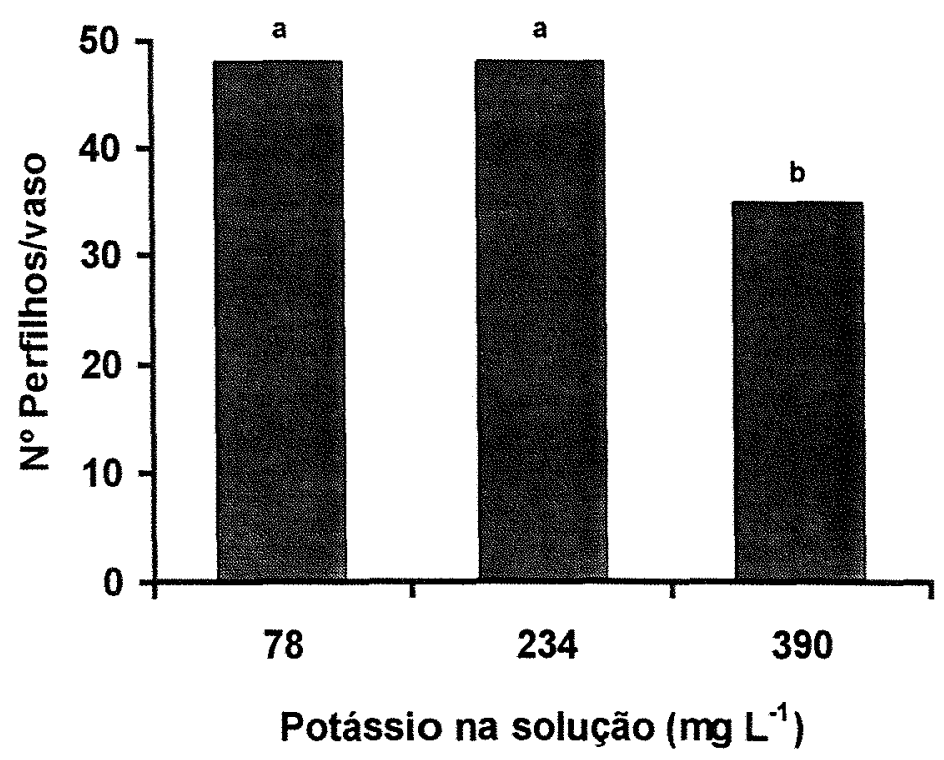

Figura 22 - Número de perfilhos nas cinco plantas de braquiária decumbens, no segundo crescimento, em função da dose de nitrogênio $336 \mathrm{mg} \mathrm{L}^{-1}$ na solução nutritiva. Letras diferentes indicam diferença significativa ao nivel de 5 $\%$ de probabilidade pelo teste de Tukey.

No segundo período de crescimento foi constatado que o número total de perfilhos por vaso aumentou à medida em que se elevou a dose de nitrogênio. $O$ número de perfilhos foi mais elelvado nas doses de nitrogênio de 336 e $434 \mathrm{mg} \mathrm{L}^{-1}$ (Figura 23). 


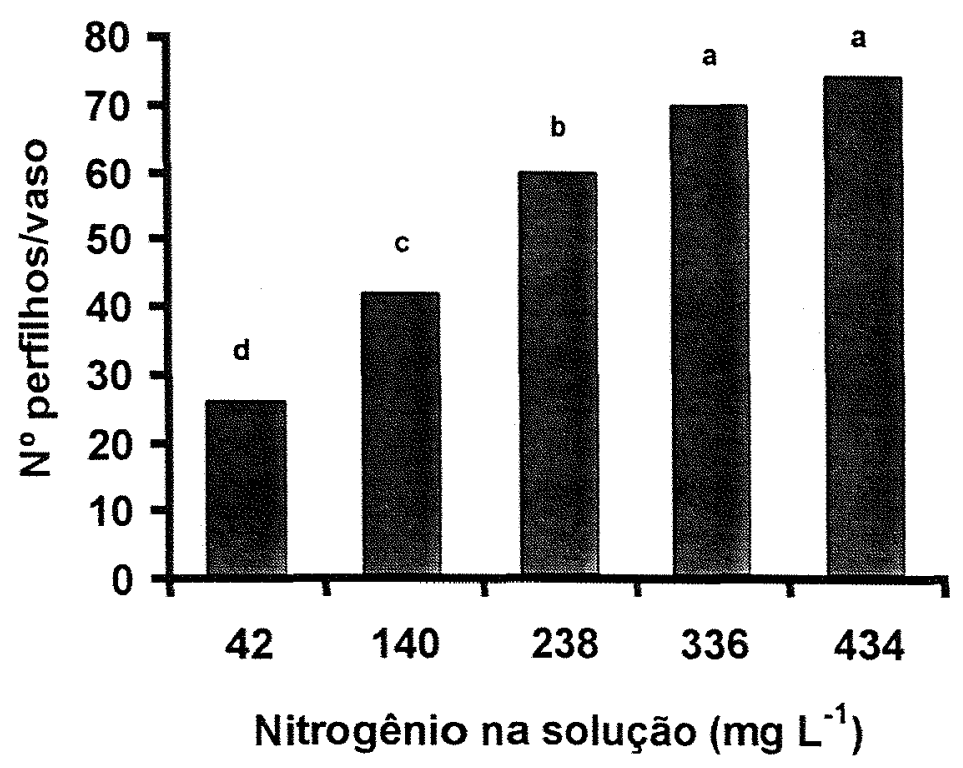

Figura 23 - Número de perfilhos nas cinco plantas de braquiária decumbens, no segundo crescimento, em função das doses de nitrogênio na solução nutritiva. Letras diferentes indicam diferença significativa ao nivel de $5 \%$ de probabilidade pelo teste de Tukey.

$\mathrm{Na}$ avaliação do número total de perfilhos por vaso, no segundo crescimento, empregando as doses de potássio na solução nutritiva, foi constatado que o número de perfilhos não variou significativamente da dose de potássio $78 \mathrm{mg} \mathrm{L}^{-1}$ para a dose $234 \mathrm{mg} \mathrm{L}^{-1}$. Quando a dose de potássio foi incrementada de 234 para $390 \mathrm{mg} \mathrm{L}^{-1}$ (Figura 24). 


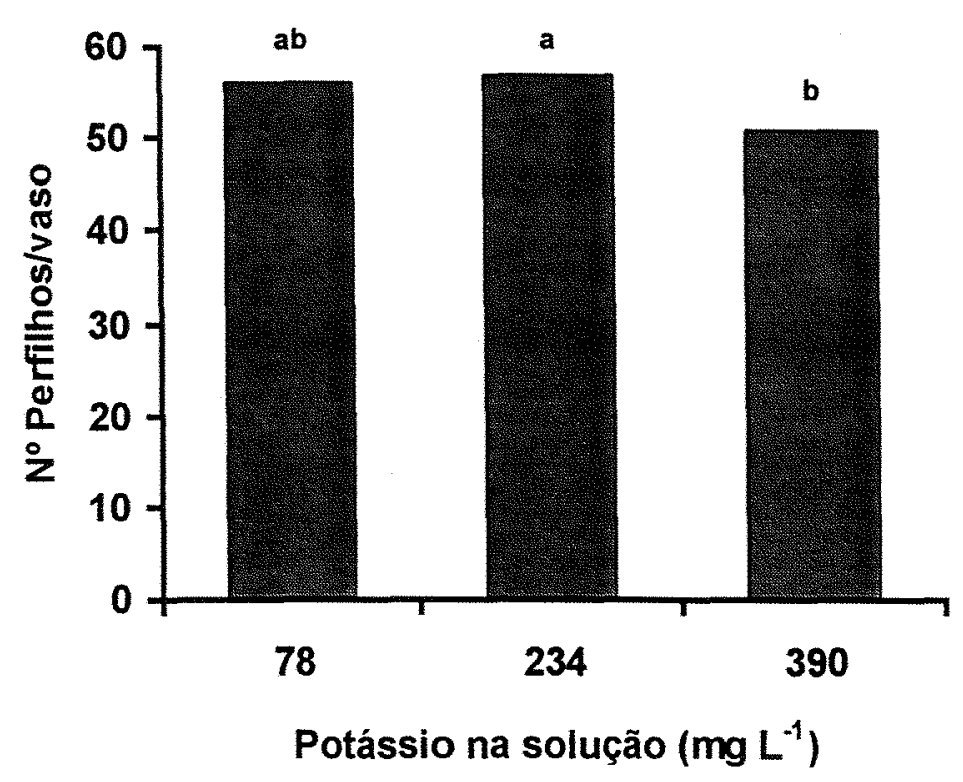

Figura 24 - Número de perfilhos nas cinco plantas de braquiária decumbens, no segundo crescimento, em função das doses de potássio na solução nutritiva. Letras diferentes indicam diferença significativa ao nivel de $5 \%$ de probabilidade pelo teste de Tukey.

A capacidade de produzir perfilhos é caracteristico das gramíneas. $O$ perfilho é considerado a unidade estrutural e produtiva das forrageiras (Langer, 1974), portanto é desejável uma grande quantidade de perfilhos para assegurar a persistência das mesmas.

A densidade populacional de perfilhos é freqüentemente avaliada e utilizada como um indicador de vigor ou persistência em pastagens, ou como um componente de resposta, como por exemplo à aplicação de fertilizantes nitrogenados (Davies, 1974). Se a densidade de perfilhos é muito baixa, pode haver limitação ao crescimento potencial por insuficiência no número de folhas em expansão.

Abreu (1994) verificou no capim-Tanzânia-1 a tendência desta forrageira em aumentar a quantidade de perfilhos além da dose de nitrogênio de $210 \mathrm{mg} \mathrm{L}^{-1}$. Corrêa (1996) observou, em três cultivares de Panicum maximum, que o número de perfilhos, no primeiro e segundo 
crescimento, aumentou da dose $42 \mathrm{mg} \mathrm{L}^{-1}$ de nitrogênio para a $210 \mathrm{mg} \mathrm{L}^{-1}$, não variando entre 210 e $378 \mathrm{mg} \mathrm{L}^{-1}$. Santos (1997) constatou que o número de perfilhos na Brachiaria decumbens, no primeiro crescimento, aumentou significativamente até $378 \mathrm{mg} \mathrm{L}^{-1}$ de nitrogênio na solução nutritiva, enquanto no segundo crescimento a quantidade de perfilhos foi crescente com as doses de nitrogênio avaliadas. Resultados semelhantes, confirmando a importância do nitrogênio no perfilhamento de algumas gramineas forrageiras, foram encontrados por Werner et al. (1967), Santos et al. (1995) e Corrêa et al. (1997).

O número médio de perfilhos no primeiro crescimento foi menor que aquele do segundo crescimento pois na primeira fase a planta estava em estabelecimento e com formação do sistema radicular.

\subsection{Concentração dos macronutrientes nas lâminas de folhas novas}

\subsubsection{Nitrogênio}

A concentração de nitrogênio nas lâminas de folhas novas mostrou significância $(P<0,05)$ no primeiro e no segundo corte para a interação entre doses de nitrogênio e doses de potássio.

No estudo das doses de nitrogênio dentro de cada dose de potássio, no primeiro crescimento, verificou-se efeito significativo $(P<0,05)$ para 0 nitrogênio dentro da dose de potássio de $234 \mathrm{mg} \mathrm{L}^{-1}$, na qual os resultados se ajustaram a um modelo quadrático (Figura 25). Com o potássio em 78 e 390 $\mathrm{mg} \mathrm{L}^{-1}$ não se verificou efeito significativo $(P>0,05)$ para a concentração de nitrogênio nas lâminas de folhas novas, no primeiro crescimento, em função das doses de nitrogênio na solução. Para o efeito das doses de nitrogênio dentro de cada dose de potássio, no segundo crescimento, a concentração de 
nitrogênio não variou significativamente $(P>0,05)$ nas lâminas de folhas novas da braquiária.

No primeiro corte ocorreu significância $(P<0,01)$ para o efeito de doses de potássio dentro da dose $238 \mathrm{mg} \mathrm{L}^{-1}$ de nitrogênio, quando uma equação de segundo grau representou este efeito (Figura 26). Nas doses 42 , 140,336 e $434 \mathrm{mg} \mathrm{L}^{-1}$ de nitrogênio não se verificou efeito significativo $(P>0,05)$ para a concentração de nitrogênio no tecido das lâminas de folhas novas, no primeiro corte, em função das doses de potássio na solução.

No material colhido no segundo corte, foi verificada significância $(\mathrm{P}<0,01)$ para o potássio na dose $140 \mathrm{mg} \mathrm{L}^{-1}$ de nitrogênio, sendo a resposta ajustada a modelo linear. Dentro da dose $336 \mathrm{mg} \mathrm{L}^{-1}$ de nitrogênio constatou-se significância $(P<0,05)$ para o efeito do potássio, situação em que uma equação de primeiro grau representou esse efeito (Figura 27).

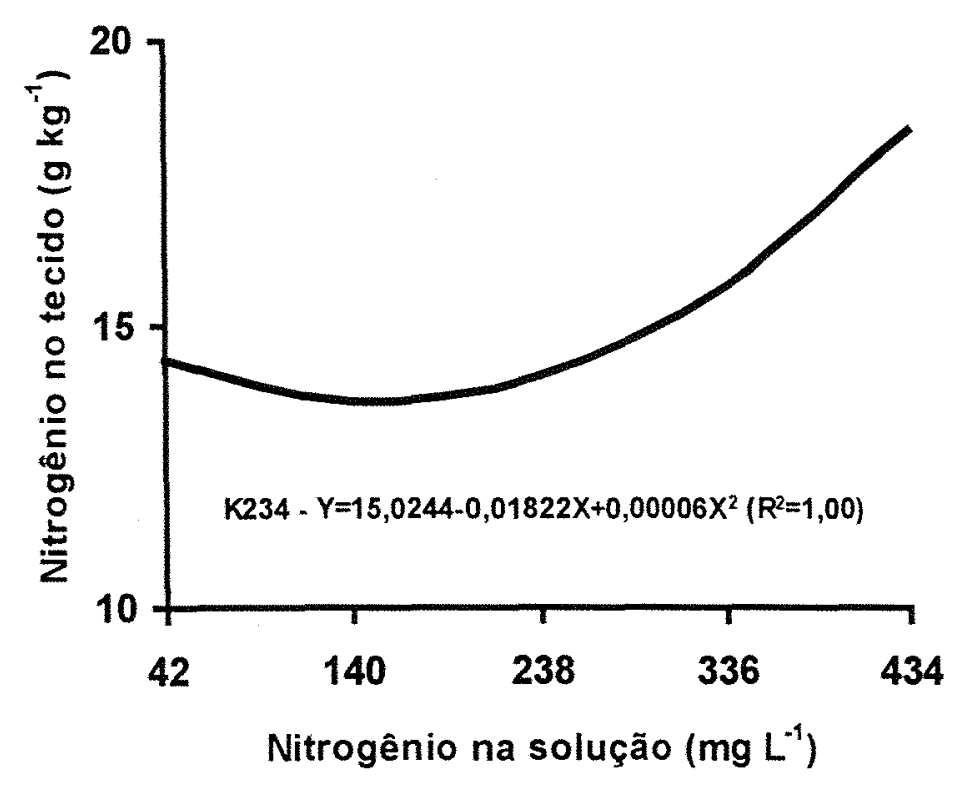

Figura 25 - Concentração de nitrogênio nas lâminas de folhas novas, no primeiro corte da braquiária decumbens, em função das doses de nitrogênio na solução nutritiva. 


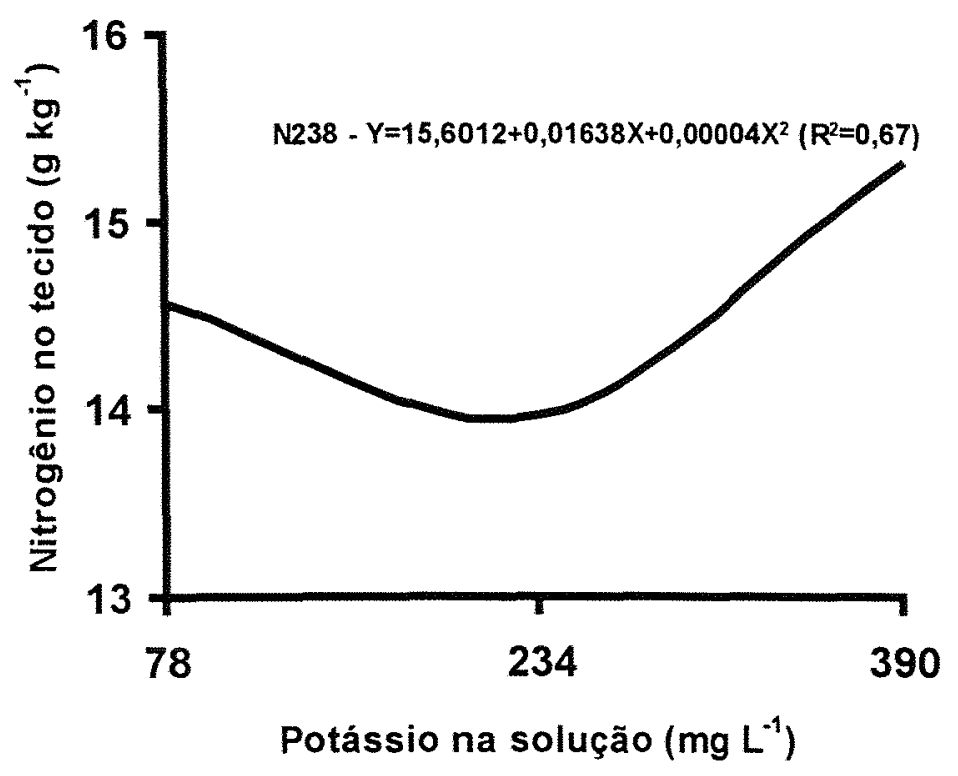

Figura 26 - Concentração de nitrogênio nas lâminas de folhas novas, no primeiro corte da braquiária decumbens, em função das doses de potássio na solução nutritiva.

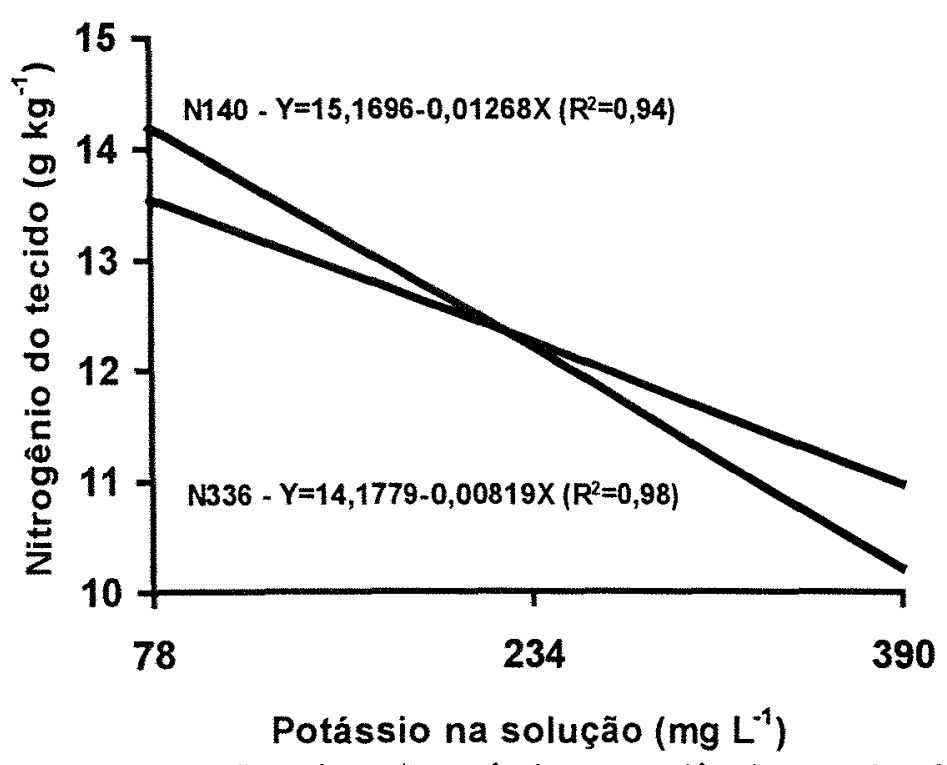

Figura 27 - Concentração de nitrogênio nas lâminas de folhas novas, no segundo corte da braquiária decumbens, em função das doses de potássio dentro das doses de nitrogênio 140 e $336 \mathrm{mg} \mathrm{L}^{-1}$ na solução nutritiva. 
Carvalho et al. (1991) observaram que a concentração de nitrogênio no capim-braquiária foi incrementada linearmente com a aplicação dos níveis de nitrogênio, atingindo valores de 17 e $21 \mathrm{~g} \mathrm{~kg}^{-1}$; no entanto, diminuíram com o aumento da dose de potássio na adubação, em decorrência do aumento da produção de matéria seca. Na ausência de aplicação de nitrogênio, a concentração de nitrogênio na forragem variou de 8 a $14 \mathrm{~g} \mathrm{~kg}^{-1}$. Resultados semelhantes foram verificados por Martim et al. (1997), os quais constataram as mais elevadas concentrações de nitrogênio nas mais baixas doses de potássio aplicadas ao solo.

\subsubsection{Fósforo}

$\mathrm{Na}$ análise de variância da concentração de fósforo nas lâminas de folhas novas no primeiro e segundo crescimento observou-se que não foi significativa $(P>0,05)$ a interação nitrogênio e potássio.

No estudo dos efeitos das doses de nitrogênio observou-se que a concentração de fósforo nas lâminas de folhas novas da braquiária, no primeiro e no segundo crescimento, foi representada por modelo linear (Figura 28).

Quanto ao efeito das doses de potássio na concentração de fósforo nas lâminas de folhas novas, o mesmo ajustou-se à equação de primeiro grau, tanto no material vegetal do primeiro como do segundo corte (Figura 29). 


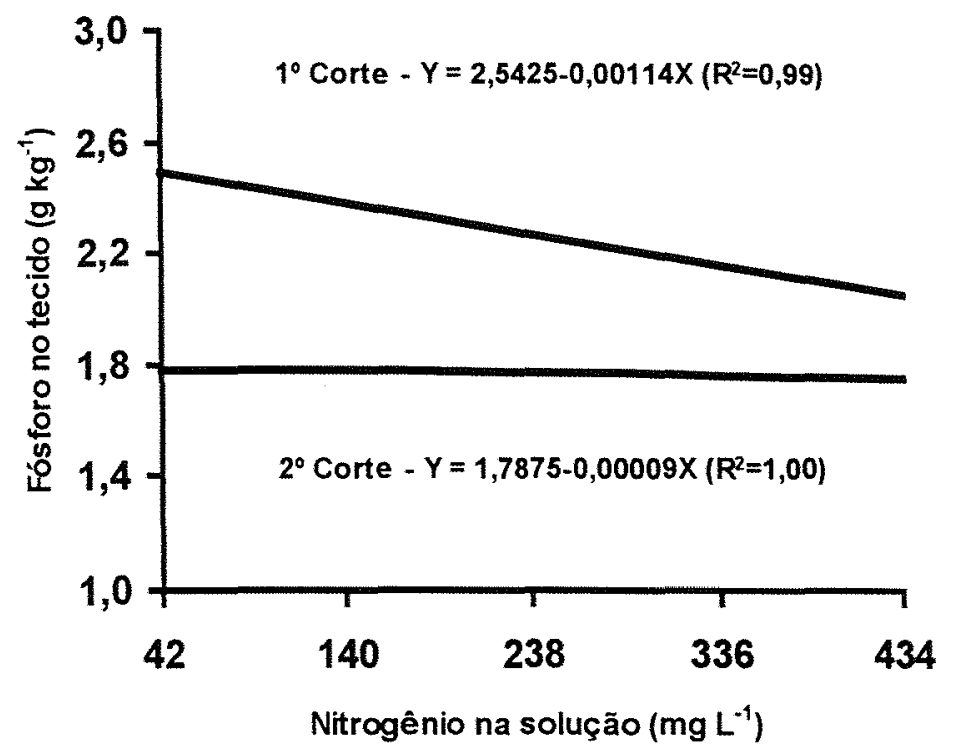

Figura 28 - Concentração de fósforo nas lâminas de folhas novas, no primeiro e segundo corte, da braquiária decumbens, em função das doses de nitrogênio na solução nutritiva.

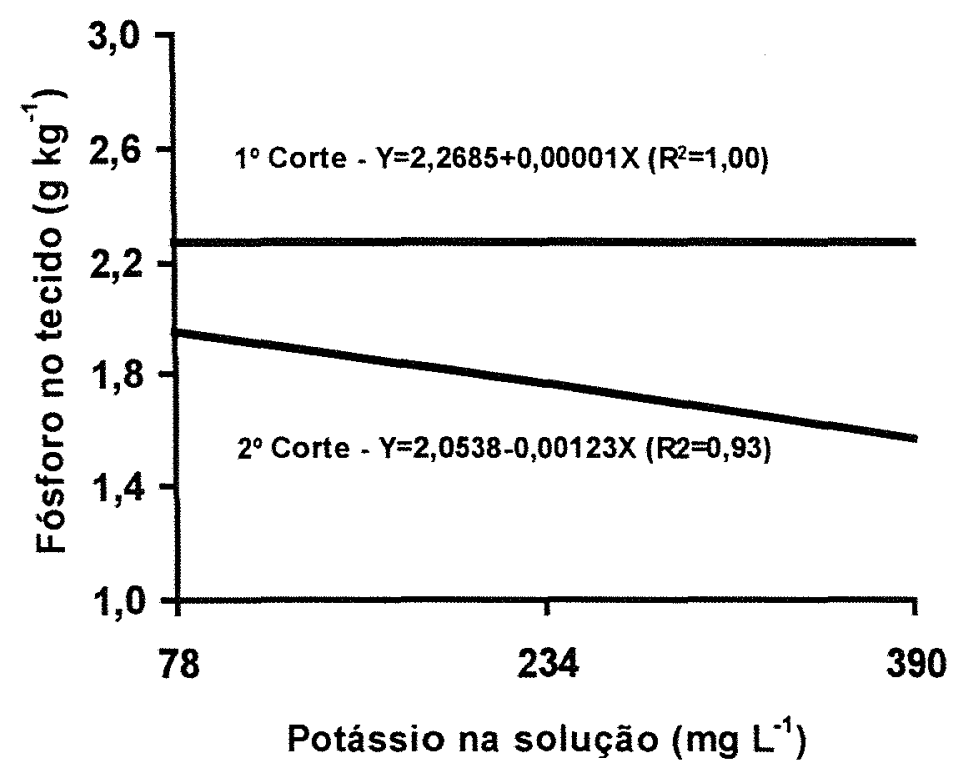

Figura 29 - Concentração de fósforo nas lâminas de folhas novas, no primeiro e segundo corte, da braquiária decumbens, em função das doses de potássio na solução nutritiva. 
Os resultados evidenciam que a concentração de fósforo nas lâminas de folhas novas foi mais baixa nas mais altas doses de nitrogênio. Entretanto, em função das doses de potássio na solução, houve decréscimo na concentração de fósforo nas lâminas de folhas novas da braquiária, no segundo corte. Semelhantes observações foram constatadas por Fernandes et al. (1985) em Brachiaria decumbens, quando aplicaram $30 \mathrm{~kg} \mathrm{ha}^{-1}$ de $\mathrm{K}_{2} \mathrm{O}$ e 20 $\mathrm{kg} \mathrm{ha}^{-1}$ de nitrogênio e obtiveram a mais baixa concentração de fósforo na parte aérea da forrageira.

Hernández \& Cárdenas (1990) verificaram que o teor máximo de fósforo encontrado no capim-estrela (Cynodon nlemfuensis cv. jamaicano) foi de $2,1 \mathrm{~g} \mathrm{~kg}^{-1}$ e $1,8 \mathrm{~g} \mathrm{~kg}^{-1}$, no primeiro e segundo ano respectivamente, na dose mais baixa de nitrogênio ou quando este não foi suprido. Martim (1997) observou que a concentração de fósforo, no primeiro crescimento, foi maior em Tifton $85\left(1,1 \mathrm{~g} \mathrm{~kg}^{-1}\right)$ do que em Coastcross $\left(0,8 \mathrm{~g} \mathrm{~kg}^{-1}\right)$ e estes valores foram inferiores aos observados por Pedreira \& Mattos (1981), que encontraram em Coastcross 1, teor de fósforo de $2,5 \mathrm{~g} \mathrm{~kg}^{-1}$. Monteiro et al. (1995), cultivando Brachiaria brizantha Stapf. cv. Marandu em solução nutritiva com omissões de macronutrientes, 50 dias após o transplante, observaram teores de fósforo de $2,4 \mathrm{~g} \mathrm{~kg}^{-1}$ no tratamento completo e $3,7 \mathrm{~g} \mathrm{~kg}^{-1}$ de fósforo na omissão de potássio.

\subsubsection{Potássio}

A interação entre doses de nitrogênio e doses de potássio não foi significativa $(P>0,05)$ para a concentração de potássio nas lâminas de folhas novas da braquiária, no material vegetal de ambos os crescimentos do capim. As doses de nitrogênio influenciaram significativamente $(P<0,01)$ na concentração de potássio no tecido vegetal, provenientes do primeiro e 
segundo corte, enquanto as doses de potássio também tiveram significância $(P<0,01)$ em tal concentração, nas lâminas de folhas coletadas tanto no primeiro como no segundo corte da forrageira.

$O$ efeito das doses de nitrogênio no primeiro e segundo corte foi representado por modelo quadrático (Figura 30 ), enquanto o efeito das doses de potássio em ambos os crescimentos ajustou-se a modelo linear (Figura 31).

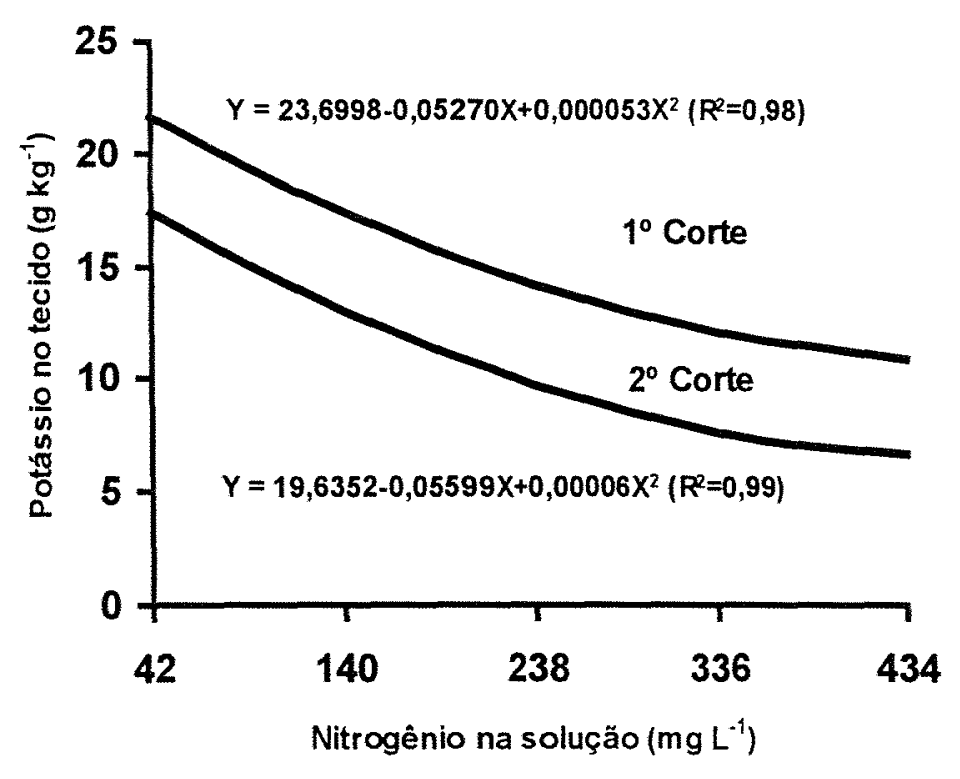

Figura 30 - Concentração de potássio nas lâminas de folhas novas, no primeiro e segundo corte, da braquiária decumbens, em função das doses de nitrogênio na solução nutritiva.

Pode-se observar efeito de diluição uma vez que na menor dose de nitrogênio foi obtida a maior concentração de potássio no tecido das lâminas de folhas novas. 


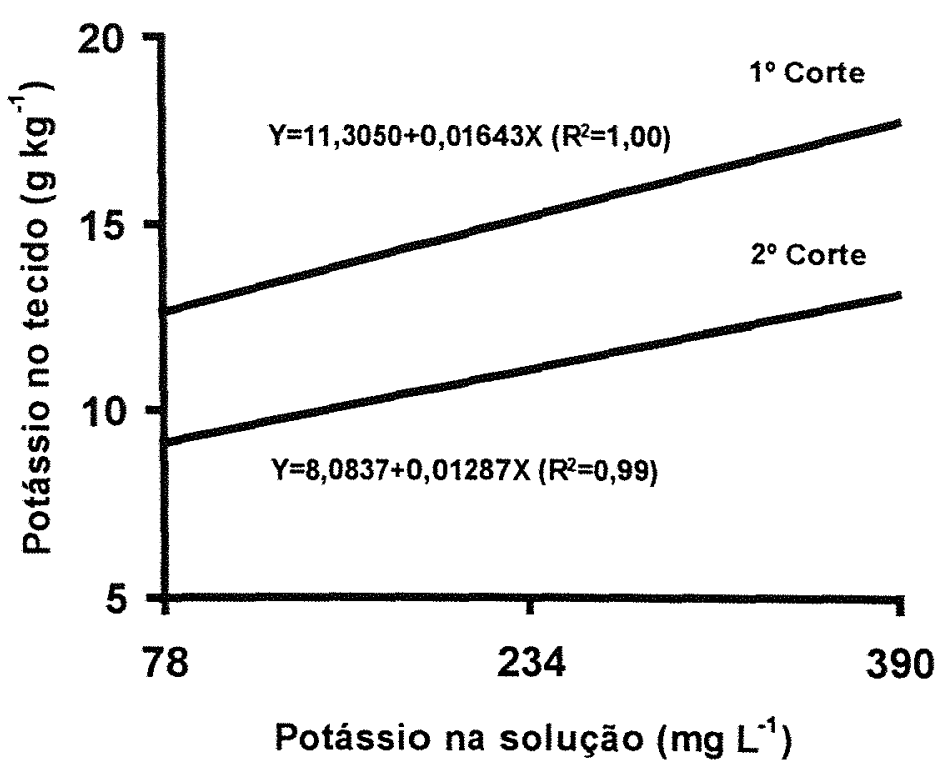

Figura 31 - Concentração de potássio nas lâminas de folhas novas, no primeiro e segundo corte, da braquiária decumbens, em função das doses de potássio na solução nutritiva.

Observou-se que nas mais altas doses de nitrogênio houve redução no teor de potássio na matéria seca da braquiária. Por outro lado, o teor de potássio nas lâminas de folhas novas aumentou à medida que foram incrementadas as doses de potássio. Resultados semelhantes foram obtidos por Fernandes et al. (1985), que constataram uma redução no teor de potássio na parte aérea do capim-braquiária da ordem de 30 e $32 \%$, quando elevaram as doses de nitrogênio de 20 para $40 \mathrm{~kg} \mathrm{ha}^{-1}$ respectivamente, em relação à não aplicação de adubo nitrogenado. Quanto às doses de potássio estudadas, verificou-se acréscimo na concentração de potássio na parte aérea do capimbraquiária da ordem de 40 e $79 \%$, para as doses empregadas (30 e $60 \mathrm{~kg} \mathrm{ha}^{-1}$ de $\mathrm{K}_{2} \mathrm{O}$, respectivamente).

França \& Haag (1985) encontraram em capim-Tobiatã (Panicum maximum Jacq.) teores de potássio nas folhas novas no tratamento completo da ordem de $31,1 \mathrm{~g} \mathrm{~kg}^{-1}$, o qual diminuiu a $7,5 \mathrm{~g} \mathrm{~kg}^{-1}$ quando foi omitido o potássio na solução nutritiva. Monteiro et al. (1995), cultivando a Brachiaria brizantha cv. Marandu cultivada em solução nutritiva, observaram teores de 
potássio no tratamento completo da ordem de $28,0 \mathrm{~g} \mathrm{~kg}^{-1}$ e quando foi omitido o potássio na ordem de $4,3 \mathrm{~g} \mathrm{~kg}^{-1}$. Mattos (1997), estudando a Brachiaria decumbens Stapf., verificou um aumento na concentração de potássio nas lâminas das folhas novas de 5,61 a $29,63 \mathrm{~g} \mathrm{~kg}^{-1}$ no primeiro corte, em função do aumento do potássio na solução. Constatou ainda que com o emprego de $414 \mathrm{mg} \mathrm{L}^{-1}$ de potássio na solução obteve a máxima concentração de potássio nas lâminas foliares da forrageira.

Gallo et al. (1974) coletaram 249 amostras de forrageiras e observaram que 0 teor de potássio em todas esteva acima de $8,0 \mathrm{~g} \mathrm{~kg}^{-1}$. Ainda constataram que cerca de $74 \%$ do total de amostras situaram-se na faixa de concentração de 12,0 a $28,0 \mathrm{~g} \mathrm{~kg}^{-1}$ de potássio, valores relativamente altos em comparação com a exigência do animal (na ordem de $6,0 \mathrm{~g} \mathrm{~kg}^{-1}$ como mínimo adequado para bovinos).

\subsubsection{Cálcio}

A interação entre doses de nitrogênio e doses de potássio, em termos de concentração de cálcio no tecido das lâminas de folhas novas, não foi significativa $(P>0,05)$ no primeiro crescimento mas foi significativa $(P<0,05)$ no material coletado ao final do segundo crescimento das plantas. Verificou-se significância $(P<0,01)$ para as doses de nitrogênio e $(P<0,01)$ para as doses de potássio, no segundo crescimento.

No desdobramento da interação, para nitrogênio dentro de doses potássio verificou-se efeito significativo $(P<0,05)$ para o nitrogênio na dose 78 $\mathrm{mg} \mathrm{L}^{-1}$ de potássio, quando uma equação de segundo grau representou este efeito e dentro da dose de $390 \mathrm{mg} \mathrm{L}^{-1}$ de potássio quando obedeceu a uma equação de primeiro grau. O ponto de máxima concentração de cálcio nas lâminas novas da braquiária ocorreu com $279 \mathrm{mg} \mathrm{L}^{-1}$ de nitrogênio na solução (Figura 32). Na dose de potássio $234 \mathrm{mg} \mathrm{L}^{-1}$ não foi verificada significância 
$(P>0,05)$ para as doses de nitrogênio, na concentração de cálcio nas lâminas de folhas novas da braquiária.

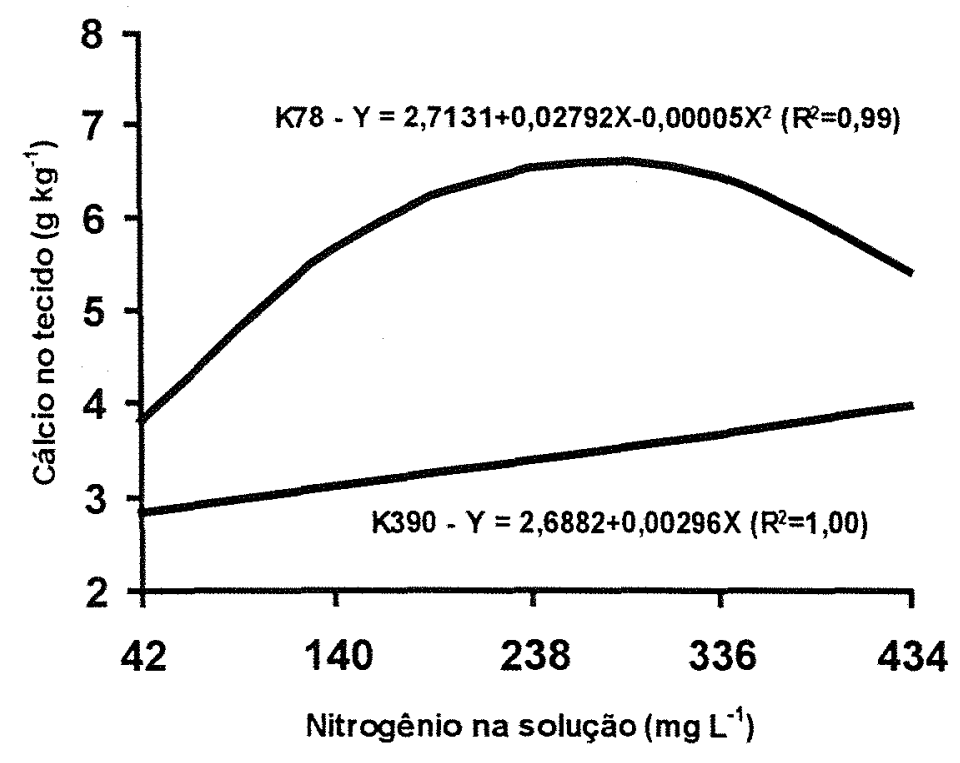

Figura 32 - Concentração de cálcio nas lâminas de folhas novas, no segundo corte da braquiária decumbens, em função das doses de nitrogênio dentro das doses de potássio 78 e $390 \mathrm{mg} \mathrm{L}^{-1}$ na solução nutritiva.

No material do segundo corte, observou-se significância $(P<0,05)$ para as doses de potássio dentro da dose de nitrogênio $42 \mathrm{mg} \mathrm{L}^{-1}$ e $(P<0,01)$ para o potássio nas doses 140 e $238 \mathrm{mg} \mathrm{L}^{-1}$ de nitrogênio na solução, obedecendo em qualquer destes casos a modelo linear (Figura 33). Dentro das doses de nitrogênio de 336 e $434 \mathrm{mg} \mathrm{L}^{-1}$ não foram verificadas significâncias $(P>0,05)$ para as doses de potássio na solução. 


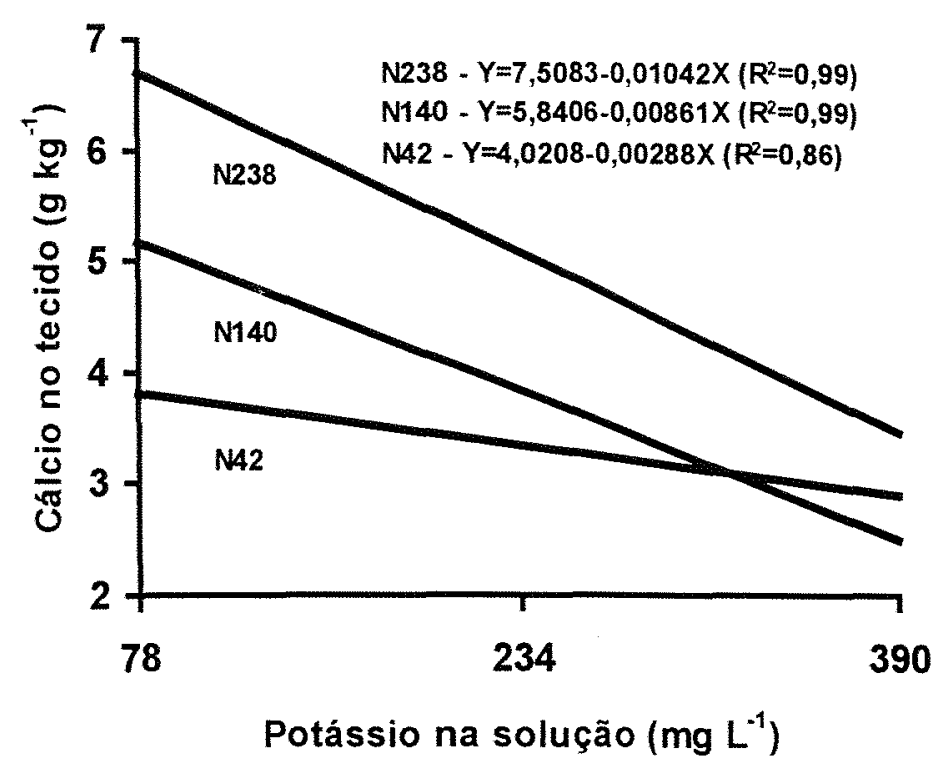

Figura 33 - Concentração de cálcio nas lâminas de folhas novas, no segundo corte, da braquiária decumbens, em função das doses de potássio dentro de cada dose de nitrogênio na solução nutritiva.

Pode-se observar que nas doses 42,120 e $238 \mathrm{mg} \mathrm{L}^{-1}$ de nitrogênio e na maior dose de potássio: ( $390 \mathrm{mg} \mathrm{L}^{-1}$ ) foi obtida a mais baixa concentração de cálcio nas lâminas de folhas novas, e esses valores são relativamente baixos para a nutrição da planta.

Gallo et al. (1974) verificaram nas gramineas estudadas que a maior freqüência de teores de cálcio ocorreu na faixa de 4 a $8 \mathrm{~g} \mathrm{~kg}^{-1}$ e observaram que a concentração de cálcio nas forrageiras foi maior do que duas vezes a concentração de fósforo. Mesa et al. (1989) constataram teores de cálcio na ordem de 9,3 $\mathrm{g} \mathrm{kg}^{-1}$ em bermuda (Cynodon dactylon L. cv. 68) e $13,4 \mathrm{~g} \mathrm{~kg}^{-1} \mathrm{em}$ rhodes (Chloris gayana Kunth. $\mathrm{Cv}$. callide) com potássio em $400 \mathrm{~kg} \mathrm{ha}^{-1}$.

Botrel et al. (1990) encontraram que, independentemente da dose de nitrogênio, as concentrações de cálcio em espécies de Brachiaria foram da ordem de 1,3 a 2,8 $\mathrm{g} \mathrm{kg}^{-1}$. Na Brachiaria brizantha BRA-000337 e na Brachiaria humidícola BRA-000213 o teor de cálcio foi mais baixo $\left(1,3\right.$ a $\left.1,8 \mathrm{~g} \mathrm{~kg}^{-1}\right)$ do que os valores obtidos na Brachiaria ruziziensis BRA-000272 e Brachiaria 
decumbens BRA-000141 que foram da ordem de 2,6 a $2,8 \mathrm{~g} \mathrm{~kg}^{-1}$, respectivamente.

França \& Haag (1985) observaram teores de cálcio em folhas novas de capim-Tobiatã (Panicum maximum Jacq.) da ordem de $6,7 \mathrm{~g} \mathrm{~kg}^{-1}$, enquanto Monteiro et al. (1995) constataram teores de cálcio na matéria seca da parte aérea de Brachiaria brizantha $\mathrm{cv}$. Marandu, da ordem de $8,5 \mathrm{~g} \mathrm{~kg}^{-1}$ no tratamento completo e de $0,9 \mathrm{~g} \mathrm{~kg}^{-1}$ na ausência desse nutriente.

Faquin et al. (1995) obtiveram teores de cálcio na parte aérea da Brachiaria brizantha $\mathrm{cv}$. Marandu, no segundo corte, de $6,4 \mathrm{~g} \mathrm{~kg}^{-1}$ de cálcio no tratamento completo, enquanto na omissão de cálcio e testemunha foram de 4,0 e $2,6 \mathrm{~g} \mathrm{~kg}^{-1}$, respectivamente. Costa \& Gonçalves (1997) estudando os nutrientes mais limitantes à produção de forragem da Brachiaria decumbens em Rondônia, verificaram teores de cálcio de $15,8 \mathrm{~g} \mathrm{~kg}^{-1}$ no tratamento completo e $5,1 \mathrm{~g} \mathrm{~kg}^{-1}$ na testemunha.

Martim (1997) observou que a concentração de cálcio na parte aérea dos capins Tifton 85 e Coastcross 1, no segundo e terceiro crescimentos, diminuiram com o incremento das doses de potássio. Esse comportamento também foi mencionado por Mesa et al. (1989) e Cripps et al. (1989).

\subsubsection{Magnésio}

A análise de variância da concentração de magnésio nas lâminas de folhas novas da forrageira revelou não ter sido significativa $(P>0,05)$ a interação entre doses de nitrogênio e doses de potássio, no primeiro corte, enquanto constatou-se significância $(P<0,01)$ para a interação entre as doses desses nutrientes, no segundo corte.

No estudo dos efeitos das doses de nitrogênio observou-se que a concentração de magnésio nas lâminas de folhas novas da braquiária, no primeiro crescimento foi representada segundo um modelo linear (Figura 34). 
As doses de potássio não tiveram significância $(P>0,05)$ em tal concentração, nas lâminas de folhas coletadas no primeiro crescimento.

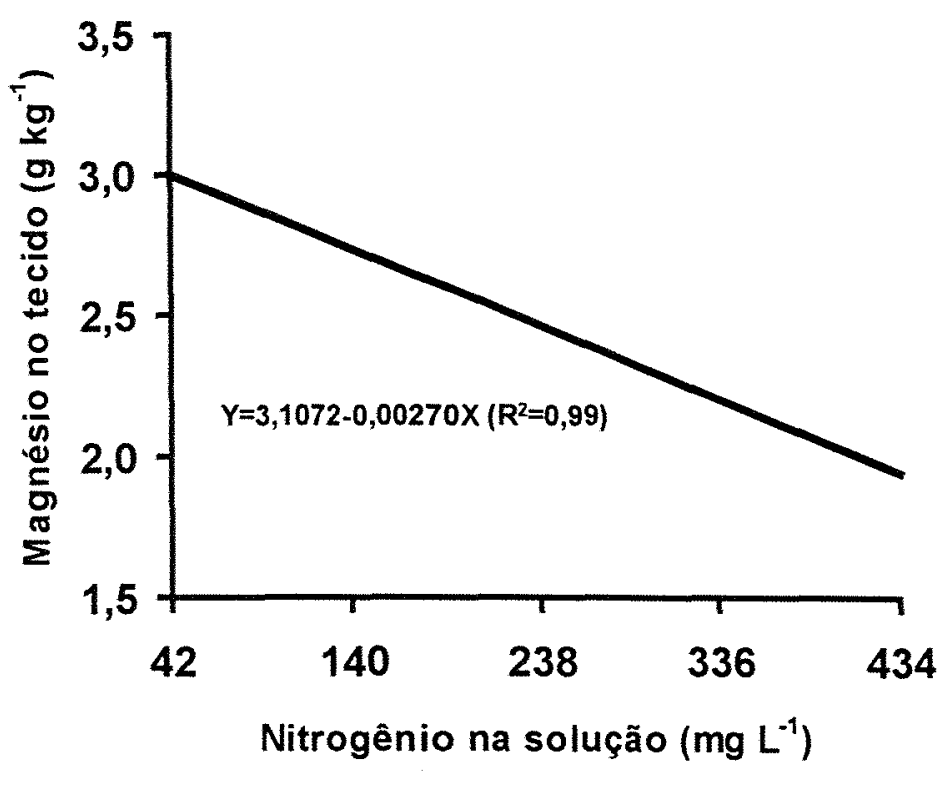

Figura 34 - Concentração de magnésio nas lâminas de folhas novas, no primeiro corte, da braquiária decumbens, em função das doses de nitrogênio na solução nutritiva.

Para 0 segundo corte verificou-se significância $(P<0,01)$ para as doses de nitrogênio dentro da dose de $78 \mathrm{mg} \mathrm{L}^{-1}$ de potássio, situação em que uma equação de primeiro grau representou esse efeito. Na dose de $234 \mathrm{mg} \mathrm{L}^{-1}$ de potássio constatou-se significância $(P<0,01)$ para o nitrogênio e o efeito foi representado por uma equação de segundo grau. $\mathrm{Na}$ dose de $390 \mathrm{mg} \mathrm{L}^{-1}$ de potássio observou-se significância $(P<0,05)$ para o nitrogênio e esse efeito na concentração de magnésio nas lâminas de folhas novas ajustou-se a uma equação de segundo grau. A máxima concentração de magnésio nas lâminas de folhas novas seria obtida com nitrogênio na solução em $183 \mathrm{mg} \mathrm{L}^{-1}$ (Figura 35). 
No desdobramento da interação para potássio dentro de cada dose de nitrogênio, no segundo corte, verificou-se efeito significativo $(P<0,05)$ para 0 potássio dentro das doses de nitrogênio de $42 \mathrm{mg} \mathrm{L}^{-1}$ e $140 \mathrm{mg} \mathrm{L}^{-1}(P<0,01)$, e esses efeitos foram representados em ambas situações por modelo linear (Figura 36). Nas doses 238, 336 e $434 \mathrm{mg} \mathrm{N} \mathrm{L}^{-1}$ não se verificou significância $(P>0,05)$ para as doses de potássio, no que se refere à concentração de magnésio no tecido vegetal da braquiária.

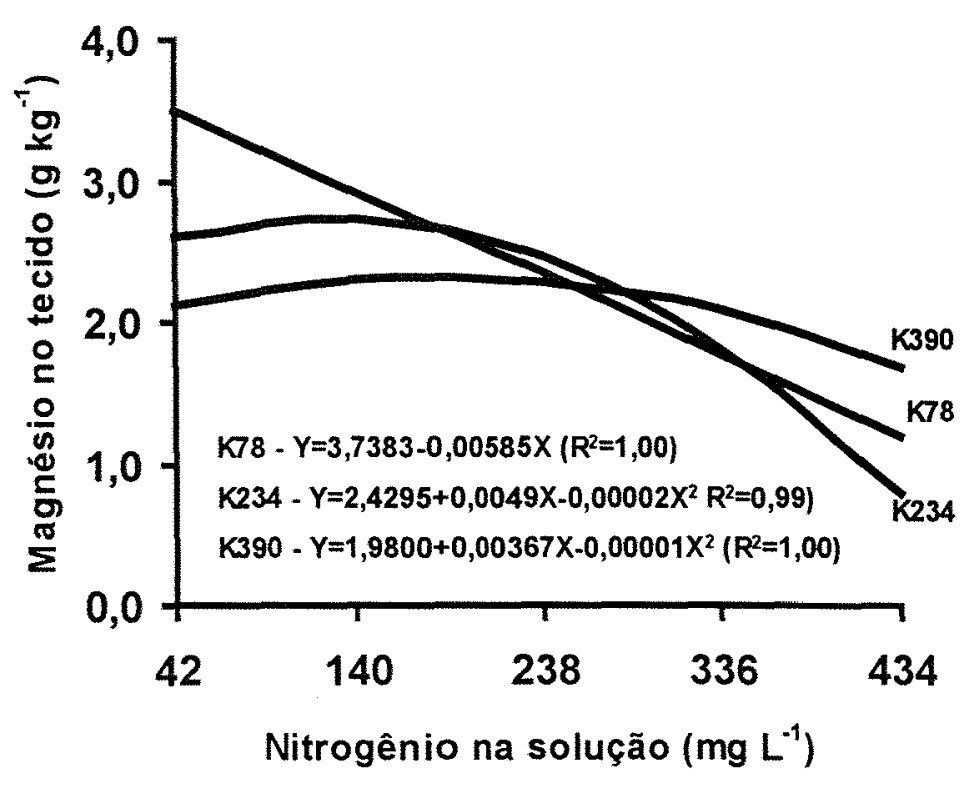

Figura 35 - Concentração de magnésio nas lâminas de folhas novas, no segundo corte, da braquiária decumbens, em função das doses de nitrogênio dentro das doses de potássio na solução nutritiva 


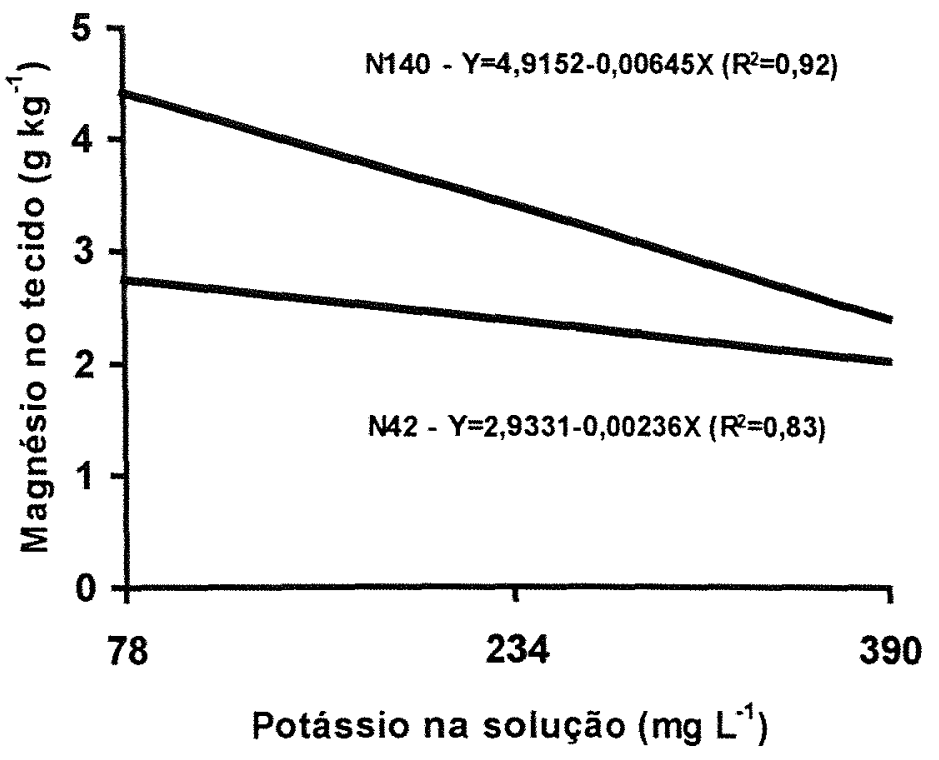

Figura 36 - Concentração de magnésio nas lâminas de folhas novas, no segundo corte, da braquiária decumbens, em função das doses de potássio dentro das doses de nitrogênio na solução nutritiva

Malavolta (1981) preconizou que a relação potássio:magnésio no substrato é importante, uma vez que o excesso do primeiro causa menor absorção do segundo pelas plantas.

Mesa et al. (1989) constataram em bermuda 68 e rhodes callide que a concentração de magnésio foi incrementada até a dose de potássio de $150 \mathrm{~kg} \mathrm{ha}^{-1}$, ao mesmo tempo em que relataram ter sido o teor de magnésio diminuído à medida em que foi incrementada a dose de potássio no solo.

Martim et al. (1997) verificaram nos capins Coastcross 1 e Tifton 85 que a concentração de magnésio na parte aérea do terceiro corte decresceu linearmente com o incremento na adubação potássica, mas essa concentração foi tanto mais baixa quanto menos nitrogênio foi utilizada na adubação. Martim (1997), no terceiro crescimento dos capins, verificou que o teor de magnésio aumentou linearmente $(P<0,01)$ com $o$ incremento nas doses de nitrogênio, mas apenas para os níveis mais elevados de potássio ( 75 e $\left.135 \mathrm{~kg} \mathrm{ha}^{-1}\right)$. Constatou ainda nos capins teores de magnésio de $3,0 \mathrm{~g} \mathrm{~kg}^{-1}$. 
Gallo et al. (1974) encontraram que cerca de $62 \%$ das pastagens analisadas apresentaram teores de magnésio na faixa de 1,2 a $2,6 \mathrm{~g} \mathrm{~kg}^{-1}$, enquanto que em $63 \%$ das forrageiras a concentração foi mais elevada que $2,6 \mathrm{~g} \mathrm{~kg}^{-1}$. Por sua vez, França et al. (1985) encontraram teores de magnésio nas folhas novas de capim-Tobiatã (Panicum maximum Jacq.) da ordem de 7,6 $\mathrm{g} \mathrm{kg}^{-1}$.

Kappel et al. (1985) nos capins bermudagrass (Cynodon dactylon cv. Alicia) e bahiagrass (Cynodon dactylon cv. Argentine) adubados com 342 $\mathrm{kg} \mathrm{ha}^{-1}$ de $\mathrm{N}, 189 \mathrm{~kg} \mathrm{ha}^{-1}$ de $\mathrm{P}_{2} \mathrm{O}_{5}$ e $180 \mathrm{~kg} \mathrm{ha}^{-1}$ de $\mathrm{K}_{2} \mathrm{O}$ obtiveram teores de magnésio de 2,2 e $3,2 \mathrm{~g} \mathrm{~kg}^{-1}$, respectivamente. Faquin et al. (1995a) constataram na parte aérea da Brachiaria brizantha cv. Marandu, no segundo corte, teores de magnésio na faixa de 1,4 a $5,5 \mathrm{~g} \mathrm{~kg}^{-1}$ no tratamento completo $e$ de $0,7 \mathrm{~g} \mathrm{~kg}^{-1}$ quando foi omitido o magnésio.

Monteiro et al. (1995) verificaram na parte aérea de Brachiaria brizantha $\mathrm{cv}$. Marandu, aos 50 dias após o transplante, teor de magnésio de 3,5 $\mathrm{g} \mathrm{kg}^{-1}$ no tratamento completo, enquanto no tratamento que não foi suprido esse nutriente obtiveram $0,4 \mathrm{~g} \mathrm{~kg}^{-1}$. Costa et al. (1997) observaram na Brachiaria decumbens teores de magnésio da ordem de $3,4 \mathrm{~g} \mathrm{~kg}^{-1}$ na parte aérea das plantas no tratamento completo e de $2,3 \mathrm{~g} \mathrm{~kg}^{-1}$ naquelas da testemunha.

\subsubsection{Enxofre}

A concentração de enxofre nas lâminas de folhas novas apresentou efeito significativo para a interação entre doses de nitrogênio e doses de potássio, no primeiro $(P<0,05)$ e no segundo corte $(P<0,01)$.

No primeiro crescimento foi significativo $(P<0,01) \circ$ efeito das doses de nitrogênio dentro da dose $234 \mathrm{mg} \mathrm{L}^{-1}$ de potássio, sendo a resposta ao nitrogênio ajustada a uma equação de segundo grau (Figura 37). Nas doses de 
potássio de 78 e $390 \mathrm{mg} \mathrm{L}^{-1}$, no primeiro crescimento, não se obteve significância $(P>0,05)$ para o efeito do nitrogênio em termos da concentração de enxofre no tecido das lâminas de folhas novas.

No material colhido no segundo corte verificou-se significância $(\mathrm{P}<0,01)$ para $\mathrm{o}$ nitrogênio dentro das três doses de potássio, sendo representado este efeito nas doses de potássio de 78 e $234 \mathrm{mg} \mathrm{L}^{-1}$ por modelo quadrático (Figura 38), enquanto que na dose de potássio de $390 \mathrm{mg} \mathrm{L}^{-1}$ esse efeito obedeceu a um modelo linear (Figura 39). A máxima concentração de enxofre no tecido das lâminas de folhas novas ocorreria em $306 \mathrm{mg} \mathrm{L}^{-1}$ de nitrogênio com potássio na dose de $78 \mathrm{mg} \mathrm{L}^{-1}$ na solução nutritiva.

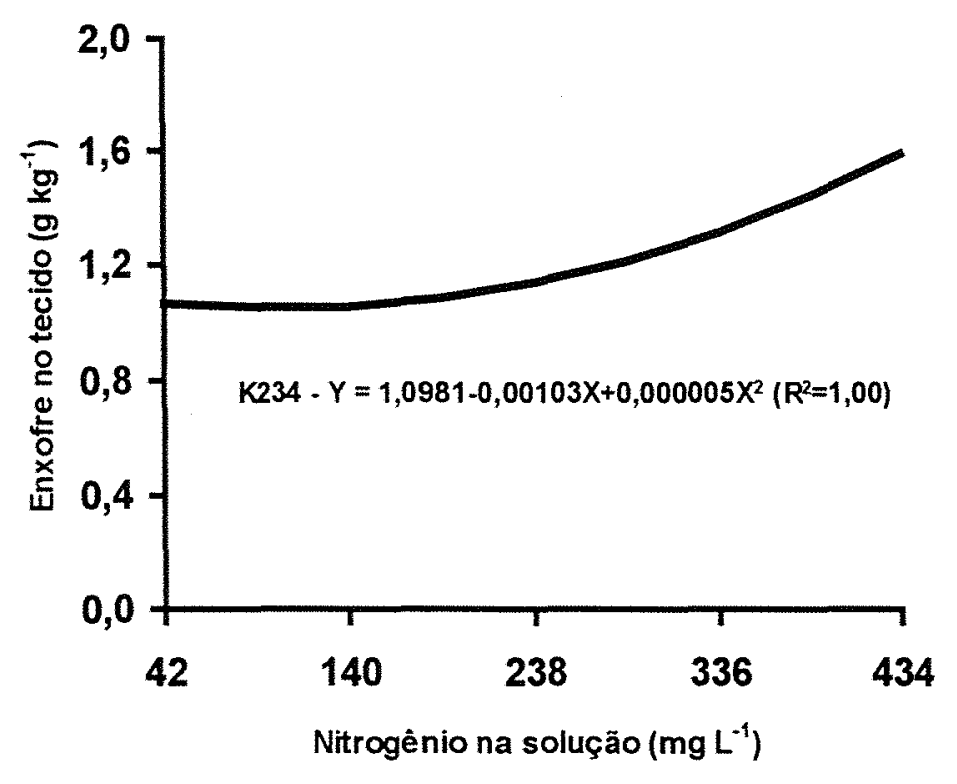

Figura 37 - Concentração de enxofre no tecido das lâminas de folhas novas no primeiro corte, da braquiária decumbens, em função das doses de nitrogênio dentro da dose $234 \mathrm{mg} \mathrm{L}^{-1}$ de potássio na solução nutritiva. 


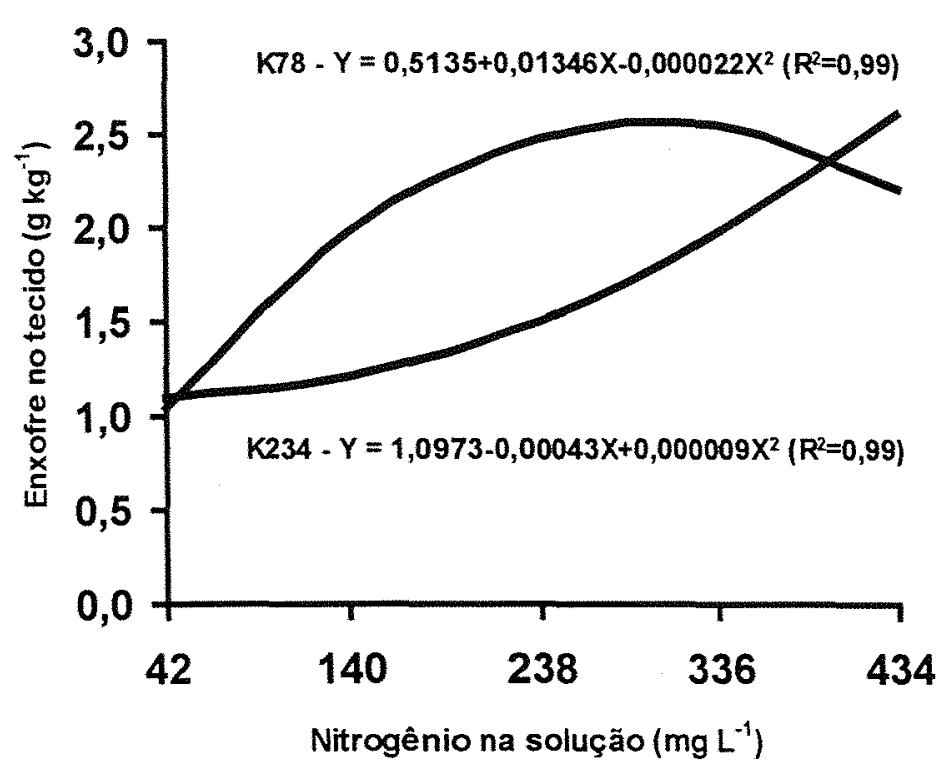

Figura 38 - Concentração de enxofre no tecido das lâminas de folhas novas, no segundo corte da braquiária decumbens, em função das doses de nitrogênio dentro de duas doses de potássio na solução nutritiva.

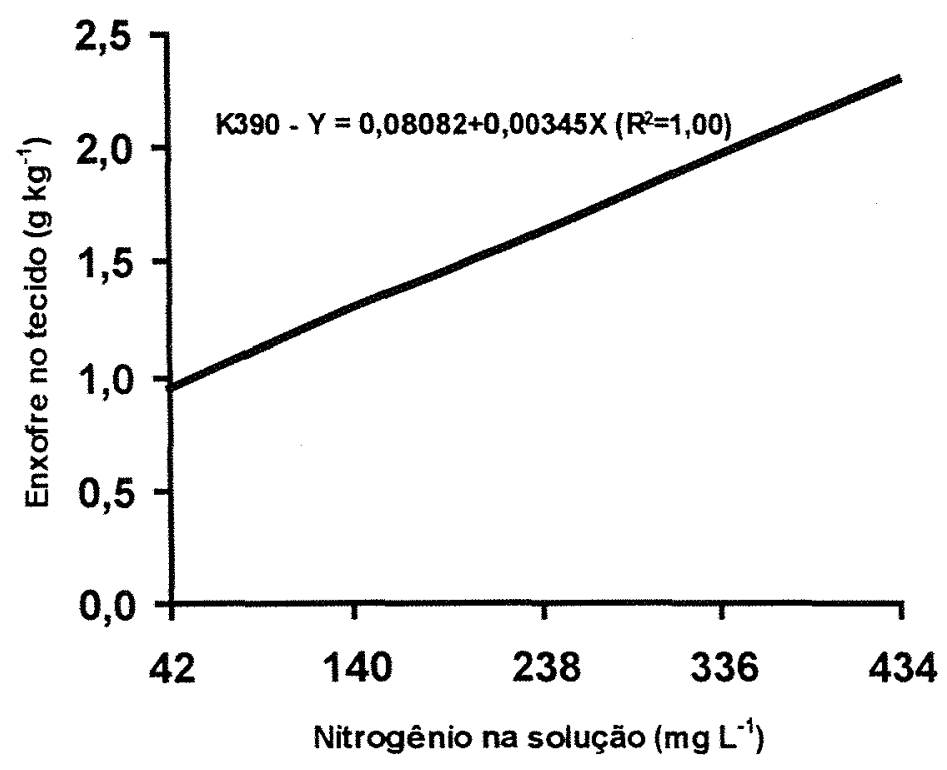

Figura 39 - Concentração de enxofre no tecido das lâminas de folhas novas no segundo corte da braquiária decumbens, em função das doses de nitrogênio dentro da dose de potássio $390 \mathrm{mg} \mathrm{L}^{-1}$ na solução nutritiva. 
Dentro de cada dose de nitrogênio constatou-se, no primeiro corte, que a concentração de enxofre no tecido da braquiária não foi influenciada significativamente $(P>0,05)$ pelas doses de potássio na solução.

No segundo corte, verificou-se significância $(P<0,01)$ para as doses de potássio dentro da dose de nitrogênio de $238 \mathrm{mg} \mathrm{L}^{-1}$ na solução nutritiva e para $(P<0,05)$ as doses de potássio dentro da dose de nitrogênio de $434 \mathrm{mg} \mathrm{L}^{-1}$. Em ambos casos o melhor ajuste se deu a modelo quadrático (Figura 40). O ponto de máxima concentração de enxofre nas lâminas de folhas novas, na dose de nitrogênio de $434 \mathrm{mg} \mathrm{L}^{-1}$, ocorreu com potássio na solução em $205 \mathrm{mg} \mathrm{L}^{-1}$. Nesta dose de potássio também se obteve a maior produção de matéria seca nas lâminas de folhas novas. Nas doses de nitrogênio de 42, 140 e $336 \mathrm{mg} \mathrm{L}^{-1}$ não se verificou variação significativa $(P>0,05)$ na concentração de enxofre no tecido da braquiária, em função das doses de potássio na solução.

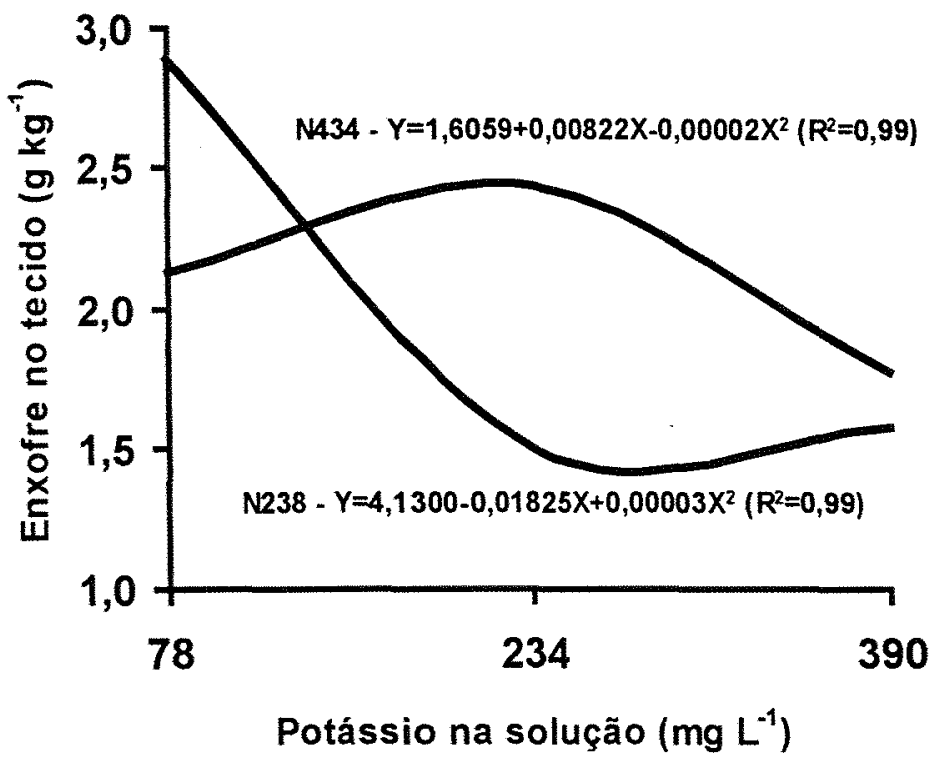

Figura 40 - Concentração de enxofre no tecido das lâminas de folhas novas no segundo corte, da braquiária decumbens, em função das doses de potássio dentro de duas doses de nitrogênio na solução nutritiva. 
Gallo et al. (1974) observaram a maior freqüência dos teores de enxofre em $65 \%$ dos casos analisados, quando essa concentração estava na faixa de 1 a $3 \mathrm{~g} \mathrm{~kg}^{-1}$ em 122 gramíneas. Santos (1997) verificou que a máxima concentração de enxofre nas lâminas de folhas novas foi de $1,6 \mathrm{~g} \mathrm{~kg}^{-1}$, no primeiro corte. Faquin et al. (1995b) nas lâminas de folhas novas do capimbraquiária, cultivado num Latossolo Vermelho-Escuro com doses de 0,50,100, 200 e $400 \mathrm{mg} \mathrm{kg}^{-1}$ potássio e $0,20,40,80$ e $120 \mathrm{mg} \mathrm{kg}^{-1}$ de enxofre, encontraram teores de enxofre entre 0,9 e $1,2 \mathrm{~g} \mathrm{~kg}^{-1}$. Monteiro et al. (1995) constataram na matéria seca da parte aérea de Brachiaria brizantha cv. Marandu, cultivada em solução nutritiva, aos 50 dias após o transplante, teores de enxofre no tratamento completo de $2,4 \mathrm{~g} \mathrm{~kg}^{-1}$ enquanto no tratamento com omissão desse nutriente foi de $1,0 \mathrm{~g} \mathrm{~kg}^{-1}$. 


\section{CONCLUSÕES}

- Doses de nitrogênio e de potássio interagiram significativa e principalmente no primeiro crescimento do capim-braquiária;

- A interação entre doses de nitrogênio e de potássio foi significativa no perfilhamento e na produção de matéria seca das lâminas de folhas novas, de colmos mais bainhas e da parte aérea da forrageira;

- Doses de nitrogênio e de potássio mostraram não se interagir em termos de produção de matéria seca de folhas não-expandidas, de folhas velhas, de inflorescências e de raízes da gramínea;

- Nas laminas de folhas novas coletadas nos cortes do capim, as doses de nitrogênio e de potássio tiveram interação significativa para as concentrações de nitrogênio e enxofre e não significativa para a concentração de potássio;

- A maximização da produção do capim-braquiária ocorreu em dose de nitrogênio muito mais elevada que a normalmente presente na solução nutritiva de Sarruge. 


\section{REFERÊNCIAS BIBLIOGRÁFICAS}

ABREU, J.B.R. Níveis de nitrogênio e proporções de nitrato e amônio afetando produção, atividade da redutase do nitrato e composição de três gramíneas forrageiras. Piracicaba, 1994. 109p. Dissertação (Mestrado) - Escola Superior de Agricultura "Luiz de Queiroz", Universidade de São Paulo.

ALCÂNTARA, P.B. Origem das braquiárias e suas características morfológicas de interesse forrageiro. In: ENCONTRO PARA DISCUSSÃO SOBRE CAPINS DO GÊNERO Brachiaria, 1., Nova Odessa, 1986. Anais. Nova Odessa: Instituto de Zootecnia, 1987, p.1-18.

ALVIM, M.J.; BOTREL, M.A.; VERNEQUE, R.S. et al. Aplicação de nitrogênio em acessos de Brachiaria. 1. Efeito sobre a produção de matéria seca. Pasturas Tropicales, v.12, n.2, p.2-6, 1990.

ARRUDA, N.G.; CANTARUTTI, R.B.; MOREIRA, E.M. Tratamentos físicoquímicos e fertilização na recuperação de pastagens de Brachiaria decumbens em solos de tabuleiro. Pasturas Tropicales, v.9, n.3, p.36-39, 1987.

BATAGLIA, O.C. Determinação indireta de enxofre em plantas por espectrofotometria de absorção atômica. Ciência e Cultura, v.28, n.6, p. $672-675,1976$.

BIANCHINE, D.; MECELIS, N.R.; WERNER, J.C. Época de colheita e adubação nitrogenada na produção de sementes de capim-Ramirez. Boletim de Indústria Animal, v.44, n.2, p. 349-358, 1987. 
BLASER, R.E.; HAMMES Jr, R.C.; FONTENOT, J. P. et al. Forage animal management systems. Blackbsurg: Virginia Agricultural Experimental Station, 1986. 90 p. (Bulletin, 86-7).

BOGDAN, A. V. Tropical pasture and fodder plants. New York: Longman, 1977. 455p.

BOTREL, M.A.; ALVIM, M.J.; MARTINS, C.E. Aplicação de nitrogênio em acessos de Brachiaria. 2. Efeito sobre os teores de proteína bruta e minerais. Pasturas Tropicales, v.12, n.2, p. 7-10, 1990.

BREDON, R.N.; HORRELL, C.R. The chemical composition and nutritive value of some common grasses in Uganda. II. The comparison of chemical composition and nutritive value of grasses throughout the year, with special reference to the later stage of growth. Tropical Agriculture, v.39, n.1, p.13-17, 1962.

BROCKINGTON, N. R.; ASPIOLEA, J.L.; RIOS, C. et al. Respuesta de cuatro gramíneas a la fertilización nitrogenada bajo condiciones de secano. II Composición química. Ciencia y Técnica en la Agricultura, Suelos y Agroquímica, v.11, n.3, p. 17-24, 1988.

BUFARAH, G.; PEDREIRA, J.V.S.; MATTOS, H.B. Adaptação de plantas forrageiras no litoral sul do Estado de São Paulo. Boletim de Indústria Animal, v. 39, n.2, p. 81-92, 1982. 
CARVALHO, D.D.de; PAULINO, V,T.; LUCENA, M.A.C. et al. Fontes e doses de nitrogênio na produção, teor de proteína bruta e perfilhamento do capimcoastcross-1 [Cynodon dactylon (L.) Pers. Cv. coastcross-1] (compact disc). In: CONGRESSO BRASILEIRO DE CIENNCIA DO SOLO, 26., Rio de Janeiro, 1997. Resumos. Rio de Janeiro: Sociedade Brasileira de Ciência do Solo,1997.

CARVALHO, M.M.; MARTINS, C.E.; VERNEQUE, R.S. et al. Respostas de uma espécie de Brachiaria à fertilização com nitrogênio e potássio em um solo ácido. Revista Brasileira de Ciência do Solo, v.15, n.2, p.195-200, 1991.

CORREAA, B.D. Doses de nitrogênio e de magnésio afetando aspectos produtivos e bioquímicos dos capins Colonião, Tanzânia-1 e Vencedor. Piracicaba. 1996. 76p. Dissertação (Mestrado) - Escola Superior de Agricultura "Luiz de Queiroz", Universidade de São Paulo.

CORRÊA, B.D.; SANTOS, A.R.; MATTOS, W.T. et al. Rendimento de matéria seca, concentração de nitrogênio e perfilhamento do capim-Vencedor (Panicum maximum) sob doses de nitrogênio. (compact disc) In: CONGRESSO LATINOAMERICANO DE CIÊNCIA DO SOLO, 13, Águas de Lindóia, 1996. Resumos. Águas de Lindóia, Sociedade Brasileira de Ciência do Solo, 1996.

CORRÊA, B.D.; MONTEIRO, F.A. Doses de nitrogênio e de magnésio afetando produção de matéria seca e perfilhamento nos capins Colonião, Tanzânia-1 e Vencedor (compact disc). In: CONGRESSO BRASILEIRO DE CIÊNCIA DO SOLO, 26., Rio de Janeiro, 1997. Resumos. Rio de Janeiro: Sociedade Brasileira de Ciência do Solo, 1997. 
CORSI, M. Effects of nitrogen rates and harvesting intervals on dry matter production, tillering and quality of the tropical grass Panicum maximum Jacq. Ames, 1984. 125p. Thesis (Ph. D) - The Ohio State University.

COSTA, N. L; GONÇALVES, C.A. Nutrientes limitantes ao crescimento de Brachiaria decumbens em Rondônia (compact disc). In: CONGRESSO BRASILEIRO DE CIÊNCIA DO SOLO, 26., Rio de Janeiro, 1997. Resumos. Rio de Janeiro:Sociedade Brasileira de Ciência do Solo, 1997.

DAVIES, A. Leaf tissue remaining after cutting and regrowth in perennial ryegrass. Journal of Agricultural Science, v.82, p.165-172, 1974.

DIAS, P.F.; ROCHA, G.P.; OLIVEIRA, A. I.G. et al. Produtividade e qualidade de gramíneas forrageiras tropicais sob adubação nitrogenada no final do período das águas. Pesquisa Agropecuária Brasileira, v.33, n.7, p. 11911197, 1998.

EPSTEIN, E. Nutrição mineral das plantas: princípios e perspectivas. São Paulo: EDUSP, 1975. 341p.

FAQUIN, V.; CURI, N.; MARQUES, J.J.G.S.M. et al. Limitações nutricionais para gramíneas forrageiras em Cambissolo álico da microregião Campos da Mantiqueira-MG, Brasil. 2. Nutrição em macro e micronutrientes. Pasturas Tropicales, v.17, n.3, p.17-22, 1995a. 
FAQUIN, V.; HOFFMANN, C.R.; EVANGELISTA, A.R. et al. O potássio e o enxofre no crescimento da braquiária e do colonião em amostras de um Latossolo da região Noroeste do Paraná. Revista Brasileira de Ciência do Solo, v. 19, n.3, p. 87-94, 1995b.

FAVORETTO, V.; RODRIGUES, I.R.A.; TUPINAMBÁ, L.F. Estudo do nitrogênio na produção e composição bromatológica do capim-colonião e seus aspectos econômicos. Científica, v.9, n.2, p.295-300, 1988.

FERNANDES, F.M.; ISEPON, O.J.; NASCIMENTO, V.M. Resposta de Brachiaria decumbens Stapf. a niveis de N, P e K em solo originalmente coberto por vegetação de cerrado. Científica, v.13, n.1/2, p.89-97, 1985.

FERRARI NETO J. Limitações nutricionais para o colonião (Panicum maximum Jacq.) e braquiária (Brachiaria decumbens Stapf.) em Latossolo da região Noroeste do Estado do Paraná. Lavras, 1991. 126p. Dissertação (Mestrado) - Escola Superior de Agricultura de Lavras.

FRANÇA. A.F.S.; HAAG, H.P. Nutrição mineral de gramíneas tropicais. I. Carências nutricionais de capim-Tobiatã (Panicum maximum Jacq.). Anais da Escola Superior de Agricultura "Luiz de Queiroz", v.62, p. 83-95, 1985.

GALLO, J.R.; HIROCE, R.; BATAGLIA, O.C. et al. Composição química inorgânica de forrageiras do Estado de São Paulo. Boletim de Indústria Animal, v. 31, n.1, p. 115-137, 1974. 
GAVILLON, O.; THEREZA QUADROS, A. Variações no teor de potássio nas pastagens nativas do Rio Grande do Sul. Porto Alegre: Secretaria da Agricultura do Rio Grande do Sul, Departamento de Produção Animal, 1969. (Boletim Técnico, 14).

GOMIDE, J.A. Estudo em pequenas parcelas sobre a fertilização do capim gordura (Melinis minutiflora, Pal. de Beauv). Revista Ceres. Viçosa, v.13, n. 75, p.165-181, 1966.

GOMIDE, J.A. Aspectos biológicos e econômicos da adubação de pastagens. In: ECOSSISTEMA DE PASTAGENS, 1., Jaboticabal, 1989. Anais. Jaboticabal: FUNESP, 1989. p. 237-270.

GOMIDE, J.A.; NOLLER, C.H.; MOTT, G.O. et al. Mineral composition of six tropical grasses as influenced by plant age and nitrogen fertilization. Agronomy Journal, v. 61, n. 1, p. 120-123, 1969.

HARDING, W.A.T.; GROF, B. Effect of fertilizer nitrogen on yield, nitrogen content and animal productivity of Brachiaria decumbens $\mathrm{cv}$. Basilisk on the wet tropical coast of North Queensland. Queensland Journal of Agricultural and Animal Sciences, v.35, n.1, p.11-21, 1978.

HERLING, V.R.; ZANETTI, M.A.; GOMIDE, C.A. et al. Influência de niveis de adubações nitrogenada e potássica e estádios de crescimento sobre o capim-estrela (Setária anceps Stapf. Ex. Massey cv. Kazangula). 1. Produção de matéria seca e fisiologia de perfilhamento. Revista da Sociedade Brasileira de Zootecnica, v.20, n.6, p.561-571, 1991. 
HERNANDEZ, M.; CARDENAS, M. Respuesta del pasto estrella jamaicano a niveles de NPK en un suelo ferralítico cuarcítico. Pastos y Forrajes, v.13, p.273-277, 1990.

HOFFMANN, C.R. Nutrição mineral e crescimento de Brachiaria e do Coloniāo, sob influência das aplicações de nitrogênio, fósforo, potássio e enxofre em Latossolo da região noroeste do Paraná. Lavras, 1992. 204p. Dissertação (Mestrado) - Escola Superior de Agricultura de Lavras.

KAPPEL, L.C.; MORGAN, E.B.; KILGORE, L. et al. Seasonal change of mineral content of southern forages. Journal of Dairy Science, v.68, n.7, p. 1823$1827,1985$.

LANGER, R.H.M. How grasses grow. London: Edward Arnold, 1974. 66p.

MALAVOLTA, E. Elementos de nutrição mineral de plantas. São Paulo: Agronômica Ceres, 1980. 251 p.

MALAVOLTA, E. Manual de química agrícola. São Paulo: Agronômica Ceres, $1981.596 \mathrm{p}$.

MARQUES, J.J.G.S.M.; CURI, N.; FAQUIN, V. et al. Limitações nutricionais para gramíneas forrageiras em Cambissolo álico da microregião Campos de Mantiqueira-MG, Brasil. 1. Produção de matéria seca e perfilhamento. Pasturas Tropicales, v.17, n.3, p. 12-16, 1995.

MARSCHNER, H. Mineral nutrition in higher plants. Berlin: Academic Press, 1995. $674 \mathrm{p}$. 
MARTIM, R.A. Doses de nitrogênio e de potássio para produção e composição dos Capins Coastcross-1 e Tifton 85 em um Latossolo Vermelho-Amarelho. Piracicaba, 1997, 109p. Dissertação (Mestrado) - Escola Superior de Agricultura "Luiz de Queiroz", Universidade de São Paulo.

MARTIM, A.R.; MONTEIRO, F.A.; CARMELLO, Q.A.C. Interação entre nitrogênio e potássio nos capins coastcross 1 e Tifton 85 cultivados num oxissolo (compact disc). In: CONGRESSO BRASILEIRO DE CIÊNCIA DO SOLO, 26., Rio de Janeiro, 1997. Resumos. Rio de Janeiro: Sociedade Brasileira de Ciência do Solo,1997.

MATTOS, W.T.; SILVA, A .A.; SANTOS, A.R. et al. Produção de matéria seca e concentração de potássio em capim-Tanzânia-1 (Panicum maximum) submetido a doses de potássio em solução nutritiva. (compact disc). In: CONGRESSO BRASILEIRO DE CIÊNCIA DO SOLO, 26., Rio de Janeiro, 1997. Resumos. Rio de Janeiro: Sociedade Brasileira de Ciência do Solo, 1997.

MATTOS, W.T. Diagnose nutricional de potássio em duas espécies de braquiária. Piracicaba, 1997. 74p. Tese (Mestrado) - Escola Superior de Agricultura "Luiz de Queiroz", Universidade de São Paulo.

MAZZANTI, A.; LEMAIRE, G.; GASTAL, F. The effect of nitrogen fertilization upon the herbage production of tall fescue swards continuously grazed with sheep. 1. Herbage growth dynamics. Grass and Forage Science, v.49, p.111-120, 1994. 
MECELIS, N.; OLIVEIRA, P.R.P. Componentes da produção de sementes de Brachiaria humidicola: Efeito da adubação nitrogenada e épocas de colheita. Zootecnia, v. 22, n.1, p. 57-71, 1984.

MENGEL, K.; KIRKBY, E.A. Principles of plant nutrition. 4.ed. Bern: International Potash Institute, 1987.687p.

MESA, A.R.; MENDOZA, F.; AVILA, V. Rendimiento, composición química y niveles críticos de potasio en cuatro gramíneas tropicales. Pastos y Forrajes, v.12, n.1, p. 43-51, 1989.

MILFORD, R.; MINSON, S.J. The relation between the crude protein content of tropical pasture plants. Journal of the British Grassland Society, v.20, n.3, p.1977-1979,1965.

MITIDIERI, J. Manual de gramíneas e leguminosas para pastos tropicais. 2.ed. São Paulo: Nobel, 1988. 198p.

MONTEIRO, F.A.; WERNER, J.C. Efeitos das adubações nitrogenada $e$ fosfatada em capím colonião, na formação e em pasto estabelecido. Boletim de Indústria Animal, v. 34, p.91-101,1977.

MONTEIRO, F.A; WERNER, J.C. Reciclagem de nutrientes nas pastagens. In: SIMPÓSIO SOBRE MANEJO DE PASTAGEM, 14., Piracicaba, 1997. Anais. Piracicaba: FEALQ, 1987, p. 55-84.

MONTEIRO, F. A .; WERNER, J.C. Reciclagem de nutrientes em pastagens. In: SIMPÓSIO BRASILEIRO DE FORRAGEIRAS, Campinas, 1994. Anais. Campinas: Colégio Brasileiro de Nutrição Animal, 1994, p. 41-65. 
MONTEIRO. F.A.; LIMA, S. A. A.; WERNER, J.C. et al. Adubação potássica em leguminosas e em capim-colonião (Panicum maximum Jacq.) adubado com niveis de nitrogênio ou consorciado com leguminosas. Boletim de Indústria Animal, v.37, n.1, p.127-147, 1980.

MONTEIRO, F.A.; RAMOS, A.K.B.; CARVALHO, D.D. et al. Cultivo de Brachiaria brizantha Stapf. cv. Marandu em solução nutritiva com omissão de macronutrientes. Scientia Agricola, v.52, n.1, p.135-141, 1995.

NABINGER, C. Eficiência do uso de pastagens: disponibilidade e perdas de forragem. In: SIMPÓSIO SOBRE MANEJO DE PASTAGEM, 14., Piracicaba, 1997. Anais. Piracicaba: FEALQ, 1997. p.213-251.

NOVOA, R.; LOOMIS, R.S. Nitrogen and plant production. Plant and Soil, The Hague, v. 58, n. 1-3, p. 177-204, 1981.

PEDREIRA, J.V.S.; MATTOS, H.B. Crescimento estacional de vinte e cinco espécies ou variedades de capins. Boletim de Indústria Animal, v.38, n.2, p. $117-143,1981$.

PIETROSEMOLI, S.; FARIA, L.G.; VILLALOBOS, N. Respuesta del pasto Brachiaria brizantha a la fertilización nitrogenada. Revista de la Facultad de Agronomía. Universidad del Zulia, v. 13, n.5, p. 551-560, 1996.

PREMAZZI, L.M. Saturação por bases como critério para recomendação de calagem em cinco forrageiras tropicais. Piracicaba, 1991. 215p. Dissertação (Mestrado) - Escola Superior de Agricultura "Luiz de Queiroz", Universidade de São Paulo. 
RAIJ, B. van. Fertilidade do solo e adubação. São Paulo: Agronômica Ceres; Associação Brasileira para Pesquisa da Potassa e do Fosfato. 1991. 343 p.

RAIJ, B. van; QUAGGIO, J.A. Disponibilidade de potássio em solos para Capim-braquiária cultivado em solos. Bragantia, v. 43, n.2, p. 531-539, 1984.

ROBINSON, D.L. Potassium nutrition of forage grasses. In: MUNSON R.D., (Ed.) Potassium in agriculture. Madison: Wisconsin, 1985. p. 895-914.

ROCHA, G. L. da. Situação das pastagens no Estado de São Paulo, pastagens naturais e cultivadas. In: CURSO DE MANEJO DE PASTAGENS, 1., Nova Odessa, 1985. Anais. Nova Odessa: Instituto de Zootecnia, 1985. p.124

SANZONOWICZ, C. Recomendação e prática de adubação e calagem na região centro-oeste do Brasil. In: CALAGEM E ADUBAÇÃO DE PASTAGENS, Nova Odessa, 1985. Anais. Piracicaba: Associação Brasileira para a Pesquisa de Potassa e do Fosfato, 1986. p.309-336.

SANTOS, A. R. dos. Diagnose nutricional e respostas do capim-braquiária submetido a doses de nitrogênio e enxofre. Piracicaba, 1997. 115p. Tese (Doutorado) - Escola Superior de Agricultura "Luiz de Queiroz", Universidade de São Paulo. 
SANTOS, A.R.; CORREAA, B.D.; MONTEIRO, F.A. Efeito de niveis de nitrogênio sobre $o$ rendimento de matéria seca, teor de nitrogênio $e$ perfilhamento em Panicum maximum cultivar Vencedor. In: CONGRESSO BRASILEIRO DE CIÊNCIA DO SOLO, 25., Viçosa. 1995. Resumos. Viçosa: Sociedade Brasileira de Ciência do Solo, 1995. p. 741-742.

SARRUGE, J.R. Soluções nutritivas. Summa Phytopathologica. v.1, n.3, p. 231-233, 1975.

SARRUGE, J.R.; HAAG, H.P. Análises químicas em plantas Piracicaba: ESALQ, Departamento de Química, 1974. 56 p.

SAS INSTITUTE CORPORATION. Propriety software release 6.11. Cary, 1996.

SILVA, A.A.; MATTOS, W.T.; MONTEIRO, F.A. Respostas de capim-Tanzânia1 (Panicum maximum) a níveis de potássio em solução nutritiva. In: CONGRESSO BRASILEIRO DE CIÊNCIA DO SOLO, 25, Viçosa, 1995, Resumos. Viçosa: Sociedade Brasileira de Ciência do Solo, 1995. p.1046-1047.

SOARES FILHO, C.V.; MONTEIRO, F.A.; CORSI, M. Recuperação de pastagens degradadas de Brachiaria decumbens. 1. Efeito de diferentes tratamentos de fertilização e manejo. Pasturas Tropicales, v.14, n.2, p.1-6, 1992.

TOLEDO, J.M. Pasturas en trópico húmedo: perspectiva global. In: SIMPÓSIO DO TRÓPICO ÚMIDO, 1., Belém, 1984. Resumos. Belém: EMBRAPA, CPATU, 1984. p.315-316. 
USHERWOOD, N.R. Interação do potássio com outros ions. In: SIMPÓsIO SOBRE POTÁSSIO NA AGRICULTURA BRASILEIRA, Londrina, 1982. Anais. Piracicaba: Instituto de Potassa \& Fosfato, Instituto Internacional de Potassa; Londrina: Fundação IAPAR, 1982. p. 227-247.

VICENTE-CHANDLER, J. Intensive grassland management in Puerto Rico. Revista da Sociedade Brasileira de Zootecnica, v.2, n.1, p.173-215, 1973.

VICENTE-CHANDLER, J.; PEARSON, R.W.; ABRUÑA, F. et al. Potassium fertilization of intensively managed grasses under humid tropical conditions. Agronomy Journal. v.54, n.5, p.450-453,1962.

WERNER, J.C. Adubação de pastagens Nova Odessa: Instituto de Zootecnia, 1986. 49 p. (IZ. Boletim Técnico, 18).

WERNER, J.C.; HAAG, H.P. Estudos sobre a nutrição mineral de alguns capins tropicais. Boletim de Indústria Animal, v.29, n.1, p.191-245, 1972.

WERNER, J.C.; QUAGLIATO, J.L.; MARTINELLI, D. Ensaio de fertilização do colonião com solo do "Noroeste". Boletim de Indústria Animal, v. 24, n. único, p. 159-167, 1967.

WILKINSON, S.R.; LOWREY, R.W. Cycling of mineral nutrients in pasture ecosystems. In: BUTLER, G.W.; BAILEY, R.W., (Ed.) Chemistry and biochemistry of herbage. London: Academic Press, 1973. v.2, p. 247315. 
ZIMMER, A. H.; MACEDO, M. C.; BARCELLOS, A. O. et al. Estabelecimento e recuperação de pastagens de Brachiaria. In: SIMPÓSIO SOBRE MANEJO DE PASTAGEM, 11., Piracicaba, 1994. Anais. Piracicaba: FEALQ, 1994. p. 153-208. 